\title{
Articles
}

\section{TOO MANY TO FAIL: AGAINST COMMUNITY BANK DEREGULATION}

\author{
Jeremy C. Kress \& Matthew C. Turk
}

\begin{abstract}
Since the 2008 financial crisis, policymakers and scholars have fixated on the problem of "too-big-to-fail" banks. This fixation, however, overlooks the historically dominant pattern in banking crises: the contemporaneous failure of many small institutions. We call this blind spot the "too-many-to-fail" problem and document how its neglect has skewed the past decade of financial regulation. In particular, we argue that, for socalled community banks, there has been a pronounced and unjustifiable shift toward deregulation, culminating in sweeping regulatory rollbacks in the Economic Growth, Regulatory Relief, and Consumer Protection Act of 2018 .
\end{abstract}

As this Article demonstrates, this deregulatory trend rests on three myths. First, that community banks do not contribute to systemic risk and were not central to the 2008 crisis. Second, that the Dodd-Frank Act imposed regulatory burdens that threaten the survival of the community bank sector. And third, that community banks cannot remain viable without special subsidies or regulatory advantages. While these claims have gained nearuniversal acceptance among legal scholars and policymakers, none of them withstands scrutiny. Contrary to the conventional wisdom, community banks were key participants in the 2008 crisis, were not uniquely burdened by postcrisis reforms, and continue to thrive economically.

Dispelling these myths about the community bank sector leads to the conclusion that diligent oversight of community banks is necessary to preserve financial stability. Accordingly, this Article recommends a reversal of the community bank deregulatory trend and proposes affirmative reforms, including enhanced supervision and macroprudential stress tests, that would help mitigate systemic risks in the community bank sector.

AUTHORS-Jeremy Kress is an Assistant Professor of Business Law, University of Michigan Ross School of Business. Kress was previously an attorney in the Federal Reserve Board's Legal Division. Matthew Turk is an Assistant Professor of Business Law, Indiana University - Kelley School of 
Business. For helpful comments and conversations, we thank Mehrsa Baradaran, Michael Barr, Vince Buccola, Brian Feinstein, Gregg Gelzinis, Heidi Mandanis Schooner, Graham Steele, Arthur Wilmarth, and David Zaring. We would also like to thank participants at the Academy of Legal Studies in Business Annual Conference, the Big Ten Business Law Scholars Seminar, and the National Business Law Scholars Conference. For excellent research assistance, we thank Shreya Fadia.

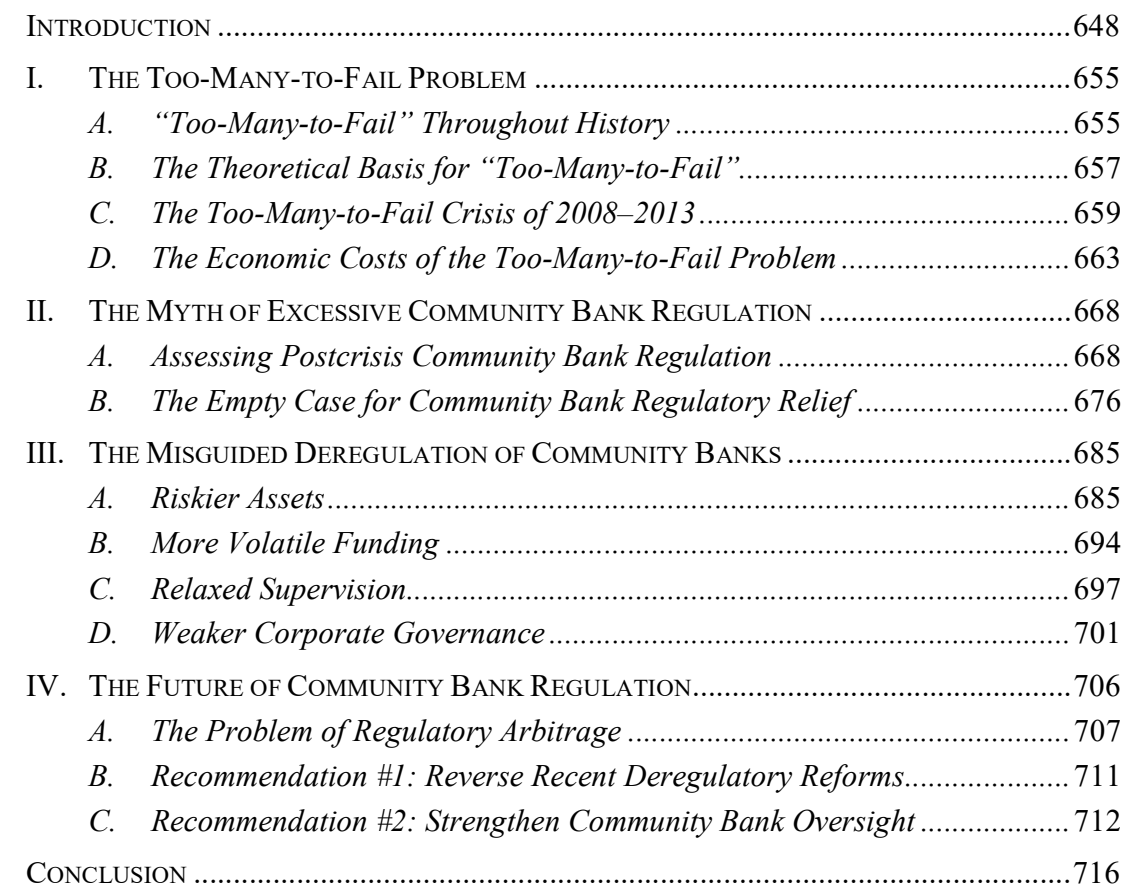

\section{INTRODUCTION}

If there was one consensus following the 2008 financial crisis, it was that "too-big-to-fail" banks were to blame for the market crash. ${ }^{1}$ Commentators and policymakers lambasted Lehman Brothers, Bear Stearns, AIG, Goldman Sachs, and other perceived culprits for misconduct and

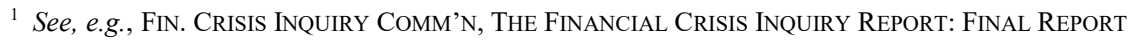
of the National COMmission on the CAUSES OF tHe FinanCial AND ECONOMIC CRisis IN THE UNITED STATES, at xviii (2011) ("We conclude dramatic failures of corporate governance and risk management at many systemically important financial institutions were a key cause of this crisis.").
} 
excessive risk-taking. ${ }^{2}$ As a result, the Dodd-Frank Wall Street Reform and Consumer Protection Act (Dodd-Frank) and other postcrisis regulatory reforms cracked down on the biggest banks to prevent them from cratering the economy again. ${ }^{3}$

This shared understanding of the 2008 crash as a too-big-to-fail crisis reflected an equally broad assumption: that small banks were not the problem. So-called community banks were perceived to be innocent bystanders, overrun by market turmoil caused by much larger financial institutions. ${ }^{4}$ Policymakers and legal scholars alike presumed that community banks - which were far removed from Wall Street's financial engineering - could not be the source of systemic risk. ${ }^{5}$

Community banks have long been sympathetic figures in financial regulatory circles. Generally speaking, community banks are deposit-taking institutions with less than $\$ 10$ billion in assets that focus on traditional financial products like commercial real estate, home mortgage, small business, and agriculture loans. ${ }^{6}$ Reasoning that such firms pose little risk,

\footnotetext{
${ }^{2}$ One columnist famously called Goldman Sachs "a great vampire squid wrapped around the face of humanity, relentlessly jamming its blood funnel into anything that smells like money." Matt Taibbi, The Great American Bubble Machine, Rolling STONE (Apr. 5, 2010, 7:58 PM), https://www.rollingstone .com/politics/politics-news/the-great-american-bubble-machine-195229/ [https://perma.cc/QKS7T5UG].

${ }^{3}$ The preamble to Dodd-Frank states that it is "[a]n Act ... to end 'too big to fail." Dodd-Frank Wall Street Reform and Consumer Protection Act (Dodd-Frank Act), Pub. L. No. 111-203, 124 Stat. 1376, 1376 (2010).

${ }^{4}$ See, e.g., Michelle Fox, Most Banks Were Victims of 2008 Crisis: Kovacevich, CNBC (Sept. 15, 2014, 5:21 PM), https://www.cnbc.com/2014/09/15/most-banks-were-victims-of-2008-crisiskovacevich.html [https://perma.cc/76WT-X69X] ("The 7,000 mainstream banks did not have any serious problems. They didn't do the bad things. They were victims of the crisis that occurred because of the 20 perpetrators[.]" (internal quotation marks omitted) (quoting Wells Fargo chief executive officer Richard Kovacevich)).

${ }^{5}$ See, e.g., U.S. Dep't of the Treasury, A Financial System That Creates Economic OPPORTUNITIES: BANKS AND CREDIT UNIONS 40 (2017) [hereinafter TREASURY BANKING REPORT], https://www.treasury.gov/press-center/press-releases/Documents/A\%20Financial\%20System.pdf [https://perma.cc/KY5S-TS8B] ("[C]ommunity banks... do not present risks to the financial system ....."); see also Tanya D. Marsh, Reforming the Regulation of Community Banks After DoddFrank, 90 IND. L.J. 179, 184 (2015) (“[C]ommunity banks did not cause the 2008 financial crisis.").

${ }^{6}$ The term "community bank" has been used as both a colloquial label for small banks in general and as a more technical legal term of art. Historically, regulators considered a depository institution to be a community bank if it had less than $\$ 1$ billion in assets. See, e.g., OfF. OF THE COMPTROLLER OF THE CURRENCY, COMPTROller's HANDBOOK: COMMUNITY BANK SUPERVISION 1 (2010) (“Community banks are generally defined as banks with less than $\$ 1$ billion in total assets...."). More recently, however, regulators increased this threshold to $\$ 10$ billion. See, e.g., OfF. OF THE COMPTROLLER OF THE CURRENCY, COMPTROLLER's HANDBOOK: COMMUNITY BANK SUPERVISION 1 (2018) (“Generally, banks with assets of $\$ 10$ billion or less are characterized as community banks."). For research purposes, the Federal Deposit Insurance Corporation (FDIC) adopts a more nuanced view, treating a depository institution as a community bank if it has less than $\$ 10$ billion in assets, engages in traditional banking
} 
policymakers have frequently granted community banks special regulatory treatment. ${ }^{7}$ By the late 2010s, however, many observers concluded that Dodd-Frank had inadvertently handicapped community banks, burdening them with unwarranted legal requirements and compliance costs. ${ }^{8}$ Across the political spectrum, policymakers agreed that community banks needed relief from Dodd-Frank in order to remain competitive. ${ }^{9}$

This dominant narrative has now culminated in sweeping deregulation of the community bank sector. In 2018, Congress passed the Economic Growth, Regulatory Relief, and Consumer Protection Act (EGRRCPA) with bipartisan support. ${ }^{10}$ The EGRRCPA and related rollbacks by the federal banking agencies eased capital requirements, loosened liquidity rules, and relaxed supervisory oversight of community banks. ${ }^{11}$ The largest community bank trade association celebrated these reforms for providing "relief from excessive and unnecessary regulatory burdens." ${ }^{12}$ Regulators likewise agreed

activities, and operates in a limited geography. See FDIC, Community BANKING STUDY, at 1-1 to -3 (2012) [hereinafter FDIC COMMUNITY BANKING STUDY]. Most scholars agree that the essential characteristics of a community bank are small asset size, a simple balance sheet, and limited geographic scope. See, e.g., Marshall Lux \& Robert Greene, The State and Fate of Community Banking 3-4 (Harvard Kennedy Sch. Mossavar-Rahmani Ctr. for Bus. \& Gov't, Working Paper No. 37, 2015), https://www.hks.harvard.edu/sites/default/files/centers/mrcbg/files/Final_State_and_Fate_Lux_ Greene.pdf [https://perma.cc/4T35-3QEZ].

${ }^{7}$ For example, under the Federal Reserve's Small Bank Holding Company and Savings and Loan Holding Company Policy Statement, community bank holding companies are exempt from certain regulatory capital requirements. See 12 C.F.R. § 225, app. C (2017).

${ }^{8}$ See, e.g., Marshall Lux \& Robert Greene, Opinion, Dodd-Frank Is Hurting Community Banks, N.Y. TiMES (Apr. 14, 2016, 3:20 AM), https://www.nytimes.com/roomfordebate/2016/04/14/has-dodd-frankeliminated-the-dangers-in-the-banking-system/dodd-frank-is-hurting-community-banks

[https://perma.cc/D8VY-RSCH]; Rob Nichols, Yes, Community Banks Are Struggling Under DoddFrank, POLITICO (Sept. 6, 2016, 3:18 PM), https://www.politico.com/agenda/story/2016/09/communitybanks-dodd-frank-000197 [https://perma.cc/9GAJ-HZSW].

9 See Scott Heitkamp, Opinion, Political Foes Agree: Small Banks Pounded by Dodd-Frank, HiLL (June 27, 2017, 6:20 PM), https://thehill.com/blogs/pundits-blog/finance/339693-helping-small-banksis-something-we-can-all-agree-on [https://perma.cc/J52P-HFXY].

${ }^{10}$ Economic Growth, Regulatory Relief, and Consumer Protection Act (EGRRCPA), Pub. L. No. 115-174, 132 Stat. 1296 (2018); see also Aaron Klein, Bipartisanship in Banking Is Back, BROOKINGS (Mar. 4, 2018), https://www.brookings.edu/research/bipartisanship-in-banking-is-back/ [https:// perma.cc/UT22-WADE] (noting that the EGRRCPA was supported by "a group of moderate Democrats [and] most[,] if not all[,] Republicans").

11 See infra Part III.

12 Press Release, Indep. Cmty. Bankers of Am., ICBA Supports Senate Community Bank Regulatory Relief Agreement (Nov. 13, 2017), https://www.icba.org/news/news-details-results/2017/11/13/ICBASupports-Senate-Community-Bank-Regulatory-Relief-Agreement [https://perma.cc/T9RP-FL55]. 
that the EGRRCPA would help small banks "meet the financial service needs of their consumers and businesses." 13

This Article challenges the conventional wisdom that led to this comprehensive deregulation. It is the first legal scholarship to scrutinize the widely accepted justifications for easing regulatory burdens on community banks. ${ }^{14}$ As the Article demonstrates, the leading rationales for rolling back community bank safeguards are each deeply flawed.

First, contrary to popular belief, community banks can propagate systemic risk. When community banks fail, they do not collapse in isolation. Rather, community banks tend to fail en masse due to their highly correlated balance sheets and funding strategies. ${ }^{15}$ And when many community banks fail simultaneously, small businesses, homeowners, and local communities lose access to needed financial services, further damaging the economy. ${ }^{16}$ This dynamic, which we call the "too-many-to-fail" problem, has occurred in every banking crisis in U.S. history, up to and including the 2008 crash. ${ }^{17}$

Second, Dodd-Frank and other post-financial crisis reforms did not uniquely burden community banks. To the contrary, policymakers exempted community banks from the most significant Dodd-Frank rules. ${ }^{18}$ While some "one-size-fits-all" postcrisis rules do apply to community banks, regulators minimized the burden on smaller firms by setting easily achievable standards and publishing special compliance guides. Moreover, several provisions in Dodd-Frank introduced generous subsidies for community banks that more than offset compliance costs attributable to the most onerous postcrisis rules. ${ }^{19}$ Thus, the consensus view that postcrisis reforms unduly burdened community banks is seriously mistaken.

${ }^{13}$ Press Release, Off. of the Comptroller of the Currency, Comptroller of the Currency Lauds Progress Toward Meaningful Regulatory Reform (Dec. 5, 2017), https://www.occ.treas.gov/newsissuances/news-releases/2017/nr-occ-2017-145.html [https://perma.cc/457T-DWRR].

${ }^{14}$ One outlier that takes a similar approach is work by Professor Heidi Mandanis Schooner, who has questioned the popular notion of community bank deregulation. See Heidi Mandanis Schooner, Regulating Angels, 50 GA. L. REV. 143, 160-61 (2015). Although Schooner advocates for strong community bank oversight, her essay does not squarely rebut common arguments for community bank regulatory relief. Separately, an excellent student note has disputed the view that community banks face unnecessary compliance costs. See Merric R. Kaufman, Note, Too Small to Succeed?: An Analysis of the Minimal Undue Regulatory Burdens Facing Community Banks in the Post Dodd-Frank Regulatory Environment, and How to Further Minimize Their Burdens, 37 REV. BANKING \& Fin. L. 445, 458-68 (2018) (arguing that compliance costs associated with Dodd-Frank did not themselves cause the decline of community banks).

${ }^{15}$ See infra Sections I.A, I.B.

${ }^{16}$ See infra Section I.D.

${ }^{17}$ See infra Sections I.A, I.C.

${ }^{18}$ See infra Section II.A.1.

19 See infra Section II.A.2. 
Third, community banks do not require regulatory relief to compete with larger financial institutions. In fact, community banks' market share has increased since the financial crisis, and they remain just as profitable as they were before Dodd-Frank. ${ }^{20}$ Proponents of regulatory relief point to a sharp drop in the number of community banks as evidence that Dodd-Frank disproportionately impaired smaller firms, but this too is misleading. On closer examination, the steady decline in the number of community banks predates Dodd-Frank and is more attributable to macroeconomic conditions following the crisis than to excessive regulatory burdens. ${ }^{21}$ The economic case for community bank regulatory relief, therefore, has been vastly overstated.

Despite the limited legal and empirical support for deregulation, these pervasive myths about community banks have gained acceptance not only in policymaking circles, but also in legal scholarship. Of the handful of financial regulatory scholars who have written about community banks, all have endorsed the popular narrative that postcrisis regulation unfairly penalized smaller firms and should be relaxed. ${ }^{22}$ Professor Tanya Marsh, for example, asserts that Dodd-Frank "puts community banks at a competitive disadvantage as compared with their larger, more complex competitors." ${ }^{23}$ Even Professor Arthur Wilmarth - typically a proponent of strong financial regulation-has advocated for easing safeguards on community banks. ${ }^{24}$

20 See infra Section II.B.

21 In many cases, the smallest depository institutions have outgrown the community bank designation, while few investors have formed new community banks due to persistently low interest rates. See infra Section II.A.1.

22 See Marsh, supra note 5, at 216-24 (discussing Dodd-Frank's impact on community banks); Arthur E. Wilmarth, Jr., A Two-Tiered System of Regulation Is Needed to Preserve the Viability of Community Banks and Reduce the Risks of Megabanks, 2015 MICH. ST. L. REV. 249, 282-88 (2015) (asserting that Dodd-Frank imposes a heavy compliance burden on community banks); see also Bryce W. Newell, The Centralization of the Banking Industry: Dodd-Frank's Impact on Community Banks and the Need for Both Regulatory Relief and an Overhaul of the Current Framework, 15 DEPAUL BuS. \& COM. L.J. 1, 1516 (2016) (surveying evidence of community banks' compliance costs post-Dodd-Frank); Gregory Butz, Comment, Treating Apples Like Oranges: The Benefit of Exempting Community Banks from the Volcker Rule, 6 TEX. A\&M L. REV. 453, 465-67 (2019) (discussing the Volcker Rule's effect on community banks); Alan J. Wilson, Note, There Goes the Neighborhood: Regulating Away the Community BankAn Analysis of the Costs of Current Regulations on Community Banks, 116 W. VA. L. REV. 463, 480-85 (2013) (contending that Dodd-Frank increases the regulatory burden on community banks). Even Professor Schooner, who supports strong prudential regulation of community banks, concedes that community bank regulatory relief proposals "are worthy of serious and careful consideration." Schooner, supra note 14 , at $158-59$.

23 Marsh, supra note 5, at 179.

${ }^{24}$ Professor Wilmarth opposed provisions in the EGRRCPA that deregulated mid-size banks. See Arthur E. Wilmarth, Jr., Raising SIFI Threshold to \$250B Ignores Lessons of Past Crises, AM. BANKER (Feb. 7, 2018, 9:30 AM), https:/www.americanbanker.com/opinion/raising-sifi-threshold-to-250b- 
Thus, legal experts generally support community bank regulatory rollbacks along the lines of the EGRRCPA.

By contrast, this Article argues that the EGRRCPA's community bank deregulation will increase systemic risk in the banking sector. As a result of recent regulatory rollbacks, community banks are more likely to invest in riskier assets and rely on more volatile sources of funding. ${ }^{25}$ Excessive risktaking, meanwhile, will escape supervisory scrutiny because the EGRRCPA curtails regulatory reporting and oversight for these same institutions. ${ }^{26}$ Furthermore, new rules will allow hedge fund and private equity investors to exert greater control over community banks' corporate governance, leading to even more risk-taking. ${ }^{27}$ In combination, therefore, these reforms are likely to increase the fragility of the community bank sector and intensify the toomany-to-fail problem.

A longer-term result of the EGRRCPA will be that riskier financial activities migrate to smaller banks over time as market participants engage in regulatory arbitrage. This conclusion follows from basic economic and financial theory, which predicts that risk-taking tends to shift from wellregulated to less-regulated sectors. ${ }^{28}$ Consistent with the logic of regulatory arbitrage, early evidence suggests that community banks have already begun to absorb a greater share of financial risk as a consequence of Dodd-Frank's emphasis on regulating the too-big-to-fail megabanks. ${ }^{29}$ The EGRRCPA will accelerate this pattern of regulatory arbitrage, as community banks will no longer face risk-based capital requirements, annual supervisory examinations, or limits on volatile funding. Thus, while the consequences of the EGRRCPA might not materialize immediately, this sweeping community bank deregulation will ultimately hasten the next too-many-tofail crisis.

As a response, this Article recommends three policies to combat the looming too-many-to-fail problem. First, policymakers should repeal the EGRRCPA and related deregulatory initiatives. Second, the financial

ignores-lessons-of-past-crises [https://perma.cc/7WGD-9DC6]. Wilmarth, however, has enthusiastically endorsed community bank regulatory relief. See Wilmarth, supra note 22, at 339-42.

${ }^{25}$ See infra Sections III.A, III.B.

${ }^{26}$ See infra Section III.C.

${ }^{27}$ See infra Section III.D

${ }^{28}$ For a seminal academic treatment of regulatory arbitrage, see generally Victor Fleischer, Regulatory Arbitrage, 89 TEX. L. REV. 227 (2010).

${ }^{29}$ See, e.g., Kristle Cortés, Yuliya Demyanyk, Lei Li, Elena Loutskina \& Philip E. Strahan, Stress Tests and Small Business Lending 30-34 (Fed. Rsrv. Bank of Cleveland, Working Paper No. 18-02, 2018) (finding that the market for risky small-business loans has shifted from megabanks to community banks in response to Dodd-Frank stress tests). 
regulatory agencies should use their microprudential supervisory authority to closely scrutinize community banks near the $\$ 10$ billion asset thresholda highly salient regulatory "cliff” where many postcrisis legal restrictions go into effect. Given the opportunity for regulatory arbitrage, risks are likely to "bunch" in banks just below the $\$ 10$ billion threshold, and supervisors should target their oversight accordingly. ${ }^{30}$ Third, the federal banking agencies should perform periodic, sector-wide stress tests of community banks as part of their macroprudential efforts coordinated through Dodd-Frank's Financial Stability Oversight Council (FSOC). ${ }^{31}$ Unlike Dodd-Frank's institutionspecific stress tests for too-big-to-fail banks, sector-wide stress tests would assess the health of the community bank industry as a whole and attempt to identify any common vulnerabilities. Collectively, these reforms would restore strength to the community bank sector and help alleviate the toomany-to-fail problem.

To be clear, our objective is not to stifle community banks with excessive regulation. Instead, these recommendations aim to preserve the long-term viability of the community bank sector. Community banks provide critical financial products and services that too-big-to-fail banks do not. ${ }^{32}$ Unlike big banks, which usually rely on standardized mathematical models when underwriting loans, community banks specialize in "relational" lending - using their familiarity with local customers to extend loans to creditworthy but nontraditional borrowers that rigid underwriting models would not support. ${ }^{33}$ For this reason, community banks are critical to longterm economic growth. Our aim, therefore, is to better align the regulation of this profitable, yet highly cyclical sector with the goal of maximizing lending throughout the business cycle, rather than just in the near term.

The discussion below proceeds as follows. Part I describes the toomany-to-fail phenomenon - its theoretical basis, historical evidence, and underappreciated significance. Part II then critiques the prevailing narrative of excessive community bank regulation. It shows that community banks do not need regulatory relief because Dodd-Frank largely spared smaller firms and, in any event, community banks have flourished since the financial crisis. Part III analyzes the EGRRCPA and related deregulatory initiatives,

\footnotetext{
${ }^{30}$ See infra Section I.B; $c f$. Vladimir Mukharlyamov \& Natasha Sarin, The Impact of the Durbin Amendment on Banks, Merchants, and Consumers 25-27 (Jan. 31, 2019) (unpublished manuscript), https://scholarship.law.upenn.edu/faculty_scholarship/2046/ [https://perma.cc/2K32-YZPZ] (documenting "bunching," or strategic manipulation, of bank-asset sizes around regulatory thresholds).

${ }^{31}$ See infra Section I.C.

${ }^{32}$ For example, despite controlling only $14 \%$ of banking-industry assets, community banks held $46 \%$ of small loans to farms and businesses in 2011. See FDIC COMMUNITY BANKING STUDY, supra note 6, at I.

${ }^{33}$ See id. at 1-1.
} 
detailing how these misguided regulatory rollbacks will undermine the stability of the community bank sector. Finally, Part IV proposes a path forward, suggesting that policymakers should safeguard the financial system by reversing the community bank deregulatory trend and appropriately supervising risks in smaller banks. The Article concludes that such reforms are necessary to mitigate the long-overlooked too-many-to-fail problem.

\section{THE TOO-MANY-TO-FAIL PROBLEM}

Since the 2008 financial crisis, policymakers and scholars have focused on solving the too-big-to-fail problem. To date, however, few have acknowledged an equally serious issue: the simultaneous collapse of numerous small institutions. This Part explains why the too-many-to-fail problem has been the dominant source of systemic risk in U.S. banking history. Section I.A details the role that small banks have played in all previous U.S. banking crises prior to the 2008 crash. Section I.B outlines the theoretical basis for the "too-many-to-fail" phenomenon, by exploring the economic dynamics that cause small banks to propagate financial instability. Section I.C then uses those historical and theoretical analyses to reassess community banks' central but overlooked role in the 2008 crisis. Finally, Section I.D documents the broad economic damage that occurs when many small banks collapse at the same time.

\section{A. "Too-Many-to-Fail” Throughout History}

The fixation on "too-big-to-fail" banks that followed the 2008 financial crisis is understandable in light of the dramatic, headline-grabbing collapse of those institutions. This narrow concern with megabanks, however, threatens to distort U.S. regulatory policy because it obscures one salient fact: every banking crisis in the United States prior to 2008 consisted exclusively of the simultaneous failure of many small banks.

The too-many-to-fail phenomenon has thus been a staple of the U.S. banking sector since the founding of the republic. The nineteenth and early twentieth centuries, when banks were uniformly small, was not an era of financial stability, to say the least. ${ }^{34}$ Among the economically crippling

34 See Charles W. Calomiris \& Stephen H. Haber, Fragile by Design: The Political Origins OF BANKING CRISES AND SCARCE CREDIT 183 (2014) (describing nineteenth-century U.S. banking as a "uniquely unstable system"); GARY B. GorTON, Misunderstanding FinANCIAL CRISES: WhY We Don't See Them Coming 33-38 (2012); Richard S. Grossman, Unsettled Account: The EVOLUTION OF BANKING IN THE INDUSTRIALIZED WORLD SINCE 1800, at 73 (2010) (“[T]he United States [from 1870 to World War I] was characterized by many small, unbranched banks as well as by frequent banking crises."). 
banking crises from this time are the "panics" of 1819, 1837, 1857, 1873, 1893, and $1907 .{ }^{35}$ And that is only a partial list. ${ }^{36}$ This trend of frequent, systemic collapses reached new heights during the Great Depression. President Franklin Roosevelt's attempt to ease the financial panic by declaring a nationwide bank holiday on his first day in office proved to no avail. ${ }^{37}$ Roughly 6,000 banks collapsed in 1933, with a total of 9,000 banks failing by the end of the decade..$^{38}$

After exiting the Great Depression, the financial system entered what has become referred to as its "quiet period," when conditions remained relatively stable from the $1950 \mathrm{~s}$ through the $1970 \mathrm{~s} .{ }^{39}$ That changed, however, with the 1980s savings and loan (S\&L) crisis, which became the second most costly banking collapse in American history behind only the Great Depression. ${ }^{40} \mathrm{It}$, too, involved only small financial institutions. All told, 1,300 firms known as "thrifts" and 3,000 traditional banks failed, at a cost of $\$ 360$ billion to the federal agencies responsible for their resolution. ${ }^{41}$

An obvious caveat to this narrative is that from the Founding to the 1970s, the U.S. financial sector was highly fragmented, to the point that few big banks existed. Yet, by the time of the S\&L crisis in the 1980s, that was no longer the case. Large, globally active banks began to emerge in the early 1970 s. ${ }^{42}$ And as soon as large banks appeared, some failed. The first major institution to collapse was Franklin National Bank in 1974. ${ }^{43}$ In 1984, the term "too big to fail" was coined to describe the downfall of Continental

${ }^{35}$ See Gorton, supra note 34, at 9-24; Charles P. KindLEBERgER \& Robert Z. Aliber, Manias, PANICS, AND CRASHES: A History OF FinANCIAL CRISES 110-12, 131 (5th ed. 2005); Grossman, supra note 34 , at 74 .

${ }^{36}$ Lesser "panics," as mass runs on the banking system are often called, also occurred in 1814, 1825, 1841, 1861, 1864, 1884, 1890, and 1914. See CARMEn M. ReInHART \& KeNNETH S. RogOFF, This Time Is DifFERENT: EIGHT CENTURIES OF FinANCIAL FolLy 389-91, app. 4 (2009).

${ }^{37}$ See Grossman, supra note 34, at 246.

38 See id. at 245-46; CALOMIRIS \& HABER, supra note 34, at 189.

39 See GorTON, supra note 34, at 125-33 (discussing the 1950-1970s quiet period).

40 See Grossman, supra note 34, at 269-73 (discussing the S\&L crisis).

${ }^{41}$ See id. at 272.

${ }^{42}$ See Barry Eichengreen, Exorbitant Privilege: The Rise and Fall of the Dollar and THE FUtURE OF THE INTERNATIONAL MONETARY SYSTEM 49-66 (2011) (detailing the shift from a goldbacked system to the growth of international currencies in the 1960s and '70s); REINHART \& ROGOFF, supra note 36, at 206; Beth A. Simmons, The Internationalization of Capital, in ConTINUITY AND Change In Contemporary CAPITALism 36, 44 (Herbert Kitschelt, Peter Lange, Gary Marks \& John D. Stephens eds., 1999) (describing the internationalization of capital markets in the 1970s).

${ }^{43}$ See Kindleberger \& AliBer, supra note 35, at 267-69; Sam Frizell, Could a 40-Year-Old Bank Collapse Have Saved the U.S. Economy?, TIME (Oct. 8, 2014, 7:00 AM), https://time.com/3479314/ franklin-national-bank/ [https://perma.cc/P6VQ-6BDK]. 
Illinois Bank - at the time, the largest bank failure in U.S. history. ${ }^{44}$ Then, in 1998, the hedge fund Long-Term Capital Management (LTCM) failed in shocking fashion, forcing a final-hour rescue orchestrated by the Federal Reserve Bank of New York. ${ }^{45}$

A common feature of the Franklin National, Continental Illinois, and LTCM episodes was that, despite a few weeks of localized panic and disruption, the consequences for the broader U.S. financial system and economy were negligible. ${ }^{46}$ In other words, even as putatively too-big-to-fail institutions were forming and failing, "too-many-to-fail" was the only systemic risk that actually materialized from the 1970 s to 2008. In sum, even as the U.S. financial sector came to be dominated by diversified financial conglomerates, the too-many-to-fail problem persisted as the primary risk to the financial system.

\section{B. The Theoretical Basis for "Too-Many-to-Fail"}

The recurrence of the "too-many-to-fail" problem throughout U.S. history is unsurprising because it has a strong basis in economic theory. There are three reasons why, still today, community banks are at least as fragile as their larger counterparts. Small banks are especially susceptible to concurrent failures because they have: (1) highly correlated balance sheets, (2) similar funding vulnerabilities, and (3) runnable equity investments.

First, many community bank asset portfolios are relatively undiversified and highly correlated with one another. Small banks typically specialize in niche lending markets - such as commercial real estate, small business, and agricultural loans - which are susceptible to similar economic risks. Larger banks, by contrast, are better able to scale their operations to include multiple lines of businesses, at least some of which are unrelated and therefore exposed to different macroeconomic shocks. ${ }^{47}$ This heterogeneity,

${ }^{44}$ See KindLeBerger \& AliBer, supra note 35, at 98, 219-21, 267-69; Lee Davison, Continental Illinois and "Too Big to Fail," in 1 History OF the Eighties: Lessons FOR the FUtURE: AN EXAMINATION OF THE BANKING CRISES OF THE 1980S AND EARLY 1990S, at 235, 235-36 (1997).

${ }^{45}$ See Tyler Cowen, Bailout of Long-Term Capital: A Bad Precedent?, N.Y. TimES (Dec. 26, 2008), https://www.nytimes.com/2008/12/28/business/economy/28view.html [https://perma.cc/PB7S-5WQG] (discussing the Federal Reserve's rescue of LTCM). See generally RogER LowENSTEIN, WHEN GENIUS FAILED: THE Rise AND FALL OF LONG-TERM CAPITAL MANAGEMENT (2000) (documenting the history of Long-Term Capital Management).

${ }^{46}$ See GorTon, supra note 34, at 9 (stating that the crisis threatened by Continental Illinois "was never observed").

${ }^{47}$ See, e.g., Peter S. Rose, Diversification of the Banking Firm, 24 FIN. Rev. 251, 251 (1989) ("Diversification of banks and bank holding companies into nonbank product lines may reduce the risk to banking returns or cash flows provided appropriate portfolio conditions are satisfied."); William K. Templeton \& Jacobus T. Severiens, The Effect of Nonbank Diversification on Bank Holding Company 
at least in theory, makes individual financial conglomerates, and the large bank sector as a whole, more resilient to economic shocks. ${ }^{48}$ The community bank sector, on the other hand, can easily be wiped out by economic declines that disproportionately affect certain lending markets, because many small banks share similar financial vulnerabilities.

Second, lack of asset diversification among small banks exacerbates the risk of runs on their liabilities. Because banks rely on deposits or other forms of short-term debt, they are prone to funding runs whenever creditors have an inkling that the bank's stability may be compromised. ${ }^{49}$ When assets are less diversified - as in the community bank sector - these creditor panics are more likely. Moreover, since small bank portfolios often look alike, runs can spread rapidly across those institutions due to an "information contagion" process..$^{50}$ Once accountholders in Kansas, for example, hear of bank panics in Ohio and Nebraska, they may rightly believe that the safest course is to withdraw deposits as quickly as possible and ask questions later. There are subtle limits to what federal deposit insurance can do to constrain this dynamic. ${ }^{51}$ Community banks, in sum, are both uniquely susceptible to deposit runs and particularly likely to transmit such distress to other small banks.

Risk, 31 Q.J. Bus. \& ECON. 3, 9 (1992); THE CleAring House, Understanding THE ECONOMics of LARGE BANKS 36 (2011) (describing the benefit of large financial institutions in reducing exposure to individual asset classes); see also Jonathan R. Macey \& James P. Holdcroft, Jr., Failure Is an Option: An Ersatz-Antitrust Approach to Financial Regulation, 120 YALE L.J. 1368, 1411 (2011) (noting that '[1]imiting banks' activities could make banks more risky by reducing their ability to diversify their activities").

48 See CALOMIRIS \& HABER, supra note 34, at 201-02; see also supra note 47.

49 See generally Douglas W. Diamond \& Philip H. Dybvig, Bank Runs, Deposit Insurance, and Liquidity, 91 J. POL. ECON. 401 (1983) (providing the canonical formal model of bank runs, which famously implies that even a stable bank may be subject to a run).

${ }^{50}$ See Viral V. Acharya \& Tanju Yorulmazer, Information Contagion and Bank Herding, $40 \mathrm{~J}$. MONEY, CREDIT \& BANKING 215, 218-21 (2008) (providing a theoretical model of information contagion). See generally Charles Calomiris, Matthew Jaremski \& David C. Wheelock, Interbank Connections, Contagion and Bank Distress in the Great Depression (Fed. Rsrv. Bank of St. Louis, Working Paper No. 2019-001D, 2019), https://research.stlouisfed.org/wp/more/2019-001 [https:// perma.cc/BFM9-7Y54] (discussing information contagion during the Great Depression).

${ }^{51}$ Bank deposits have been insured by the federal government since the Depression-era reforms of 1933. See Banking Act of 1933, Pub. L. No. 73-66, § 12B, 48 Stat. 162, 168 (1933). That guarantee, however, has always been subject to a statutory cap. Since Dodd-Frank, FDIC insurance has covered deposits of up to $\$ 250,000$ per customer, per bank. Dodd-Frank Act, Pub. L. No. 111-203, § 335, 124 Stat. 1376, 1540 (codified as amended at 12 U.S.C. $§ 1821(\mathrm{a})(1)(\mathrm{E})$ ). It is therefore commonplace for businesses or high-net-worth individuals to have larger deposits that are uninsured. Even in the Great Depression, most bank runs were triggered by these groups. See Jonathan D. Rose, Old-Fashioned Deposit Runs 19-23 (Bd. of Governors of the Fed. Rsrv. Sys. Fin. \& Econ. Discussion Series, Working Paper No. 2015-111, 2015). The reason is that larger depositors are usually more sophisticated and have greater incentives to monitor a bank's stability. See id. at 24-25. 
Finally, community banks are vulnerable to runs by not only their creditors but also their equity-holders. Community banks are often small enough to be owned by only a handful of controlling shareholders. When a bank experiences distress, these shareholders may strategically withdraw their investments by declaring special dividends or other capital distributions - the functional equivalent of a "run" on equity. ${ }^{52}$ By withdrawing their equity, community bank investors deplete the bank's capital cushion and leave it even more vulnerable to depreciating asset values. When this process is repeated across many small banks that are experiencing distress simultaneously, runs on equity intensify weaknesses in the community bank sector.

In sum, economic theory provides a straightforward explanation for the United States' recurrent financial crises: small banks are fragile, and when they collapse, they often do so en masse. The theoretical basis of the toomany-to-fail phenomenon lies in the unique vulnerability of each component of community bank balance sheets - assets, debt, and equity. In light of this theoretical grounding, the historical pattern of financial crises in the United States cannot be dismissed as anomalous or outdated trivia. Rather, it is a reminder that the too-many-to-fail problem remains a pressing issue for modern financial regulation.

\section{The Too-Many-to-Fail Crisis of 2008-2013}

Policymakers' recent neglect of the too-many-to-fail problem is not merely a product of historical or theoretical myopia. It also rests on a deeply flawed understanding of the 2008 financial crisis. After the crash, conventional wisdom coalesced around the view that the crisis exclusively involved the big Wall Street banks. ${ }^{53}$ Yet, the factual record makes clear that the collapse of the too-big-to-fail banks was accompanied by a separate, large-scale crisis that swept across small U.S. banks from 2008 to 2013. After the smoke cleared, that initial misconception was never corrected, and the too-many-to-fail crisis of 2008 to 2013 has since languished in obscurity.

The oft-overlooked too-many-to-fail crisis that accompanied the Great Recession was historic in magnitude. The Federal Deposit Insurance Corporation's (FDIC) authoritative account of small-bank performance cites

\footnotetext{
${ }_{52}$ See, e.g., Christopher Henderson, William W. Lang \& William E. Jackson III, Insider Bank Runs: Community Bank Fragility and the Financial Crisis of 2007, at 2-8 (Fed. Rsrv. Bank of Phila., Working Paper No. 15-09, 2015).

${ }_{53}$ See, e.g., TREASURY BANKING REPORT, supra note 5, at 15 (describing the need to reduce the regulatory burden on community banks "in light of the complexity and lack of systemic risk of such financial institutions").
} 
eye-opening figures. ${ }^{54}$ From March 2008 to year-end 2009, the number of distressed banks rose from 90 to $700 .{ }^{55}$ By 2011, it had peaked at 884 , or $12 \%$ of all federally insured depository institutions. ${ }^{56}$ For the 2008 to 2013 period as a whole, 489 banks failed and were resolved by the federal government. ${ }^{57}$ Of those failures, all but nine were community banks..$^{58}$

Moreover, the too-many-to-fail crisis of 2008 to 2013 exhibited strong parallels with both the theoretical intuition and historical record discussed above. The 884 banks that the FDIC declared distressed were not destabilized for 884 different reasons. Rather, they succumbed to a familiar pattern that reflects the underlying dynamics of small banks as a source of systemic risk. Like all preceding too-many-to-fail crises, community banks were wiped out due to a perfect storm of: (1) underdiversified asset portfolios and fragile funding models, which were (2) highly correlated across institutions nationwide, and therefore (3) exposed the community bank sector as a whole to a common macroeconomic shock. ${ }^{59}$

As in previous crises, the 2008 to 2013 too-many-to-fail crisis coincided with a sharp depreciation in community banks' unique asset portfolios. The biggest predictor of a small bank's failure during this time was its exposure to commercial real estate loans and multifamily mortgages - the same mix of assets that destabilized S\&L institutions in the 1980s. ${ }^{60}$ Meanwhile, small banks with relatively large investments in the toxic assets that undermined the Wall Street banks - namely, single-family mortgages and mortgagebacked securities - were more likely to remain stable. ${ }^{61}$

The story for the liability side of small-bank balance sheets was familiar as well. Conventional wisdom holds that, since its introduction in the 1930s,

${ }^{54}$ FDIC, CRISIS AND RESPONSE: AN FDIC HISTORY, 2008-2013 (2017) [hereinafter FDIC REPORT].

${ }^{55} \mathrm{Id}$. at xiv.

${ }^{56} \mathrm{Id}$. at 119 .

${ }^{57}$ Id. at xxxii, 119.

58 Id. at $114-15$.

59 See, e.g., Mark H. Kawa \& Steven VanBever, The Impact of the Financial Crisis on Community Banks: A Conference Summary, CHI. FED LETTER, Mar. 2010 (describing the origins of the 2008-2013 too-many-to-fail crisis).

${ }^{60}$ See Rebel A. Cole \& Lawrence J. White, Déjà Vu All over Again: The Causes of U.S Commercial Bank Failures This Time Around, 42 J. Fin. SERVs. RsCH. 5, 6, 14-15, 26 (2012) (noting the parallel findings from studies of bank failures from the 1985-1992 period); see also Rebel Cole \& Jeffery W. Gunther, Predicting Bank Failures: A Comparison of On- and Off-Site Monitoring Systems, 13 J. Fin. SERVS. RSCH. 103, 106 (1998) (analyzing the sources of S\&L failures); James B. Thomson, Modeling the Bank Regulator's Closure Option: A Two-Step Logit Regression Approach, 6 J. FIN. SERVS. RsCH. 5, 14 17 (1992) (same).

${ }^{61}$ See Cole \& White, supra note 60, at 6, 26. 
federal deposit insurance has protected small banks from runs by creditors. ${ }^{62}$ But as Federal Reserve research has shown, "old-fashioned deposit runs" became widespread during 2008. ${ }^{63}$ Depositors, spooked by the losses community banks experienced on their asset portfolios, rushed to withdraw from their accounts, which in turn forced many community banks to engage in emergency "fire sales" of their assets. ${ }^{64}$ Indeed, the damage from those bank runs was so significant that the FDIC launched the Transaction Account Guarantee Program (TAGP) in October 2008, effectively guaranteeing every deposit of every bank in the United States. ${ }^{65}$ Traditional run dynamics were therefore a key contributor to the small-bank crisis of 2008 .

Finally, community banks also experienced runs on their equity in 2008. During the lead-up to the crisis, when community banks' controlling shareholders saw the writing on the wall, there was a race to strip equity through the issuance of special dividends and other capital distributions. ${ }^{66}$ Runs on equity were most severe at community banks in the weakest condition. ${ }^{67}$ And, predictably, once the equity cushions at these small banks were depleted, they became even more exposed to the collapse of their asset portfolios. ${ }^{68}$

Taken together, these dynamics support a striking conclusion: although small-bank failures during the financial crisis lagged slightly behind the collapse of large financial institutions, which peaked with the failure of Lehman Brothers and AIG in September 2008, the too-many-to-fail crisis was not merely a byproduct of the too-big-to-fail crisis or the sharp economic downturn that followed. Indeed, the assets that proved toxic for the too-bigto-fail banks and the too-many-to-fail banks were different. ${ }^{69}$ Likewise, the

${ }^{6}$ See, e.g., Michael S. BARr, Howell E. JACKSON \& Margaret E. TAHyAR, FinAnCiAL REGULATION: LAW \& POLICY 249 (2d ed. 2018) ("Bank runs have remained virtually nonexistent in the United States since the 1930 s....").

63 See Rose, supra note 51, at 8-9 (discussing deposit outflows from small banks); see also Christopher Martin, Manju Puri \& Alexander Ufier, Deposit Inflows and Outflows in Failing Banks: The Role of Deposit Insurance 10-17 (FDIC, Working Paper No. 2018-02, 2018) (examining how the presence of deposit insurance affected shifts in bank deposits); cf. Hyun Song Shin, Reflections on Northern Rock: The Bank Run That Heralded the Global Financial Crisis, 23 J. ECON PERSPS. 101, 10715 (2009) (describing the run on U.K. bank Northern Rock in late 2007).

${ }^{64}$ A special type of deposit-known as a brokered deposit-experienced especially swift withdrawals. See infra note 232 and accompanying text; infra Section III.B.

65 The TAGP was part of a broader Temporary Liquidity Guarantee Program, which the FDIC rolled out at the time. See FDIC REPORT, supra note 54, at xiii, xvii-xviii.

${ }^{66}$ See Henderson et al., supra note 52, at 13-17.

${ }^{67}$ See id.

${ }^{68} I d$.

69 See supra notes 60-61 and accompanying text. 
run-risks these banks faced were different. Small banks experienced runs by large depositors and concentrated shareholders, while the run on large banks was triggered by an unrelated group of creditors in the "shadow banking" sector. ${ }^{70}$ In addition, small banks were generally unscathed by the counterparty defaults and asset fire sales that led to a domino effect of distress at large, interconnected banks. Although Lehman Brothers' bankruptcy petition led to AIG's failure the next day, no small banks were directly intertwined with either of those institutions or with their other Wall Street peers. ${ }^{71}$ It is not the case, therefore, that community banks were collateral "victims" of the too-big-to-fail crisis of 2008.

Instead, the community bank crisis was caused by a dramatic slowdown in the commercial real estate and construction industries, a development that had already reached historic proportions by $2007 .{ }^{72}$ The downturn in those sectors was so extreme that it would have put many community banks under, regardless of the health of Bear Stearns, Lehman Brothers, AIG, or the shadow banking system that supported them. ${ }^{73}$ In other words, even if the

${ }^{70}$ The shadow banking sector is usually considered to consist of repurchase agreements, asset-backed commercial paper conduits, and money market mutual funds. See generally Daniel Covitz, Nellie Liang \& Gustavo A. Suarez, The Evolution of a Financial Crisis: Collapse of the Asset-Backed Commercial Paper Market, 68 J. FIN. 815 (2013) (explaining asset-backed commercial paper programs and runs by investors); Jeffrey N. Gordon \& Christopher M. Gandia, Money Market Funds Run Risk: Will Floating Net Asset Value Fix the Problem?, 2014 Colum. Bus. L. REV. 313 (discussing money market funds and their role in the financial crisis); Gary Gorton \& Andrew Metrick, Securitized Banking and the Run on Repo, 104 J. FIN. ECON. 425 (2012) (explaining repurchase agreements and their drive in securitizedbanking runs).

${ }^{71}$ See William K. Sjostrom, Jr., The AIG Bailout, 66 WASH. \& LEE. L. REV. 943, 979 (2009) (detailing the relationship between the falls of Lehman Brothers and AIG). With regard to fire sales, large banks were primarily dumping mortgage-backed securities and related instruments, which were not held in substantial amounts by small banks and were not correlated with the failures of small banks that did hold them in substantial amounts. See Cole \& White, supra note 60, at 12-13 ("The loan portfolio variables indicate that failed banks had significantly higher concentrations of Construction \& Development loans and significantly lower concentrations of Residential Single-Family Mortgages and Consumer Loans."); Andrei Schleifer \& Robert Vishny, Fire Sales in Finance and Macroeconomics, 25 J. ECON. PERSPS. 29, 38-41 (2011) (discussing fire sales during the financial crisis).

${ }^{72}$ See generally Steven D. GJerstad \& Vernon L. SMith, Rethinking Housing Bubbles: The Role OF HOUSEHOLD AND BANK BALANCE SHEETS IN MODELING ECONOMIC CYCles (2014) (examining the crash in residential and commercial construction that preceded the financial crisis); see also Adam J. Levitin \& Susan M. Wachter, The Commercial Real Estate Bubble, 3 HARV. Bus. L. ReV. 83, 94, 104 07 (2013) (analyzing the precrisis property bubble with a focus on commercial real estate).

${ }^{73}$ The relevant timeline is detailed in a critical book-length treatment of the financial crisis by Steven Gjerstad and Vernon Smith. As they note, sales of new home units had already collapsed by the end of 2005. By mid-2006, construction of single and multifamily homes, primarily financed by small banks, fell off precipitously as well. See GJERSTAD \& SMITH, supra note 72, at 53-56. Nominal consumer credit outstanding fell $7 \%$ in both 2008 and 2009. The only other postwar years that saw declines were 1975 (1\%) and $1991(1.9 \%)$. See id. at 82. 
too-big-to-fail crisis had never occurred, the recessionary pressures that gained momentum before 2008 would likely have still produced a systemic collapse of the community bank sector between 2008 and 2013. ${ }^{74}$ Moreover, in a counterfactual case where the too-many-to-fail crisis occurred in isolation, the scale of small-bank failures would have been comparable in its severity, ${ }^{75}$ rivaling the 1980 s S\&L crisis and thereby ranking as at least the third-largest banking crisis in modern American history. ${ }^{76}$

\section{The Economic Costs of the Too-Many-to-Fail Problem}

A complete accounting of the too-many-to-fail problem must go beyond the sheer number of banks that failed or experienced distress during a financial crisis. From a policy perspective, the operative issue is not how many banks failed, but at what cost to society. It is well known that damage from the Depression-era bank failures was catastrophic and that the 1980s S\&L crisis imposed remarkable costs as well. The ramifications of the community bank crisis of 2008 to 2013, however, are much less discussed. This Section examines the broader economic costs of too-many-to-fail crises, with a focus on the most recent collapse.

A conservative estimate of the direct costs of community bank failures between 2008 and 2013 puts the immediate damage at nearly $\$ 50$ billion. According to the FDIC, more than $\$ 47$ billion in federal funds was spent in

\footnotetext{
${ }^{74}$ A possible objection on this point is that the recession itself was due to the rise of securitization and other innovations at the too-big-to-fail banks during the 1990s and 2000s. While those practices no doubt played a role, it is equally true that they are neither necessary nor sufficient for a recessionary housing bubble. The Great Depression and the S\&L crisis both featured large shocks to housing markets, in a world where large banks, low-documentation "liar loan" mortgages, mortgage-backed securities, and credit default swaps did not exist. In fact, eleven of the past fourteen recessions in the United States have been preceded by sharp downturns in housing construction and prices. See id. at 10.

${ }^{75}$ Another reason to place less weight on peculiarities of the U.S. home-finance regime is that the coinciding bubble-and-bust cycle in American housing prices was by no means an outlier internationally. Equal or greater fluctuations occurred in most European countries, including Ireland, Spain, Belgium, and France. See Paul Hilbers, Alexander W. Hoffmaister, Angana Banerji \& Haiyan Shi, House Price Developments in Europe: A Comparison 12-13 (IMF Working Paper WP/08/211, 2008) (placing the rise in U.S. housing prices from 2005-2007 at the mid-range of European housing price fluctuations). Nor is the United States an outlier among advanced economies in terms of the rising ratio between private credit accumulation (through mortgages or otherwise) and economic output between 1950 and 2010, which increased at roughly the same rate during those six decades in the United Kingdom, France, and Germany. See Òscar Jordà, Moritz Schularick \& Alan M. Taylor, Macrofinancial History and the New Business Cycle Facts 17 (Nat'l Bureau of Econ. Rsch., Working Paper No. 22743, 2016).

${ }^{76}$ Cf. FDIC REPORT, supra note 54, at 203 (comparing the magnitude of bank failures from 20082013 to that of the S\&L crisis).
} 
the process of resolving the 480 community banks that failed. ${ }^{77}$ As a result, the federal Deposit Insurance Fund (DIF) incurred the steepest loss in its over-eighty-year history. ${ }^{78}$ An additional $\$ 1.5$ billion in direct costs were imposed by distressed or failing banks that relied on the TAGP backstop. ${ }^{79}$ While the federal government ultimately made a profit on its bailouts of Wall Street banks, that was not the case for the emergency funding assistance that it provided to community banks. ${ }^{80}$

These direct costs, however, are dwarfed by the indirect costs of community bank failures. That is because small banks, which specialize in relational lending, provide critical financial products and services that larger banks do not. ${ }^{81}$ As Ben Bernanke famously wrote in his academic research before becoming Federal Reserve Chairman, when small banks across the country crumbled en masse during the Great Depression, many individuals and firms were cut off from the supply of credit that was necessary for normal levels of economic activity. ${ }^{82}$ The same thing happened beginning in 2008. The failure of 480 community banks and the distress of 900 more restricted the supply of financial intermediation to small businesses and entrepreneurs that fuel the real economy in normal times. ${ }^{83}$ Critically, since

77 The cost of resolving all 489 banks that failed between 2008 and 2013 was $\$ 72.5$ billion. See id. at 181-82. The 480 failed community banks accounted for $65 \%$, or $\$ 47.1$ billion, of that total. See id. at $114-15$.

${ }^{78}$ The DIF dropped from an all-time high surplus of $\$ 52.8$ billion in March of 2008 to an all-time low of negative $\$ 20.9$ billion by year-end 2009. Id. at xiv. For a historical timeline of federal deposit insurance, see Historical Timeline, FDIC (Jan. 2, 2014), https://www.fdic.gov/about/ history/timeline/1930s.html [https://perma.cc/AG9V-QBV6].

${ }^{79}$ FDIC REPORT, supra note 54, at 58.

${ }^{80}$ The U.S. Treasury made a profit on the emergency loans it extended to Wall Street banks through the Troubled Asset Relief Program (TARP). See Chris Isidore, U.S. Ends TARP with \$15.3 Billion Profit, CNN Bus. (Dec. 19, 2014, 11:27 AM), https://money.cnn.com/2014/12/19/news/companies/ government-bailouts-end/ [https://perma.cc/5QRZ-W37M]. With respect to TAGP, however, the FDIC absorbed net losses of $\$ 300$ million. FDIC REPORT, supra note 54, at 58. Ironically, therefore, the FDIC's assistance of community banks reflects an exercise in fiscal profligacy compared to that of the government's too-big-to-fail bailouts.

${ }^{81}$ See supra note 33 and accompanying text.

${ }^{82}$ See Ben S. Bernanke, Nonmonetary Effects of the Financial Crisis in the Propagation of the Great Depression, 73 AM. Econ. Rev. 257, 264-65 (1983); Ben S. Bernanke, The Macroeconomics of the Great Depression: A Comparative Approach, 27 J. MONEY, CREDIT, \& BANKING 1, 16-25 (1995). While Bernanke's claim was considered novel at the time, it has since become a standard view among financial historians and economists. See Grossman, supra note 34, at $246 \&$ n. 24 (citing to the related literature); see also GJERSTAD \& SMITH, supra note 72, at 117-18 (discussing the influence of Bernanke's interpretation of the Great Depression); Charles W. Calomiris, Financial Factors in the Great Depression, 7 J. ECON. PERSPS. 61, 70-73 (1993) (same).

${ }^{83}$ See Benjamin R. Mandel \& Joe Seydl, Credit Conditions and Economic Growth: Recent Evidence from US Banks, 147 ECON. LETTERS 63, 64-67 (2016) (detailing the negative loan supply growth following the Great Recession, compared to the quicker recovery of demand); $c f$. Yuying Jin, Mingiin 
community banks serve a unique niche, larger financial institutions were unable to fill the gap in credit provision that materialized when community banks pulled back on issuing new loans ${ }^{84}$ The resulting contraction of credit stalled the exit from the Great Recession, which is often considered among the weaker economic recoveries in modern U.S. history. ${ }^{85}$ Thus, the total economic damage attributable to the too-many-to-fail crisis of 2008 to 2013 extends far beyond the direct monetary costs. ${ }^{86}$

In addition to impairing the economic recovery from the Great Recession, the too-many-to-fail crisis imposed another long-term cost: it exacerbated the moral hazard problem that has always loomed over banking regulation. Moral hazard refers to an incentive that insured parties have to increase their exposure to risks when the downside costs of those risks are borne by the insurer ${ }^{87}$ Federal deposit insurance is the most direct source of the moral hazard problem for banks, but it appears indirectly as well to the extent banks receive ad hoc government bailouts. ${ }^{88}$ Not surprisingly, in light of this moral hazard dynamic, cross-country studies by scholars of comparative financial regulation tend to find a strong association between

Luo \& Chao Wan, Financial Constraints, Macro-Financing Environment and Post-Crisis Recovery of Firms, 55 INT'L REV. ECON. \& FIN. 54, 60-66 (2018) (analyzing the recovery of firms after the global financial crisis and noting that low recovery of firms, particularly those with limited access to external financing during the postcrisis credit crunch, slowed recovery at a macro level).

${ }^{84}$ See Steven G. Craig \& Pauline Hardee, The Impact of Bank Consolidation on Small Business Credit Availability, 31 J. BANKING \& FiN. 1237, 1248-59 (2007) (finding that banking consolidation results in small businesses having less access to credit); Stacy Mitchell, Understanding the Small Business Credit Crunch, INST. FOR LOCAL SELF-ReLIANCE (Apr. 16, 2014), https://ilsr.org/understanding-smallbusiness-credit-crunch/ [https://perma.cc/4ZZK-N6VT]

${ }^{85}$ See GJERSTAD \& SMITH, supra note 72 , at 80-83 (comparing the recovery from the Great Recession to prior U.S. recessions in the twentieth century).

${ }^{86}$ See Manju Puri, Jörg Rocholl \& Sascha Steffen, Global Retail Lending in the Aftermath of the US Financial Crisis: Distinguishing Between Supply and Demand Effects, 100 J. FIN. ECON. 556, 564-78 (2011); Tara Rice \& Jonathan Rose, When Good Investments Go Bad: The Contraction in Community Bank Lending After the 2008 GSE Takeover, 27 J. FIN. INTERMEDIATION 68, 78-86 (2016); Rebel A. Cole \& Jason Damm, How Did the Financial Crisis Affect Small Business Lending in the U.S.? 30-50 (July 22, 2020) (unpublished manuscript), https://ssrn.com/abstract=1899067 [https://perma.cc/Z6N4-BZAH].

${ }^{87}$ In particular, risks that are hard for the insurer to observe cannot be fairly priced into an insurance contract ex ante. See Bengt Holmstrom, Moral Hazard and Observability, 10 BELL J. ECON. 74, 74-75 (1979). See generally Ralph A. Winter, Optimal Insurance Under Moral Hazard, in HANDBOOK OF INSURANCE 155, 155-57 (Georges Dionne ed., 2000) (providing background on moral hazard in insurance contracts and its relevance in other contexts).

${ }^{88}$ See generally Yuk-Shee Chan, Stuart I. Greenbaum \& Anjan V. Thakor, Is Fairly Priced Deposit Insurance Possible?, 47 J. Fin. 227 (1992) (asserting that it is impossible to fairly price deposit insurance because of moral hazard); John Crawford, The Moral Hazard Paradox of Financial Safety Nets, 25 CORNELL J.L. \& PUB. POL'Y 95, 103-21 (2015) (analyzing moral hazard across both deposit insurance and implicit insurance from bailouts such as the TARP). 
the scope of government deposit insurance and destabilizing risk-taking by insured banks. ${ }^{89}$

Moral hazard is relevant to the too-many-to-fail problem because of the FDIC's TAGP program, which guaranteed small-bank deposits in the United States for more than two years. ${ }^{90}$ At its peak, guarantees from the TAGP covered over 6,800 participating banks and close to $\$ 1$ trillion assets. ${ }^{91}$ Although Dodd-Frank later capped FDIC deposit insurance at $\$ 250,000$ per customer, ${ }^{92}$ TAGP signaled to small banks that, in the event of another serious downturn, policymakers could attempt to circumvent these limits to calm financial markets. ${ }^{93}$ Thus, while de jure deposit insurance is capped at $\$ 250,000$, the de facto level of government deposit guarantees is now potentially unlimited. ${ }^{94}$ All else equal, the higher the insurance coverage, the greater the moral hazard. ${ }^{95}$

Among the most familiar tropes that emerged from the financial crisis was the imperative of saving Main Street consumers and businesses from Wall Street banks. ${ }^{96}$ After taking account of the overlooked too-many-to-fail crisis, that slogan is in need of revision: as it happened, Main Street was hurt by Main Street banks as well. Moreover, because of the moral hazard introduced by emergency measures to stabilize community banks during the crisis, these institutions are now encouraged to adopt risky business models

${ }^{89}$ See, e.g., Charles W. Calomiris \& Matthew Jaremski, Deposit Insurance: Theories and Facts, 8 AnN. Rev. Fin. ECon. 97, 109-12 (2016); Asli Demirgüç-Kunt \& Edward J. Kane, Deposit Insurance Around the Globe: Where Does It Work?, 16 J. ECON. PERSPS. 175, 184-90 (2002).

${ }^{90}$ See FDIC REPORT, supra note 54, at 51-52.

${ }^{91}$ See id. at $52-53$.

${ }_{92}$ Dodd-Frank increased the FDIC deposit insurance limit from $\$ 100,000$ to $\$ 250,000$ per ownership account category, per depositor, per institution. Dodd-Frank Act, Pub. L. No. 111-203, § 335, 124 Stat. 1376, 1540 (codified as amended at 12 U.S.C. $§ 1821(a)(1)(E)$ ).

${ }^{93}$ Cf. Viral V. Acharya \& Tanju Yorulmazer, Too Many to Fail-An Analysis of Time-Inconsistency in Bank Closure Policies, 16 J. Fin. InTERmediation 1, 1 (2007) ("[W]hen the number of bank failures is large, the regulator finds it ex-post optimal to bail out some or all failed banks, whereas when the number of bank failures is small, failed banks can be acquired by the surviving banks.").

${ }^{94}$ The Dodd-Frank Act purported to prohibit the FDIC from increasing the deposit insurance limit in a future crisis. See FDIC REPORT, supra note 54, at 60; see also 12 U.S.C. § 5612(f). Scholars have argued, however, that the FDIC ignored limits on its legal authority when it created the TAGP in 2008. See, e.g., Eric A. Posner, What Legal Authority Does the Fed Need During a Financial Crisis?, 101 MinN. L. REV. 1529, 1560-63 (2017) (describing the FDIC's stated legal basis for the TAGP as "a stretch"). Accordingly, Dodd-Frank's new restrictions on the FDIC's authority might not prevent the FDIC from issuing blanket deposit guarantees in practice.

${ }^{95}$ See Winter, supra note 87, at 155.

96 See, e.g., Sheila Bair, Bull by the Horns: Fighting to Save Main Street from Wall StreEt AND WAll StreEt FROM ItSElF 7, 323-54 (2012) (arguing that large financial institutions should bear the risk of "imprudent behavior" to incentivize protecting the interests of consumers and taxpayers). 
that will be prone to collapse when the next business-cycle trough hits. The upshot is that when it comes to financial regulation, saving Americans from Wall Street is not enough. Financial regulators must account for the direct, indirect, and long-term costs of instability in the community bank sector as well.

The preceding discussion has sought to correct a number of common misconceptions about the role that small banks play in connection with the problem of systemic risk. Its main conclusions can be summarized as follows.

First, every banking crisis in American history has involved a toomany-to-fail component, including 2008. Second, prior to 2008, the too-bigto-fail problem had not characterized a single U.S. banking crisis, despite the growth of large banks over the preceding four decades. ${ }^{97}$ Third, even if every too-big-to-fail bank had remained perfectly stable in 2008 , the too-many-tofail crisis would have nonetheless occurred, and likely with comparable severity. The most plausible counterfactual is that the too-many-to-fail crisis from 2008 to 2013 would rank as either the second- or third-worst banking crisis in modern American history, alongside the 1980s S\&L collapse. Fourth, the economic dynamics underlying the latest too-many-to-fail crisis were not unique. Instead, they are consistent with textbook principles of financial theory on banking-sector vulnerability and unfolded in a manner that closely paralleled prior historical episodes. Finally, the costs of the toomany-to-fail crisis were not contained to the banking sector. Rather, there were strong negative spillovers to the real economy, which created a substantial drag on the recovery from the Great Recession.

The straightforward takeaway from these conclusions is that a welldesigned financial regulatory system must treat community banks as a significant source of systemic risk. As will be explained below, that lesson was largely lost in the postcrisis policy debate and is not reflected in the changes introduced by Dodd-Frank or subsequent regulatory reforms.

${ }^{97}$ Of course, regulatory intervention may have prevented some too-big-to-fail banks from triggering broader distress. See, e.g., FIN. CRISIS INQUIRY COMM'N, PRELIMINARY STAFF REPORT: GOVERNMENTAL RESCUES OF "ToO-BIG-TO-FAIL" FinANCIAL InSTITUTIONS 4-8 (2010) (discussing the resolution of Franklin National Bank in 1974, emergency assistance to First Pennsylvania in 1980, and rescue of Continental Illinois in 1984). 


\section{The MYth of EXCESSIVE COMMUNITY BANK REgUlation}

Despite the too-many-to-fail problem, policymakers and scholars have devoted little attention to the safety and soundness of community banks. In fact, the opposite is true: to the extent that policymakers have focused on community banks, they have generally sought to reduce community bank regulation. Community bank regulatory relief has become a bipartisan touchstone, with legislators from both major parties proclaiming that post2008 reforms unfairly disadvantaged smaller banks. ${ }^{98}$ Legal scholars have rallied around this sentiment as well. ${ }^{99}$ Even fervent banking sector critics like Professor Arthur Wilmarth insist that community banks are subject to excessive regulation. ${ }^{100}$ In short, the regulatory and scholarly consensus has coalesced around two views: (1) that postcrisis rules were uniquely burdensome for community banks, and (2) that community banks require regulatory relief to compete effectively.

Each of these claims, however, is a myth. This Part explains why claims of excessive community bank regulation are unfounded. Section II.A provides the legal analysis. It argues that post-2008 prudential regulatory reforms did not target community banks. In fact, postcrisis rules helped community banks in many ways. Section II.B then explains why the case for community bank regulatory relief lacks merit from an economic perspective. It shows that Dodd-Frank has had no discernable negative impact on the financial performance of community banks. To the contrary, most of the latest data on the small-banking sector indicate that it has been thriving.

\section{A. Assessing Postcrisis Community Bank Regulation}

Despite claims to the contrary, postcrisis rules did not impose unique regulatory burdens on community banks. Instead, policymakers focused primarily on reining in the largest banks. In many cases, Congress and the federal banking agencies shielded community banks from new regulatory burdens and adopted several provisions affirmatively benefiting smaller

\footnotetext{
${ }^{9}$ See, e.g., Mike Konczal, The Power of Community Banks, Politico (Aug. 25, 2016, 9:47 AM), https://www.politico.com/agenda/story/2016/08/political-power-community-banks-hillary-clinton000192 [https://perma.cc/E3D3-B9A6].

${ }^{99}$ See Marsh, supra note 5, at 216-24 (discussing Dodd-Frank's impact on community banks); Schooner, supra note 14, at 158 (asserting that Dodd-Frank compounded community banks' heavy regulatory burden); see also Butz, supra note 22, 465-67 (discussing the Volcker Rule's "unfair and disproportionate" effects on community banks); Newell, supra note 22, at 15-16 (surveying evidence of community banks' compliance costs post-Dodd-Frank); Wilson, supra note 22, at 480-85 (contending that Dodd-Frank increases the regulatory burden on community banks).

100 See Wilmarth, supra note 22, at 282-88 (asserting that Dodd-Frank imposes heavy compliance burdens on community banks).
} 
firms. This Section therefore refutes the popular narrative that post-2008 reforms were uniquely onerous for community banks.

\section{Dodd-Frank Did Not Target Community Banks}

Dodd-Frank and related regulatory initiatives did not single out community banks for adverse regulatory treatment. In fact, to the extent that these reforms distinguished community banks from larger institutions, they protected small banks from harsher rules. Although some postcrisis prudential rules apply to all banks regardless of their size, the federal financial regulators went out of their way to minimize the impact of a onesize-fits-all approach for smaller firms. Thus, the claim that postcrisis reforms unfairly discriminate against community banks lacks merit.

As an initial matter, Dodd-Frank did not establish a single new statutory burden unique to community banks within its nearly 1,000 pages. ${ }^{101}$ Instead, Dodd-Frank sought to safeguard the biggest, internationally active banks, which were perceived as the primary culprits of the 2008 crisis. ${ }^{102}$ As one of the Act's cosponsors, Senator Christopher Dodd, asserted: "The law is squarely aimed at better regulating the largest and most complex Wall Street firms - the ones that were most responsible for the crisis and still present the most risk." ${ }^{103}$ Even vociferous critics concede that "[s]mall banks were not a principal regulatory target of Dodd-Frank." ${ }^{104}$

In the handful of instances where Dodd-Frank explicitly referenced community banks, it was to exempt them from potentially onerous rules. For example, § 165 of Dodd-Frank — which established heightened prudential standards such as stress tests, liquidity requirements, and resolution plansexempted banks with less than $\$ 50$ billion in assets. ${ }^{105}$ Policymakers likewise

101 Cf. AMs. FOR FIN. REFORM, THE IMPACT OF DODD-Frank ON COMMUNITY BANKS (2010), https://ourfinancialsecurity.org/wp-content/uploads/2010/09/CLAIMS-AND-FACTS-FINAL.pdf [https://perma.cc/DKG6-GY8U] (noting that "[m]any key [Dodd-Frank] provisions apply exclusively or mainly to big banks" and "parts of Dodd Frank help shield community banks ... against unfair competition" (emphasis in original)).

102 See, e.g., Christopher J. Dodd, Five Myths About Dodd-Frank, WASH. Post (Oct. 21, 2011), https://www.washingtonpost.com/opinions/five-myths-about-the-dodd-frank-financial-regulations/2011 /10/19/gIQAtq7j4L_story.html [https://perma.cc/224V-Y3H4].

103 Id.

104 Hester Peirce, Ian Robinson \& Thomas Stratmann, How Are Small Banks Faring Under DoddFrank? 7 (Mercatus Ctr., Working Paper No. 14-05, 2014), https:/www.mercatus.org/system/files/ Peirce_SmallBankSurvey_v1.pdf[https://perma.cc/WB3W-S455].

105 See Dodd-Frank Act, Pub. L. No. 111-203, § 165(a)(1), 124 Stat. 1376, 1423 (codified as amended at 12 U.S.C. $\S 5365(\mathrm{a})(1))$. Dodd-Frank required a large bank holding company to participate in annual stress tests conducted by the Federal Reserve and by the company itself to assess whether the firm could withstand a hypothetical economic downturn while maintaining at least the minimum required level of capital. See Matthew C. Turk, Stress Testing the Banking Agencies, 105 IowA L. REV. 1701, 1713-15 
shielded community banks from other novel requirements in the statute, including rules for derivatives clearing, ${ }^{106}$ executive compensation limits, ${ }^{107}$ and risk-management standards. ${ }^{108}$ Moreover, Dodd-Frank exempted community banks from supervision by the newly created Consumer Financial Protection Bureau (CFPB). ${ }^{109}$ Congress and the financial regulatory agencies thereby insulated community banks from many of the most significant postcrisis reforms.

To be sure, some one-size-fits-all postcrisis rules applied to community banks. For instance, Dodd-Frank required all banks to demonstrate compliance with the Volcker Rule's prohibitions on proprietary trading and investments in covered funds, regardless of their size. ${ }^{110}$ In addition, the international Basel III capital accord raised certain capital requirements applicable to all domestic banks. ${ }^{111}$ Dodd-Frank also instructed all depository institutions to ascertain whether mortgage borrowers could reasonably be

(2020). The statute exempted banks with less than $\$ 50$ billion in assets from Federal Reserve-run stress tests and banks with less than $\$ 10$ billion in assets from both Federal Reserve-run and company-run stress tests. See Dodd-Frank Act § 165(i). Dodd-Frank's most prominent liquidity rule requires that a bank holding company maintain sufficient high-quality liquid assets to withstand thirty days of net cash outflows during economic stress. See Turk, supra, at 1752 n.239. Dodd-Frank's resolution-planning requirement directs a large bank holding company to develop a "living will" outlining how the firm could be resolved in an orderly fashion if it were to become insolvent. See Nizan Geslevich Packin, The Case Against the Dodd-Frank Act's Living Wills: Contingency Planning Following the Financial Crisis, 9 BERKELEY Bus. L.J. 29, 39-58 (2012).

106 See, e.g., 17 C.F.R. $§ 50.50$ (d) (2019) (exempting banks with $\$ 10$ billion or less in assets from derivatives-clearing requirements); Dodd-Frank Act $\S 723$ (codified as amended at 7 U.S.C. $\S 2$ ). DoddFrank's derivatives clearing provisions direct the Commodity Futures Trading Commission and the Securities and Exchange Commission to identify certain standardized, liquid swaps that must be cleared through a centralized counterparty or clearinghouse. See Jeremy C. Kress, Credit Default Swaps, Clearinghouses, and Systemic Risk: Why Centralized Counterparties Must Have Access to Central Bank Liquidity, 48 HARV. J. ON LEGIS. 49, 69-71 \& n.121 (2011).

107 See Dodd-Frank Act $\S 956(f)$ (codified at 12 U.S.C. § 5641(f)) (exempting banks with assets of less than $\$ 1$ billion).

${ }^{108}$ See id. $\S 165(\mathrm{~h})(2)(\mathrm{A})$ (codified as amended at 12 U.S.C. $\S 5365(\mathrm{~h})(2)(\mathrm{A})$ ) (specifying that mandatory regulations only apply to companies with consolidated assets of $\$ 10$ billion or more). DoddFrank's risk-management standards require a large bank holding company to establish a risk committee on its board of directors and employ a qualified chief risk officer. See Jeremy C. Kress, Board to Death: How Busy Directors Could Cause the Next Financial Crisis, 59 B.C. L. Rev. 877, 890, 910 (2018).

109 See Dodd-Frank Act $\S 1025$ (a)(1) (codified at 12 U.S.C. $§ 5515(a)(1))$ (applying the supervision requirement to banks with total assets greater than $\$ 10$ billion).

110 See id. $\S 619$ (codified as amended at 12 U.S.C. $\S 1851$ ); see also 12 C.F.R. $\S 248.20$ (2015) (establishing compliance-program requirements for banking entities supervised by the Federal Reserve).

111 See Regulatory Capital Rules: Implementation of Basel III, 78 Fed. Reg. 62018 (Oct. 11, 2013) (codified in scattered sections of 12 C.F.R.); see also Shea Dittrich, How Basel III Capital Requirements Hurt Community Banks, AM. BANKER (Sept. 26, 2012, 12:00 PM), https://www.americanbanker.com/ opinion/how-basel-iii-capital-requirements-hurt-community-banks [https://perma.cc/FG2P-KZ8U] (discussing the effects of Basel III's capital standards on community banks). 
expected to repay their loans by, among other things, verifying their incomes and credit histories. ${ }^{112}$ Community banks insist that these universally applicable rules disproportionately burden them because, unlike big banks, they cannot spread compliance costs over a large asset base. ${ }^{113}$

Even in the case of these one-size-fits-all rules, however, policymakers made special efforts to minimize regulatory burden on community banks. For example, the financial regulatory agencies set the new Basel III capital requirements at a level where few community banks would be forced to raise additional equity. ${ }^{114}$ The agencies also published community bank guides for Basel III, the Volcker Rule, and the "ability-to-repay" rule to help reduce compliance costs for small banks. ${ }^{115}$ Finally, Dodd-Frank required the CFPB to follow a unique rulemaking process under the Small Business Regulatory Enforcement Fairness Act, which grants community banks special opportunities to comment on proposed CFPB regulations. ${ }^{116}$ Thus, although community banks must comply with some postcrisis reforms, policymakers went out of their way to limit regulatory burden on smaller firms.

112 See Dodd-Frank $\S 1411$ (codified as amended at 15 U.S.C. $\S 1639 \mathrm{c}$ note). The CFPB originally exempted community banks with less than $\$ 2$ billion in assets that make 500 or fewer mortgage loans annually from the ability-to-repay requirement. See 12 C.F.R. $\S \S 1026.35(b)(2)(i i i), 1026.43(e)(5)$ (2014). Under pressure from community banks, the CFPB later increased the mortgage threshold to 2,000 loans and excluded originated loans held in portfolio from the limit. See 12 C.F.R. $\S$ 1026.35(b)(2)(iii), 1026.43(e)(5) (2019); see also Kaufman, supra note 14, at, 492-93 (discussing community bank pressure on CFPB to expand the "small-creditor" exemption).

113 See, e.g., Marsh, supra note 5, at 229; Peirce et al., supra note 104, at 12-14.

114 Out of more than 4,600 community banks with less than $\$ 500$ million in assets, only 146 were projected to have to raise capital in order to comply with the new Basel III framework. The remaining community banks were projected to satisfy the new standards without issuing additional capital. See Regulatory Capital Rules: Implementation of Basel III, 78 Fed. Reg. 55340, 55467 (Sept. 10, 2013); Regulatory Capital Rules: Implementation of Basel III, 78 Fed. Reg. 62018, 62152-55 (Oct. 11, 2013).

115 See BD. OF GOvernors of the Fed. RsRv. Sys., FDIC \& OFF. OF THE COMPTroller of Currency, New Capital Rule: Community Bank Guide (2013), https://www.federalreserve.gov/bankinforeg/basel/files/capital_rule_community_bank

guide_20130709.pdf [https://perma.cc/846M-3VJ3]; BD. OF GOVERNORS OF THE FED. RSRV. SYS.,

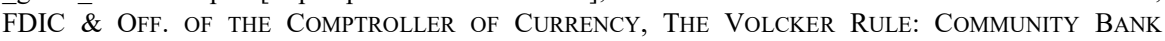
Applicability (2013) [hereinafter Volcker RUle COMPLIANCE Guide], https://www.occ.treas.gov/news-issuances/news-releases/2013/nr-ia-2013-186e.pdf [https://perma.cc/2MWF-LU39]; CFPB, ABILITY-TO-REPAY AND QUALIFIED MORTGAGE RULE: SMALL ENTITY COMPLIANCE GUIDE (2014), https://files. consumerfinance.gov/f/201411_cfpb_atr-qm_small-entity-compliance-guide.pdf [https://perma.cc/ US5Z-CA4J]. The agencies, in particular, went out of their way to minimize the Volcker Rule compliance burden on community banks. See VOLCKER Rule Compliance Guide, supra, at 1 ("The Final Rule is designed to place minimal burden on community banks given the nature of their activities.").

116 See Dodd-Frank Act $\S 1100$ G(a) (codified at 5 U.S.C. $\$$ 609(d)(2)); see also Adam J. Levitin, The Consumer Financial Protection Bureau: An Introduction, 32 ReV. BANKING \& FIN. L. 321, 348-52 (2013) (discussing the Small Business Regulatory Enforcement Fairness Act process). 
In sum, community banks were not a primary target of postcrisis regulatory reforms. Although small banks must comply with some DoddFrank rules, policymakers did not single them out for adverse treatment. To the contrary, Congress and financial regulatory agencies intentionally shielded community banks from the most onerous new rules. Thus, while Dodd-Frank created a complex regulatory framework for the largest U.S. banks, community banks avoided most of these compliance burdens.

\section{Some Postcrisis Reforms Helped Community Banks}

Not only did policymakers protect community banks from potentially burdensome postcrisis rules, but several reforms affirmatively benefitted smaller banks. Dodd-Frank delivered substantial subsidies to community banks, which helped offset their new compliance costs. At the same time, postcrisis reforms reduced too-big-to-fail subsidies for the largest banks, making it easier for community banks to compete. Thus, many overlooked reforms in Dodd-Frank actually advantaged smaller firms.

Policymakers expressly subsidized smaller banks after the financial crisis in three ways. First, Dodd-Frank established a new, community-bankfriendly methodology for assessing contributions to the FDIC's DIF. ${ }^{117}$ This new framework effectively reduced community banks' assessments by shifting the burden of funding the DIF to banks perceived to be too big to fail. ${ }^{118}$ Second, Dodd-Frank exempted banks with less than $\$ 10$ billion in assets from the Durbin Amendment—a statutory cap on the fees banks may charge for debit card transactions. ${ }^{119}$ Finally, when Congress slashed the

117 See, e.g., Dodd-Frank Act $\S 331$ (codified at 12 U.S.C. $\S 1817$ note) (shifting assessment base toward institutions that rely more heavily on nondeposit liabilities); id. $\S 334$ (codified at 12 U.S.C. $\S 1813$ ) (shielding banks with less than $\$ 10$ billion in assets from increased deposit-insurance assessments)

118 See, e.g., Kyle D. Allen, Travis R. Davidson, Scott E. Hein \& Matthew D. Whitledge, DoddFrank's Federal Deposit Insurance Reform, 19 J. BANKING REG. 271, 281 (2018) (concluding that community banks saved approximately $\$ 190$ million per quarter as a result of new assessment methodology).

119 See Dodd-Frank Act $\S 1075$ (a) (codified at 15 U.S.C. $§ 16930-2(a)(6)$ ). As Professor Adam Levitin has noted, this exemption effectively subsidized community banks, which now earn considerably more than larger banks on every debit card transaction. See Rising Regulatory Compliance Costs and Their Impact on the Health of Small Financial Institutions: Hearing Before the Subcomm. on Fin. Insts. \& Consumer Credit of the H. Comm. on Fin. Servs., 112th Cong. 17 (2012) (statement of Adam J. Levitin, Professor of Law, Georgetown University Law Center) [hereinafter Levitin, Rising Regulatory Compliance Costs] ("[T] he Durbin ... Amendment is the single best piece of legislation for community banks in the past [two] decades."); see also Rising Regulatory Compliance Costs and Their Impact on the Health of Small Financial Institutions: Hearing Before the Subcomm. on Fin. Insts. \& Consumer Credit of the H. Comm. on Fin. Servs., 112th Cong. 65 (2012) (written testimony of Adam J. Levitin, Professor of Law, Georgetown University Law Center) ("[S]maller banks . . . are making on average . . 19 cents more than large banks on every debit card transaction."). 
annual dividend that the Federal Reserve pays to member banks from $6 \%$ to the prevailing ten-year Treasury rate in 2015 , policymakers shielded banks with less than $\$ 10$ billion from that reduction. ${ }^{120}$

Collectively, these subsidies offset most, if not all, of community banks' new postcrisis prudential regulatory burden. Based on conservative estimates, community banks earn roughly $\$ 1.25$ billion annually from the three provisions described above. ${ }^{121}$ As Table 1 demonstrates, these subsidies thus completely negate community banks' compliance costs associated with Basel III, the Volcker Rule, and the ability-to-repay rule-the most significant postcrisis prudential reforms applicable to smaller banks. ${ }^{122}$ All told, the new subsidies offset roughly one-quarter of community banks' $\$ 5$ billion in total annual compliance costs. ${ }^{123}$ These new, but often-overlooked subsidies therefore neutralize much of community banks' well-publicized regulatory burden.

Table 1: Comparing Postcrisis Community Bank Compliance Costs And Subsidies

\begin{tabular}{|c|c|c|c|}
\hline $\begin{array}{c}\text { Annual Compliance Costs (\$ } \\
\text { millions) }\end{array}$ & \multicolumn{2}{|c|}{ Annual Subsidies (\$ millions) } \\
\hline Basel III ${ }^{124}$ & $\$ 238$ & Deposit insurance premium reduction $^{125}$ & $\$ 760$ \\
\hline
\end{tabular}

${ }^{120}$ See Fixing America's Surface Transportation Act, Pub. L. No. 114-94, § 32203(a), 129 Stat. 1312, 1739-40 (2015) (codified at 12 U.S.C. § 289(a)(1)(A)(ii)).

${ }^{121}$ See infra Table 1; infra notes 125, 127, 129.

122 These estimates take into account only the direct costs of complying with the relevant regulations - such as paperwork, recordkeeping, and disclosure requirements - and not indirect effects of these regulations, such as foregone revenues or higher costs of capital.

${ }^{123}$ The Federal Reserve and Conference of State Bank Supervisors (CSBS) have estimated that community bank compliance costs ranged from $\$ 4.5$ billion to $\$ 5.4$ billion annually between 2014 and 2018. See Fed. RSRV. Sys., FDIC \& CONF. OF State Bank Supervisors, Community Banking IN the 21 ST CENTURY 2019, at 54 (2019), https://www.communitybanking.org/ /media/files/publication/ cb21publication_2019.pdf [https://perma.cc/NE9J-C6GV].

124 Total compliance costs for banks with less than $\$ 10$ billion in assets were $\$ 5.4$ billion in 2016, according to estimates by the Federal Reserve and CSBS. Of that total, 4.4\% - or $\$ 238$ million-was attributable to compliance with Basel III. See FeD. RsRV. Sys. \& CONF. OF State BanK SuPERVISORS, COMMUNITY BANKING IN THE 21st CENTURY 2017, at 20-21 (2017) [hereinafter 2017 COMMUNITY BANK SURVEY], https://www.communitybanking.org/ /media/files/cb21pub_2017_book_web.pdf [https://perma.cc/TLM8-C7HE].

${ }^{125}$ According to an academic study, Dodd-Frank's deposit-insurance reforms have reduced community banks' assessments by approximately $\$ 190$ million per quarter, or $\$ 760$ million per year. See Allen et al., supra note 118, at 281. This figure underestimates the full benefit of the deposit-insurance reforms, as it omits rebates to which community banks have been entitled since the Deposit Insurance Fund Reserve Ratio reached a threshold of $1.38 \%$ in June 2019. See Deposit Insurance Assessments: Small Bank Credits, FDIC, https://www.fdic.gov/deposit/insurance/assessments/small-bank-credits.html [https://perma.cc/HJC7-UDTH] (last updated Dec. 23, 2019) (explaining FDIC small-bank assessment credits and reporting that the Reserve Ratio reached 1.40\% in June 2019); Deposit Insurance 
N O R T H W E S TER N UNIVERS IT Y L A W RE VIE W

\begin{tabular}{|c|c|c|c|}
\hline Volcker Rule $^{126}$ & $\$ 47$ & Durbin Amendment exemption & 127 \\
\hline $\begin{array}{c}\text { Ability-to-repay } \\
\text { rule }^{128}\end{array}$ & $\$ 793$ & Federal Reserve dividend exemption & $\$ 327$ \\
\hline $\begin{array}{c}\text { Total Compliance } \\
\text { Costs }\end{array}$ & $\$ 1,078$ & Total Subsidies & $\$ 1,215$ \\
\hline
\end{tabular}

Assessments: Assessment Changes Since 2016, FDIC, https://www.fdic.gov/deposit/insurance/ assessments/changesassessments.html\#: :text=When\%20the\%20reserve\%20ratio\%20reaches, $1.35 \% 25$ $\% 20$ (see\%20below) [https://perma.cc/K5ZH-GWDW] (noting the Reserve Ratio threshold for smallbank credits). The value of rebates is expected to approach $\$ 765$ million. See Andy Peters, Small Banks About to Catch Break on Deposit Insurance Premiums, AM. BANKer (Feb. 28, 2019, 1:19 PM), https://www.americanbanker.com/news/small-banks-about-to-catch-break-on-deposit-insurancepremiums [https://perma.cc/2KQ2-WSU4].

126 The Federal Reserve estimated that the paperwork, recordkeeping, and disclosure-related requirements associated with the Volcker Rule resulted in $\$ 9,225$ in annual compliance costs, on average, for a community bank. See Revisions to Prohibitions and Restrictions on Proprietary Trading and Certain Interests in, and Relationships with, Hedge Funds and Private Equity Funds, 84 Fed. Reg. 35008, 35012 n.44 (July 22, 2019). Multiplying across 5,113 insured depository institutions with less than $\$ 10$ billion in assets results in a total community bank Volcker Rule compliance burden of roughly $\$ 47$ million annually. See Quarterly Banking Profile: Third Quarter 2019, 13 FDIC Q., no. 4, 2019, at 7 (providing number of banks with less than $\$ 10$ billion in assets).

${ }^{127}$ Professors Vladimir Mukharlyamov and Natasha Sarin have calculated that the Durbin Amendment reduced interchange income for banks subject to the rule by approximately $25 \%$. See Mukharlyamov \& Sarin, supra note 30, at 19. According to data reported on the Federal Reserve's Form FR Y-9C and accessed on the Wharton Research Data Services database, banks with less than $\$ 10$ billion in assets earned a total of $\$ 1.31$ billion in interchange income in 2010, before the Durbin Amendment became effective. Therefore, assuming that the Durbin Amendment would have affected community and noncommunity banks equally, the community bank exemption from the Durbin Amendment effectively subsidized those banks by roughly $\$ 327$ million per year.

128 This figure includes community banks' costs of complying with both the ability-to-repay rule and the qualified-mortgage rule, a safe harbor provision that permits banks to presumptively satisfy the ability-to-repay requirement by issuing mortgages with certain standardized terms. See Patricia A. McCoy \& Susan M. Wachter, The Macroprudential Implications of the Qualified Mortgage Debate, 83 LAw \& CONTEMP. PROBS. 21, 28-31 (2020) (discussing the ability-to-repay rule and qualified-mortgage safe harbor). The Federal Reserve and CSBS estimated that the ability-to-repay rule and qualified-mortgage rules accounted for $6.7 \%$ and $8.0 \%$, respectively, of community banks' compliance costs in 2016. See 2017 COMMUNITY BANK SURVEY, supra note 124, at 20 . Thus, out of community banks' total $\$ 5.4$ billion compliance burden, approximately $\$ 793$ million was attributable to the ability-to-repay requirement and qualified-mortgage safe harbor. See id. at 21.

129 The Federal Reserve paid a total of $\$ 1.7$ billion in dividends to member banks in 2015, before the dividend rate cut became effective. See BD. OF GOVERnORS OF THE FED. RSRV. SYS., 105TH ANNUAL REPORT 318 (2019), https://www.federalreserve.gov/publications/files/2018-annual-report.pdf [https:// perma.cc/AD8H-6WMP]. When the rate cut went into effect in 2016-and banks with $\$ 10$ billion or more in assets received a dividend equal to the prevailing ten-year Treasury rate instead of $6 \%$ - total dividends paid dropped to $\$ 711$ million. See id. at 318, 362-63. Assuming that the Federal Reserve paid a $2 \%$ dividend to banks subject to the rate cut, we algebraically determine that the community bank exemption from the rate cut was worth approximately $\$ 128$ million to banks with less than $\$ 10$ billion in assets. See, e.g., DeP'T OF the TREASUry, Treasury Auction Results (2016), https://www.treasurydirect.gov/instit/annceresult/press/preanre/2016/R_20161109_1.pdf [https:// perma.cc/8YRE-9LVA] (noting the high yield of the ten-year Treasury note was $2.02 \%$ ). 
In addition to creating new subsidies for community banks, postcrisis reforms also reduced subsidies for large banks - thereby making it easier for small banks to compete on a level playing field. For many years, banks considered "too big to fail" borrowed at artificially low rates because creditors believed that the government would bail out such firms rather than allow them to collapse. ${ }^{130}$ Community banks have often contended that this implicit subsidy gave large banks an unfair advantage over smaller banks, which lacked the government's implicit backing and therefore had a higher cost of capital. ${ }^{131}$ By imposing new prudential rules on the largest banks and creating a more credible big-bank resolution regime, however, Dodd-Frank substantially reduced the too-big-to-fail subsidy. ${ }^{132}$ According to one study, for example, the Dodd-Frank reforms shrank the implicit subsidy for the largest banks by $94 \%{ }^{133}$ By reducing big-bank subsidies, policymakers helped community banks compete with larger banks on more equal terms.

Other postcrisis reforms have aided community banks through more subtle channels. In 2015, for example, Congress mandated that at least one seat on the Federal Reserve's seven-member governing board be reserved for a person with experience working in or supervising community banks. ${ }^{134}$ The primary effect of this special designation is to give community banks

130 See, e.g., Saule T. Omarova, The "Too Big to Fail” Problem, 103 Minn. L. REV. 2495, 2500 (2019) (discussing the "too-big-to-fail" subsidy).

131 See IndeP. CMTy. BANKers of AM., End Too-Big-TO-FAil 3, 10-11 (2013), https://www. icba.org/docs/default-source/icba/news-documents/press-release/2013/endtbtfstudy.pdf $\quad$ [https:// perma.cc/9LGW-YUWL].

${ }^{132}$ The reduced magnitude of the too-big-to-fail subsidy may also reflect creditors' belief, in light of the TAGP, that community banks also enjoy an implicit government backstop. Econometric studies, however, typically attribute the decline in too-big-to-fail banks' funding advantage to the effect of DoddFrank. See, e.g., Int'L Monetary Fund, Global Financial Stability Report: Moving from LIQUIDITY- TO GROWTH-DRIVEN MARKETS 104-25 (2014), https://www.imf.org/en/Publications/ GFSR/Issues/2016/12/31/Moving-from-Liquidity-to-Growth-Driven-Markets [https://perma.cc/J6EV$63 \mathrm{HD}]$ (concluding that postcrisis regulatory reforms limited the too-big-to-fail subsidy in the United States).

${ }^{133}$ See Bhanu Balasubramnian \& Ken B. Cyree, Has Market Discipline on Banks Improved After the Dodd-Frank Act?, 41 J. BANKING \& FIN. 155, 165 (2014); see also INT'L MONETARY FUND, supra note 132, at 104-19; U.S. GOV'T ACCOUNTABILITY OFF., GAO-14-621, LARGE BANK HOLDING COMPANIES: EXPECTATIONS OF GOVERNMENT SUPPORT 46-55 (2014), https://www.gao.gov/assets/670/665162.pdf [https://perma.cc/7M77-6V6N] (finding that expectations of government support for large banks diminished after the Dodd-Frank Act). But see Viral V. Acharya, Deniz Anginer \& Joe Warburton, The End of Market Discipline? Investor Expectations of Implicit Government Guarantees 30-33 (Munich Personal RePEc Archive, Working Paper No. 79700, 2016) (finding that Dodd-Frank did not significantly reduce expectations of government support for large financial institutions).

134 Terrorism Risk Insurance Program Reauthorization Act of 2015, Pub. L. No. 114-1, § 109(a), 129 Stat. 3, 9 (codified at 12 U.S.C. § 241). 
greater influence over future regulatory matters. ${ }^{135}$ Additionally, as mentioned above, Dodd-Frank raised the deposit-insurance limit from $\$ 100,000$ to $\$ 250,000$ per account, which will help community banks compete against larger banks for consumer deposits. ${ }^{136}$ Lastly, Dodd-Frank eliminated disclosure requirements that had previously forced small, publicly traded banks to report annually on the effectiveness of their internal controls over financial reporting. ${ }^{137}$ With these various reforms, policymakers both empowered community banks and mitigated their compliance burden.

In sum, community banks benefitted from Dodd-Frank and other postcrisis reforms in several underappreciated ways. Policymakers not only subsidized community banks directly, they also rolled back implicit subsidies for larger firms. In total, this redistribution likely offset the financial drag from new prudential regulations imposed on community banks after the crisis. Any assessment of postcrisis community bank regulation is thus fatally incomplete unless it accounts for the substantial benefits such firms received in the aftermath of 2008.

\section{B. The Empty Case for Community Bank Regulatory Relief}

Even though Dodd-Frank did not disproportionately burden smaller firms, the community bank lobby and even impartial observers insist that small banks need regulatory relief in order to remain viable. This conclusion is usually supported by two claims: (1) the community bank sector has experienced economic decline in the decade following the financial crisis, and (2) community banks require deregulation or explicit subsidies to compete with larger firms. Both of these premises, however, are false. As this Section demonstrates, community banks have generally thrived since the 2008 financial crisis. And, for related reasons, additional small-bank deregulation or subsidization is unwarranted.

${ }_{135}$ See Pedro Nicolaci da Costa, Senate Approves Move to Reserve Fed Seat for Community Banks, WALL ST. J. (July 17, 2014, 1:21 PM), https://blogs.wsj.com/economics/2014/07/17/senate-approvesmove-to-reserve-fed-seat-for-community-banks/ [https://perma.cc/TAZ8-3AYW]

136 See Dodd-Frank Act, Pub. L. No. 111-203, § 335(a), 124 Stat. 1376, 1540 (codified at 12 U.S.C. $\S 1821(\mathrm{a})(1)(\mathrm{E}))$; see also U.S. Gov'T ACCOUNTABILITY OFF., GAO-12-881, COMMUNITY BANKS AND CREDIT UNIONS: IMPACT OF THE DODD-FranK ACt DEPENDS LARGELY ON FUTURE RULE MAKINGS 24 (2012), https://www.gao.gov/assets/650/648210.pdf [https://perma.cc/6RKA-F72W] (“According to FDIC, the higher insurance coverage level should help community banks attract and retain core deposits.").

137 See Dodd-Frank Act $\S 989$ G (codified at 15 U.S.C. $\S 7262$ ). The Government Accountability Office estimated that auditing fees associated with these reporting requirements cost small, publicly traded companies roughly $\$ 250,000$ per year, on average. See U.S. GOV'T ACCOUNTABILITY OFF., supra note 136 , at $26-27$. 


\section{Community Banks Have Thrived Since the Financial Crisis}

The case for community bank regulatory relief typically proceeds from the observation that the sector has been "shrinking" in the years since DoddFrank was enacted in $2010 .{ }^{138}$ In one very narrow sense, this observation is correct. According to FDIC statistics, there were roughly 6,500 community banks with less than $\$ 10$ billion in assets in the United States in $2010 .{ }^{139}$ By 2020, there were 4,337. ${ }^{140}$ When placed in broader context, however, this headline figure does little to illuminate the relationship between postcrisis reforms and small banks. Taking into account historical trends, macroeconomic forces, and cross-sectional performance, the community bank sector has on the whole experienced healthy growth, despite the overall decline in the number of small banks.

The decreasing number of community banks is not a new trend. To the contrary, there has been a roughly continuous decline in the population of community banks since the mid-1990s. ${ }^{141}$ Any reduction in the amount of community banks since 2010 therefore reflects the persistence of a trend that began long before Dodd-Frank. ${ }^{142}$ To the extent the quantity of community banks is a relevant metric for gauging the economic health of the smallbanking sector, post-2008 reforms have no correlation with the rate of change in that variable over time.

Moreover, as Federal Reserve Chairman Jerome Powell has recently noted, taking a disaggregated view of the community bank sector is critical because the performance of small financial institutions has been far from uniform. ${ }^{143}$ Indeed, the headline trend of community bank decline, upon which advocates of regulatory relief rely, is driven almost entirely by a collapse in the number of banks with less than $\$ 100$ million in assets. ${ }^{144}$ Between 1995 and 2010, community banks in the $\$ 1$ billion to $\$ 10$ billion size bracket roughly doubled in number, growing at a faster rate than banks

138 See, e.g., Peirce et al., supra note 104, at 10-11.

139 Quarterly Banking Profile: Fourth Quarter 2010, 5 FDIC Q., no. 1, 2011, at 7.

140 Quarterly Banking Profile: First Quarter 2020, 14 FDIC Q., no. 2, 2020, at 7.

141 See Jerome H. Powell, Member, Bd. of Governors of the Fed. Rsrv. Sys., Trends in Community Bank Performance over the Past 20 Years: Remarks at Fourth Annual Community Banking Research and Policy Conference 2, fig.1 (Sept. 29, 2016), https://www.federalreserve.gov/newsevents/speech/files/ powell20160929a.pdf [https://perma.cc/P4PS-WLU6].

142 See id. at 2-4.

143 See id.

144 See id. at 3; see also Martin NeIl Baily \& Nicholas Montalbano, Brookings Econ. Studs., The Community Banks: The Evolution of the Financial Sector, Part III, at 1 (2015), https://www.brookings.edu/wp-content/uploads/2016/07/Baily_Montalbano_CommunityBanks_122115 .pdf [https://perma.cc/7TH3-LPG6] (showing variation in the growth of relatively large and small community banks). 
above that threshold. ${ }^{145}$ The quantity of community banks with between $\$ 300$ million and $\$ 1$ billion in assets followed a similar trajectory as well. ${ }^{146}$ Thus, in contrast to the popular narrative, the number of community banks above the very smallest size threshold has been rising at a rapid clip, not shrinking.

Importantly, the shrinking population of micro-community banks with less than $\$ 100$ million in assets is almost entirely unrelated to Dodd-Frank. The most important drivers of this decline are legal reforms from the 1980s and 1990s, such as the Riegle-Neal Interstate Banking and Branching Efficiency Act of 1994, ${ }^{147}$ which allowed banks to operate multiple branches and merge across state lines for the first time. ${ }^{148}$ As a result, the smallest banks were absorbed into larger conglomerates through acquisition and typically converted into branches of the acquiring bank thereafter. ${ }^{149}$ The drop in standalone community banks during the initial decades of banking industry consolidation is therefore easily explained - prior to the mid-1980s, it was illegal for community banks to expand through mergers. ${ }^{150}$

In addition to these precrisis reforms, the smallest community banks have declined in number since the financial crisis for two separate reasons. The first is organic growth. For some years, up to $90 \%$ of the micro-sized community banks that have "disappeared" since Dodd-Frank simply moved up to the next size bracket. ${ }^{151}$ Rather than being acquired or shackled by new regulations, these banks merely crossed definitional categories by expanding their lending activities and gaining market share.

The second reason is a lack of entry by newly chartered institutions, known as "de novo banks." 152 Most new banks are small and, somewhat remarkably, not a single de novo bank was chartered in the United States from 2010 to $2015 .{ }^{153}$ From 1995 to 2007, the average rate of de novo bank

\footnotetext{
145 Powell, supra note 141, at 2-3.

${ }^{146} I d$. at 3. The number of banks with between $\$ 100$ million and $\$ 300$ million in assets declined by "a very modest percentage." Id.

147 See Riegle-Neal Interstate Banking and Branching Efficiency Act of 1994, Pub. L. 103-328, $\S \S 101-02,108$ Stat. 2338, 2339-52 (codified as amended in scattered sections of 12 U.S.C.).

148 See generally Philip E. Strahan, The Real Effects of U.S. Banking Deregulation, 85 FED. RSRV. BANK ST. LouIS REV. 111, 111, 114 (2003) (analyzing the role of regulatory reforms from the 1970s to 1990s on the increasing concentration of the banking sector which followed).

149 CALOMIRIS \& HABER, supra note 34, at 193-202 (discussing early bank mergers).

150 See id.

151 See Powell, supra note 141, at 3.

152 See Roisin McCord \& Edward Simpson Prescott, The Financial Crisis, the Collapse of Bank Entry, and Changes in the Size Distribution of Banks, 100 FED RSRV. BANK Rich. ECON. Q. 23, 23-24 (2014).

${ }^{153}$ See Powell, supra note 141, at 3-4, fig.6.
} 
charters hovered around 130 institutions per year. ${ }^{154}$ As Federal Reserve Chairman Powell points out, once controlling for the recent lack of entryin a counterfactual world where the precrisis pace of de novo charters held steady - there would have been no increased rate of decline in the number of community banks since $2010 .{ }^{155}$

Critically, this drop in small de novo banks cannot be attributed to regulatory burden imposed by postcrisis reforms. According to one leading academic study, $75 \%$ of the reduction in new entry is explained by adverse macroeconomic conditions during the Great Recession, independent of regulatory changes. ${ }^{156}$ Specifically, the low-interest-rate environment and limited demand for credit after 2008 meant that opening a de novo bank was an unattractive business proposition. ${ }^{157}$

More fundamentally, the total number of community banks is less relevant to the overall performance of the small-banking sector than is their lending and profitability. Here again, the data do not reflect any effect from Dodd-Frank. While earnings of community banks above the $\$ 100$ million threshold lagged slightly behind those of the too-big-to-fail institutions between 1995 and 2010, that gap did not widen in subsequent years. ${ }^{158}$ Moreover, total lending by community banks across nearly all size categories has grown steadily since 2010 and returned to precrisis levels. ${ }^{159}$ The relevant data therefore do not suggest that community banks have suffered as a result of Dodd-Frank.

Notably, mid-sized community banks with between $\$ 300$ million and $\$ 1$ billion in assets "have been the most consistently profitable group among community banks ... [and have] performed as well as banks with $\$ 1$ billion to $\$ 10$ billion in assets." 160 If the regulatory relief hypothesis is that DoddFrank's legal burden increases significantly with the inverse of bank size, one would expect that the largest community banks would have

${ }^{154}$ See Number of New Banks Created by Year, 1993 to 2018, InST. FOR LOCAL SELF-RELIANCE (May 14, 2019), https://ilsr.org/number-of-new-banks-created-by-year-1993-to-2013/ [https://perma.cc/ 73WB-GC92].

155 See Powell, supra note 141, at 4, fig.6.

156 Robert M. Adams \& Jacob Gramlich, Where Are All the New Banks? The Role of Regulatory Burden in New Bank Formation, 48 REV. INDUS. ORG. 181, 204 (2016).

${ }^{157}$ See id. A 2016 study undertaken by the Obama Administration's Council of Economic Advisors arrived at the same conclusion. See Council of ECon. Advisers, The Performance of Community BANKS OVER TIME 2 (2016).

158 See Powell, supra note 141, at 5; Baily \& Montalbano, supra note 144, at 8.

159 See, e.g., COUNCIL OF ECON. Advisors, supra note 157, at 2 ("The annual growth rate of lending by community banks in each asset range ... has increased since the financial crisis and reached levels ... in line with rates seen prior to the crisis ....").

160 See Powell, supra note 141, at 5, fig.7. 
outperformed mid-sized community banks after 2010. But that does not appear to be the case: there has been no compression of profits or lending within the community bank sector relative to size over time, nor for community banks relative to too-big-to-fail banks. ${ }^{161}$

The regulatory-relief hypothesis fares even worse in light of the latest FDIC data for 2018 and 2019. Small banks have experienced double-digit earnings growth the past two years, with the rise in community bank profits exceeding earnings at too-big-to-fail institutions in several financial quarters. ${ }^{162}$ Indeed, at year-end 2019, FDIC Chairman Jelena McWilliams boasted that community banks "reported another positive quarter," with "the annual loan growth rate at community banks outpac[ing] the overall industry's growth rate."163

Viewed as a whole, community banks' financial performance reveals that the regulatory-burden narrative surrounding postcrisis reforms relies more on myth than fact. After disaggregating among community banks and accounting for economic factors unrelated to the regulatory environment, the number and profitability of community banks shows no relationship to the passage of Dodd-Frank. And putting micro-sized community banks aside, the small banking sector is thriving. This outcome should not be mysterious in light of the analysis presented by the foregoing Part. As that discussion explained, postcrisis reforms largely ignored small banks, while explicitly targeting a wide variety of novel restrictions at too-big-to-fail institutions. ${ }^{164}$ The unsurprising result is that the community-bank sector has flourished over the past several years, notwithstanding claims to the contrary.

\section{Community Banks Do Not Require Special Subsidies}

In a financial system dominated by too-big-to-fail megabanks, it is tempting to conceptualize the community bank sector as a beleaguered

\footnotetext{
161 See id.; see also Jared Fronk, Core Profitability of Community Banks: 1985-2015, 10 FDIC Q., no. 4, 2016, at 37 (providing statistics on the profitability of community banks in the decades before and after the financial crisis, following the same performance trends as the banking industry overall).

162 See, e.g., Quarterly Banking Profile: Third Quarter 2019, 13 FDIC Q., no. 4, 2019, at 1, 15 (reporting that community banks' net income increased by $7.2 \%$ year-over-year, compared to a decline in net income for large banks); Quarterly Banking Profile: Second Quarter 2019, 13 FDIC Q., no. 3, 2019 , at 1, 15 (reporting that community bank net income increased by $8.1 \%$ year-over-year, compared to only $4.1 \%$ for the banking sector as a whole); see also Martin Neil Baily \& Nicholas Montalbano, PostCrisis, Community Banks Are Doing Better than the Big Four by Some Measures, BrooKings (Dec. 21, 2015), https://www.brookings.edu/research/post-crisis-community-banks-are-doing-better-than-the-bigfour-by-some-measures/ [https://perma.cc/V4Y6-93DQ].

163 Jelena McWilliams, Chairman, FDIC, Remarks on the Fourth Quarter and Full-Year 2019 Quarterly Banking Profile (Feb. 25, 2020), https://www.fdic.gov/news/news/speeches/spfeb2520.html [https://perma.cc/8QDF-RHQJ].

164 See supra Section II.A.
} 
underdog. But that would be a mistake. The conventional wisdom that community banks require deregulation has in large part gained acceptance due to decades of financial sector lobbying. ${ }^{165}$ The small-bank lobby-now led by the Independent Community Bankers of America (ICBA) - is among the most successful political interest groups in U.S. history and has wielded outsized influence over financial regulation since the early nineteenth century. ${ }^{166}$ The regulatory relief narrative that has taken hold since 2010 is only its latest achievement.

This industry-led campaign has been buttressed by support from academic commentators as well. ${ }^{167}$ Indeed, the modest body of legal scholarship that has examined community banking in recent years reflects a nearly uniform view that small banks have been overly burdened by DoddFrank and related postcrisis reforms. ${ }^{168}$ Much of this academic literature goes even further. Academics often assert that community banks not only need regulatory relief in order to survive but also require implicit or explicit subsidies in order to remain viable in the modern financial system. ${ }^{169}$

Banking law experts, including Professors Marsh and Wilmarth, generally present three arguments why affirmative community-bank subsidies are necessary. First, they argue that the alleged decline of

\footnotetext{
165 See, e.g., Konczal, supra note 98.

${ }^{166}$ Support for community banks is historically rooted in the Jeffersonian and Jacksonian populist tradition, with agrarian interests strongly favoring small, locally run banks to larger banks in urban money centers. See Mehrsa Baradaran, How the Other Half Banks: Exclusion, Exploitation, and THE THREAT TO DEMOCRACY 28-32 (2015). This historical coalition of rural famers and small bankers has shaped U.S. financial regulatory policy ever since. See CALOMIRIS \& HABER, supra note 34, at 15455 (tracing the role of populists and community bankers in the evolution of the U.S. banking sector). Urban interests have likewise supported the community bank sector as an alternative to too-big-to-fail banks for meeting the needs of underserved communities. See, e.g., MEHRSA BARADARAN, THE COLOR OF MONEY: BLACK BANKS AND THE RACIAL WEALTH GAP 230-35 (2017) (discussing efforts to promote small banks in low- and moderate-income communities). For information on the role of the ICBA, see About ICBA, INDEP. CMTY. BANKERS OF AM., https://www.icba.org/about [https://perma.cc/7UYH$\mathrm{X} 8 \mathrm{~B} 6]$.

${ }^{167}$ See, e.g., Wilmarth, supra note 22, at 253-54 (arguing that postcrisis reforms "benefited megabanks while suppressing the earnings of community banks"). But see Schooner, supra note 14, at 146 (taking a skeptical view of deregulating community banks).

168 See, e.g., Wilmarth, supra note 22, at 277 ("The future viability of community banks has also been called into question because of ... the costly new compliance requirements that Dodd-Frank and the Basel III capital accord have imposed on community banks."); see also Newell, supra note 22, at 14 ("Dodd-Frank compels both large banks and community banks to meet new regulatory requirements even though community banks played no substantial role in the financial crisis.").

${ }^{169}$ For example, Professor Wilmarth has advocated for: (a) more federal aid for community banks during the crisis; (b) federally subsidized small-business loan guarantees for community banks; (c) relaxed supervisory scrutiny for community banks; and (d) regulatory forbearance for community banks that fail to satisfy supervisory standards. Wilmarth, supra note 22 , at $257,268,277-81,340-42$.
} 
community banks must be prevented because small banks provide an important counterweight to the concentration of financial assets in too-bigto-fail institutions. ${ }^{170}$ Second, they contend that any reduction in the number of community banks should be avoided because further consolidation of the banking sector will have a negative effect on access to credit for small businesses and local communities. ${ }^{171}$ And third, they argue that absent subsidies, community banks - and the specialized relational-lending services that they provide - will be displaced because small banks cannot withstand "competitive pressures" from larger banks when all financial firms operate on an even playing field. ${ }^{172}$ Upon closer inspection, however, none of these three justifications for community bank subsidies is persuasive.

First, the view that policymakers should support community banks to prevent concentration of the financial sector in too-big-to-fail institutions is a red herring. As many community banks are quite small, any attempt to bolster their number would yield trivial results, even in the most optimistic case. ${ }^{173}$ For example, assuming the number of banks with less than $\$ 100$ million in assets doubled overnight, the aggregate increase in assets in the community bank sector would equal roughly $\$ 120$ billion. ${ }^{174}$ Further assuming that all assets held by those new small banks were diverted from a single too-big-to-fail bank such as JPMorgan, the decline in JPMorgan's assets would be negligible, falling from $\$ 2.6$ trillion to $\$ 2.5$ trillion. ${ }^{175}$ As it stands, nearly half of all banking-system assets are held by the five largest institutions. ${ }^{176}$ If the too-big-to-fail issue or excessive financial sector concentration are policy problems, the appropriate remedy is to break up the

170 See Marsh, supra note 5, at 185-86; Wilmarth, supra note 22, at 250.

171 See Wilmarth, supra note 22, at 299 ("Any further decline in the competitive presence of community banks would harm consumers and local communities as well as entrepreneurs."); Stephen Michael Spivey, Note, A Snake Eating Its Own Tail: The Self-Defeating Nature of an Overly Broad Implementation of Section 1071, 22 N.C. BANKING INST. 107, 117-19 (2018).

172 See Marsh, supra note 5, at 224-25; Newell, supra note 22, at 3 (advocating that the "FDIC should continue its recent trend of loosening community-banking regulations in order to maintain the competitive balance of the banking industry"); Spivey, supra note 171, at 122 ("[C]ompetitive pressures and burdensome compliance costs ... [are] shrinking the [small-banking] market and leading some in the industry to predict that community banks will eventually disappear entirely.").

173 As of September 2019, there were 1,206 community banks with less than $\$ 100$ million in assets. Quarterly Banking Profile: Third Quarter 2019, supra note 62, at 1, 7.

174 See id.

175 See JPMorgan Chase \& Co., 2019 Annual Report (Form 10-K), at 40 (Feb. 25, 2020).

176 See Jeff Cox, 5 Biggest Banks Now Own Almost Half the Industry, CNBC (Apr. 15, 2015, 2:33 PM), https://www.cnbc.com/2015/04/15/5-biggest-banks-now-own-almost-half-the-industry.html [https://perma.cc/4WQW-SNEE] (explaining that JPMorgan Chase, Bank of America, Wells Fargo, Citigroup, and U.S. Bancorp together control $44.61 \%$ of the industry's total assets). 
biggest banks. ${ }^{177}$ Artificially supporting community banks will not meaningfully address these issues.

Second, subsidizing community banks to preserve access to credit in "underbanked" areas would be equally misguided. Legal scholarship has suggested that certain geographies have lost physical access to financial services as a result of community bank consolidation. ${ }^{178}$ But this concern is overstated. When small banks are acquired, they do not disappear. ${ }^{179}$ Rather, the acquirer typically converts the target bank into a branch and therefore maintains operations in the target's original community. ${ }^{180}$ To be sure, there is some evidence that the acquisition of a community bank by a larger, outof-market institution reduces the supply of credit to the target's community. ${ }^{181}$ But in the case of the smallest community banks, this effect is at least partially offset by the stability benefits of the target consolidating with a larger, more stable firm. ${ }^{182}$ Community bank subsidies, therefore, do not necessarily enhance underserved areas' long-term access to credit. ${ }^{183}$

177 See Levitin, Rising Regulatory Compliance Costs, supra note 119, at 63; Jeremy C. Kress, Solving Banking's 'Too Big to Manage' Problem, 104 MINN. L. REV. 171, 213-15 (2019) (advocating for forced divestitures by too-big-to-manage banks).

178 See Wilmarth, supra note 22, at 298-300; Newell, supra note 22, at 9-12. Data on community bank consolidation are mixed. On one hand, FDIC statistics indicate that the number of rural American counties with physical access to a local bank office that practices relational lending has not declined. See COUNCIL OF ECON. ADVISERS, supra note 157, at 2. On the other hand, the number of banks headquartered in rural communities appears to be declining due to consolidation. See BD. OF GOVERNORS OF THE FED. RsRv. Sys., Perspectives from Main Street: Bank Branch Access in RuRal Communities 3 (2019), https://www.federalreserve.gov/publications/files/bank-branch-access-in-rural-communities.pdf [https://perma.cc/R7UK-GZKC] (noting that more than 100 rural banking markets went from containing at least one bank's headquarters to no bank headquarters between 2012 and 2017).

${ }^{179}$ Consolidation over the past decade has primarily consisted of the acquisition of the smallest community banks by other, slightly larger community banks. See Michelle W. Bowman, Member, Bd. of Governors of the Fed. Rsrv. Sys., Remarks at the 2019 Community Banking Research and Policy Conference: Advancing Our Understanding of Community Banking 4 (Oct. 1, 2019), https://www. federalreserve.gov/newsevents/speech/files/bowman20191001a.pdf [https://perma.cc/6UYE-CE62]; see also Michal Kowalik, Troy Davig, Charles S. Morris \& Kristen Regehr, Bank Consolidation and Merger Activity Following the Crisis, 100 FED. RSRv. BANK Kan. City ECON. REV., no. 1, 2015, at 31, 35 (describing the characteristics of acquired banks); Adam R. Lewis, North Carolina Community Banks: Survival Strategies for Turbulent Times, 17 N.C. BANKING INST. 333, 349-51 (2013) (articulating the benefits of community bank mergers).

${ }^{180}$ See Bowman, supra note 179, at 9.

${ }^{181}$ See id.; Jeremy C. Kress, Modernizing Bank Merger Review, 37 YALE J. ON REG. 435, 459-60 (2020).

${ }^{182}$ Bowman, supra note 179 , at 5-6; Kowalik et al., supra note 179 , at 45 . When the acquiring community banks continue to operate their target's former branches, therefore, borrowers in economically vulnerable communities retain access to relational lending, but now through more stable and sophisticated banks.

${ }^{183}$ Moreover, to the extent that community bank consolidation has undesirable consequences for underbanked areas, these effects could be addressed through more effective bank-merger oversight, 
Third, the claim that a level playing field — without subsidies—would expose community banks to competitive pressures and threaten the supply of relational lending rests on a misconception. The legal scholarship repeatedly insists that "[c]ommunity banks have compiled a superior record of meeting the needs of their customers while maintaining a stable business model." 184 But in a market economy, superior business models do not succumb to competitive pressures; they are the source of those pressures on inferior models. If there is special value added from relational lending services - and there is good reason to believe that is the case ${ }^{185}$ - then firms that provide those services will be able to sustain market share and turn a profit without subsidization. That basic economic intuition is consistent with data on community banks' financial performance surveyed above, which confirm that their business model continues to compete quite well. ${ }^{186}$

Legal scholars' entreaties to subsidize community banks are therefore unpersuasive. Artificially propping up the community bank sector is not a viable solution to the too-big-to-fail problem. Nor are community bank subsidies essential to protect underbanked areas or to preserve access to relational lending services. Calls to further subsidize community banks therefore suffer from the same analytical deficiencies as the movement to deregulate them.

instead of subsidies. See, e.g., Press Release, Senator Warren and Representative García Announce Introduction of the Bank Merger Review Modernization Act to End Rubber Stamping of Bank Merger Applications (Dec. 4, 2019), https://www.warren.senate.gov/newsroom/press-releases/senator-warrenand-representative-garca-announce-introduction-of-the-bank-merger-review-modernization-act-to-endrubber-stamping-of-bank-merger-applications [https://perma.cc/TUF2-WHRX] (proposing that, among other requirements, bank-merger applicants enter enforceable community benefits plans to mitigate harmful consequences in underserved areas).

184 Wilmarth, supra note 22, at 255, 289, 299 (asserting that customer satisfaction is higher at community banks); see also Spivey, supra note 171, at 127 (discussing the advantages of relational lending for small businesses and communities). Professor Wilmarth touts the stability of community banks, while nonetheless noting that 450 such institutions failed during the financial crisis. Wilmarth, supra note 22 , at 254 . Part of that collapse, Wilmarth argues, was due to community banks' heavy investment in risky commercial real estate loans, which experienced a "sudden" and "disastrous" collapse in 2007. Id. at 279-80.

${ }^{185}$ See, e.g., Allen N. Berger \& Lamont K. Black, Bank Size, Lending Technologies, and Small Business Finance, 35 J. BANKING \& FIN. 724, 735 (2011) (discussing the advantages of relational lending by small banks).

${ }^{186}$ One possible exception may be banks that have stagnated at the very smallest size threshold. See supra Section I.A.1; see also supra note 151 and accompanying text. 
In sum, community banks do not necessitate special legal treatment. Notwithstanding the weak justifications for community bank deregulation, however, policymakers have eagerly taken up the cause. As the next Part explains, recent ill-conceived community bank regulatory rollbacks are likely to undermine community banks' safety and soundness and amplify the too-many-to-fail problem.

\section{The MisGuided DEREgUlation OF COMMUNITY BANKS}

Even before the initial wave of post-financial crisis reforms had been fully implemented, policymakers embarked on a campaign to alleviate purported regulatory burdens on community banks. These efforts culminated in 2018 with the EGRRCPA and related deregulatory initiatives. ${ }^{187}$ Among other things, Congress and the federal financial agencies weakened community bank capital rules, liquidity requirements, and supervisory oversight. At the time, few policymakers questioned the wisdom of these rollbacks. To the contrary, legislators from across the political spectrum supported looser restrictions on community banks. ${ }^{188}$ These policymakers failed to appreciate, however, the potential systemic risks associated with deregulating smaller depository institutions.

This Part contends that the EGGRCPA and associated regulatory rollbacks will increase financial stability risks in four ways. First, community banks are now free to invest in more volatile assets because the EGGRCPA exempts them from risk-based capital requirements and the Volcker Rule. Second, smaller depository institutions may now rely on more runnable funding sources due to reforms that weaken longstanding restrictions on risky brokered deposits. Third, supervisors will be less likely to detect unsafe practices because of relaxed community bank oversight. Finally, private equity funds, hedge funds, and other institutional investors are likely to take advantage of looser corporate governance restrictions to steer community banks toward riskier business strategies. Taken together, these legal changes will exacerbate the fragility of the community bank sector and hasten another too-many-to-fail crisis.

\section{A. Riskier Assets}

One of the primary consequences of recent regulatory rollbacks is that community banks will be free to invest in riskier and more volatile assets.

\footnotetext{
${ }^{187}$ Economic Growth, Regulatory Relief, and Consumer Protection Act, Pub. L. No. 115-174, 132 Stat. 1296 (2018).

${ }^{188}$ See, e.g., Rebeca Romero Rainey, Opinion, Community Banks a Bipartisan Touchstone for New Congress, HILl (Nov. 19, 2018, 8:20 AM), https://thehill.com/blogs/congress-blog/politics/417373community-banks-a-bipartisan-touchstone-for-new-congress [https://perma.cc/XU5C-QWA7].
} 
New statutory exemptions from two fundamental postcrisis reforms-Basel III's risk-based capital requirements and the Volcker Rule's prohibition on speculative investments - remove important constraints on community banks' investment portfolios. This Section examines each of these reforms in turn.

\section{Community Bank Leverage Ratio}

The most significant way Congress and the regulatory agencies have relaxed community bank regulation is by dramatically overhauling the capital requirements that apply to such firms. Community banks have long urged policymakers to simplify post-financial crisis capital rules that they insist are excessively complicated. ${ }^{189}$ By completely eliminating risk-based capital requirements for most community banks, however, the EGRRCPA goes far beyond the modest changes that the small-bank lobby proposed. This sweeping rollback is unwarranted because it will incentivize community banks to make excessively risky investments to a degree that cannot be justified by any compliance-cost rationale.

Traditionally, U.S. banks have been subject to two different types of capital standards: (1) a leverage ratio, and (2) risk-based capital requirements. ${ }^{190}$ The leverage ratio is the more straightforward of the two rules. A bank calculates its leverage ratio by simply dividing its capital by its total assets. ${ }^{191}$ Historically, a minimum leverage ratio has been the dominant policy tool for assessing U.S. banks' capital adequacy, with the first federal leverage requirement dating back to the 1930s. ${ }^{192}$ Today, U.S. banks must maintain a ratio of tier 1 capital to total assets of at least $4 \% .{ }^{193}$

\footnotetext{
189 See infra notes 200-202 and accompanying text.

${ }^{190}$ In general, bank capital is analogous to equity. See BARR ET AL., supra note 62, at 265-67. Thus, the more capital that a bank maintains, the less likely it is to become insolvent and inflict losses on depositors, other creditors, and the banking system as a whole. See id. Banks, however, typically prefer to fund themselves with debt, which receives more favorable tax treatment and other legal advantages compared to equity. $C f$. Anat R. Admati, Peter M. DeMarzo, Martin F. Hellwig \& Paul Pfleiderer, Fallacies, Irrelevant Facts, and Myths in the Discussion of Capital Regulation: Why Bank Equity Is Not Socially Expensive 19-21 (Rock Ctr. for Corp. Governance, Working Paper No. 161, 2013), https://www.gsb.stanford.edu/gsb-cmis/gsb-cmis-download-auth/311031 [https://perma.cc/3BC5-

K5DA] (noting that debt is cheaper than equity because of tax subsidies). As a result, banks favor lower capital requirements to minimize their funding costs while maximizing their shareholders' return on equity. See Anat Admati \& Martin Hellwig, The Bankers' New Clothes: What's Wrong with BANKING AND WHAT TO Do ABOUT IT 97-99 (2013) (challenging the validity of banks' claims that "higher capital requirements would 'greatly diminish growth"”).

${ }^{191}$ See BARR ET AL., supra note 62, at 280.

192 See id. at 267

19312 C.F.R. $\S \S 3.10$ (a)(1)(iv), 217.10(b)(4), 324.10(b)(4) (2019). Tier 1 capital consists of common stock, retained earnings, paid-in capital, and certain hybrid securities. See id. $\S \S 3.20$ (b)-(c), 217.20(b)(c), 324.20(b)-(c).
} 
Since the adoption of the first Basel Accord (Basel I) in 1988, the United States has required its banks to satisfy risk-based capital standards in addition to the leverage requirement. A risk-based capital ratio differs from a leverage ratio in that banks must risk-weight their assets, with investments perceived as more volatile receiving a higher weight. ${ }^{194}$ Accordingly, banks that hold riskier assets must maintain commensurately more capital to meet minimum risk-based capital requirements. In 2013, the United States implemented Basel III, which strengthened the precrisis risk-based capital framework and increased the amount of capital banks must maintain. ${ }^{195}$ Among other Basel III requirements, U.S. regulators now mandate that domestic banks maintain a ratio of tier 1 capital to risk-weighted assets of at least $6 \%{ }^{196}$

Risk-based capital and leverage requirements work in tandem to ensure that a bank maintains an appropriate cushion against unexpected losses. ${ }^{197} \mathrm{~A}$ risk-based approach requires that banks with higher-risk profiles maintain bigger capital cushions than banks that invest primarily in safer assets. In isolation, however, risk-based capital standards allow banks to "game the system" by selectively investing in the riskiest assets within each risk-weight category ${ }^{198}$ A simple leverage ratio is typically viewed as a backstop to riskbased capital requirements that prevents firms from engaging in this sort of regulatory arbitrage. ${ }^{199}$ Thus, risk-based capital and leverage requirements work together as a belt-and-suspenders approach to ensure bank safety and soundness.

${ }^{194}$ For example, under Basel I's relatively rudimentary risk-weights, a U.S. Treasury bond was riskweighted at $0 \%$, while a commercial loan was risk-weighted at $100 \%$. BASEL COMM. ON BANKING SuPERVISION, INTERNATIONAL CONVERGENCE OF CAPITAL MEASUREMENT AND CAPITAL STANDARDS 17-18 (1988), http://www.bis.org/publ/bcbsc111.pdf [https://perma.cc/BK8S-6Q7Y]. For further background on risk-based capital requirements, see Julie Andersen Hill, Bank Capital Regulation by Enforcement: An Empirical Study, 87 IND. L.J. 645, 650-56 (2012).

195 See Regulatory Capital Rules: Regulatory Capital, Implementation of Basel III, 78 Fed. Reg. 62018 (Oct. 11, 2013) (codified in scattered sections of 12 C.F.R.).

19612 C.F.R. $\$ \S 3.10$ (a)(ii), 217.10(a)(ii), 324.10(a)(ii). Banks also must maintain a common equity tier 1 capital ratio of at least $4.5 \%$ and a total capital ratio of at least $8 \%$. See id. $\S \S 3.10$ (a)(i), (iii), 217.10(a)(i), (iii), 324.10(a)(i)-(iii).

197 See Matthew C. Turk, Overlapping Legal Rules in Financial Regulation and the Administrative State, 54 GA. L. REV. 791, 830, 836-37 (2020).

198 See id.; see also Aaron D. Klein, Risk Weights or Leverage Ratio? We Need Both, AM. BANKER (Dec. 20, 2016, 8:30 AM), https://www.americanbanker.com/opinion/risk-weights-or-leverage-ratio-weneed-both [https://perma.cc/E3J9-C4WT] (discussing strengths and weaknesses of risk-based capital standards relative to leverage rules).

199 See Daniel K. Tarullo, Banking on Basel: The Future of International Financial REGULATION 265-68 (2008) 
Community banks have frequently objected to this two-pronged approach — particularly the Basel III risk-based capital requirements — on the ground that the new capital framework is excessively complex for smaller institutions. ${ }^{200}$ Policymakers have been receptive to these complaints. According to FDIC Chairwoman Jelena McWilliams, for example, the "Basel III standards . . . are unduly complex and unnecessary for community banks." ${ }^{201}$ Thus, soon after Basel III's implementation, ICBA recommended that policymakers should replace the new risk-based capital standards for community banks with the simpler Basel I framework. ${ }^{202}$

In response, Congress substantially overhauled community bank capital requirements in the EGRRCPA. In doing so, however, lawmakers went considerably further than restoring the Basel I risk-based capital requirements, as ICBA had recommended. Instead, § 201 of the EGRRCPA establishes a community bank leverage ratio (CBLR) to be set between $8 \%$ and $10 \%$ at the federal bank regulators' discretion. ${ }^{203}$ The EGRRCPA also states that a bank with less than $\$ 10$ billion in total assets will be considered to have met all applicable leverage and risk-based capital requirements if it exceeds the CBLR. ${ }^{204}$ Thus, the EGRRCPA effectively eliminates all riskbased capital requirements for community banks that satisfy the CBLR. The federal banking agencies set the CBLR at $9 \%$ in late $2019 .{ }^{205}$

200 The ICBA, for example, contended that complicated Basel III risk-based capital requirements "harm[] the consumers and businesses that rely on community bank credit." Bank Capital and Liquidity Regulations Part II: Industry Perspectives: Hearing Before the S. Comm. on Banking, Hous., \& Urb. Affs., 114th Cong. 28 (2016) [hereinafter Bank Capital Hearing] (prepared statement of Rebeca Romero Rainey, Chairman and Chief Executive Officer, Centinel Bank of Taos). One community bank executive testified that his firm hired two separate commercial vendors to assign risk-weights to its investments and spent up to fifty hours per quarter reconciling differences between the two providers. See Legislative Proposals for a More Efficient Federal Financial Regulatory Regime: Part III: Hearing Before the Subcomm. on Fin. Insts. \& Consumer Credit of the H. Comm. on Fin. Servs., 115th Cong. 67 (2018) (statement of Robert M. Fisher, President and Chief Executive Officer, Tioga State Bank) [hereinafter Fisher Testimony].

201 Jelena McWilliams, Chairman, FDIC, Remarks at the Federal Reserve Bank of Chicago Thirteenth Annual Community Bankers Symposium: Back to Basics (Nov. 16, 2018), https://www.fdic. gov/news/news/speeches/spnov1618.html [https://perma.cc/V8R7-MZAE].

${ }^{202}$ See Bank Capital Hearing, supra note 200, at 4 (statement of Rebeca Romero Rainey, Chairman and Chief Executive Officer, Centinel Bank of Taos).

${ }^{203}$ See Economic Growth, Regulatory Relief, and Consumer Protection Act, Pub. L. No. 115-174, $\S 201$ (b), 132 Stat. 1296, 1306 (2018) (codified at 12 U.S.C. § 5371(b) (Capital Simplification for Qualifying Community Banks)).

${ }^{204}$ See id. $\S 201(\mathrm{a})(3)$, (c).

${ }^{205}$ See Regulatory Capital Rule: Capital Simplification for Qualifying Community Banking Organizations, 84 Fed. Reg. 61776 (Nov. 13, 2019) (to be codified in scattered sections of 12 C.F.R.) [hereinafter CBLR Final Rule]. In response to the COVID-19 pandemic, Congress temporarily reduced the CBLR to $8 \%$ until the earlier of: (1) the termination of the national emergency declaration related to 
Proponents of the CBLR assert that eliminating risk-based capital requirements will ease regulatory burden on community banks. They claim, for example, that small banks that lack the expertise to calculate their own risk-based capital ratios will no longer need to hire outside consultants to assign risk-weights to their assets. ${ }^{206}$ Moreover, according to FDIC Chairman McWilliams, community banks will be able to demonstrate compliance with the CBLR by completing just one page of regulatory reporting, compared to fifteen pages for risk-based capital requirements. ${ }^{207}$ Thus, the primary rationale for the CBLR is grounded in easing the administrative burden on community banks.

In their effort to provide community banks regulatory relief, however, policymakers failed to appreciate how the CBLR framework undermines the safety and soundness of community banks that opt in to it. When subject only to a leverage requirement, a community bank's investments are treated identically for regulatory capital purposes, regardless of their underlying risk profile. As former Federal Reserve Governor Daniel Tarullo explained, "[W]ith the constraints of risk-based capital... lifted, [banks will] be strongly incentivized to change the composition of their balance sheets dramatically, shedding safer and more liquid assets like Treasuries in exchange for riskier but higher-yielding assets." ${ }^{208}$ It is for precisely this reason that policymakers originally supplemented the leverage ratio requirement with risk-based capital requirements in the 1980s. ${ }^{209}$

In response to the CBLR, therefore, community banks are likely to increase their risk profiles in an effort to generate higher returns. Postfinancial crisis regulation has demonstrated that financial assets migrate to

the COVID-19 pandemic, or (2) December 31, 2020. Coronavirus Aid, Relief, and Economic Security Act, Pub. L. No. 116-136, § 4012, 134 Stat. 281, 479 (2020). The financial regulatory agencies issued an interim final rule outlining a transition back to a $9 \%$ CBLR by January 1, 2022. See Regulatory Capital Rule: Transition for the Community Bank Leverage Ratio Framework, 85 Fed. Reg. 22930 (Apr. 23, 2020) (to be codified in scattered sections of 12 C.F.R.).

${ }^{206}$ See supra note 200.

207 Jelena McWilliams, Chairman, FDIC, Oversight of Prudential Regulators: Ensuring the Safety, Soundness, and Accountability of Megabanks and Other Depository Institutions (May 16, 2019), https://www.fdic.gov/news/news/speeches/spmay1619.html [https://perma.cc/32KT-TUGX].

${ }^{208}$ Daniel K. Tarullo, Member, Bd. of Governors of the Fed. Rsrv. Sys., Departing Thoughts: Speech at the Woodrow Wilson School 11-12 (Apr. 4, 2017), https://www.federalreserve.gov/newsevents/ speech/files/tarullo20170404a.pdf [https://perma.cc/YY5R-B6W5]; see also Mike Konczal, Why Banking Leverage Requirements Are Not Enough, RoOSEVELT INST., (Mar. 16, 2017), https:// rooseveltinstitute.org/why_we_need_both_capital_requirements/ [https://perma.cc/K3LM-EUER] (noting that, in the absence of risk-based capital standards, a leverage requirement incentivizes banks to invest in riskier assets).

209 See Tarullo, supra note 208, at 11-12. 
institutions where they are subject to comparatively lower capital charges. ${ }^{210}$ This dynamic will likely accelerate following the implementation of the CBLR, as community banks invest in risky assets that would be subject to high capital charges if held by banks that are subject to risk-based capital requirements.

Moreover, contrary to some claims, it is unlikely that increased risktaking occasioned by the CBLR will be offset by higher overall capital levels among community banks. CBLR proponents insist that the new leverage ratio will make community banks safer by elevating the total amount of capital in the banking system. ${ }^{211}$ Since the 9\% CBLR exceeds the tier 1 leverage ratio of $4 \%$, supporters assume that community banks will need to maintain more capital in order to qualify for the exemption from risk-based capital requirements. ${ }^{212}$ However, this assumption is inaccurate. The vast majority of community banks have traditionally maintained leverage ratios well above the $4 \%$ minimum in order to satisfy risk-based capital requirements that are more stringent than the leverage ratio backstop. Indeed, the federal banking agencies estimate that $85 \%$ percent of eligible community banks already maintain a tier 1 leverage ratio greater than $9 \%$ and therefore will not need to raise capital in order to take advantage of the CBLR. ${ }^{213}$ Thus, while the 9\% CBLR strengthens the leverage requirement for community banks, in practice, the elimination of risk-based requirements may nonetheless allow small banks to take on greater overall balance sheet risk without commensurately increasing their capital.

In sum, moving to a solely leverage-based capital regime will incentivize community banks to invest in higher-yielding-and therefore riskier - assets. The push to eliminate community banks' risk-based capital requirements in the EGRRCPA, however, ignored this likely outcome. Thus,

${ }^{210}$ See, e.g., John Heltman, Regulators Need More Tools to Keep System Safe: Boston Fed Chief, AM. BANKER (July 15, 2019, 9:30 PM), https://www.americanbanker.com/news/regulators-need-moretools-to-keep-system-safe-boston-fed-chief [https://perma.cc/6WWB-WF6G] (noting that commercial real estate has migrated from big banks subject to the Federal Reserve's stress tests to smaller banks that are not subject to such tests). For further discussion of the regulatory arbitrage phenomenon, see infra Section I.A.

${ }^{211} C f$. Press Release, Indep. Cmty. Bankers of Am., ICBA Statement on Community Bank Leverage Ratio (Nov. 20, 2018), https://www.icba.org/news/icba-in-the-news/2018/11/20/icba-statement-oncommunity-bank-leverage-ratio [https://perma.cc/LM25-B9XZ] (“[The proposed CBLR] would be well over the 5 percent leverage ratio requirement currently required of all well-capitalized banks and significantly higher than next year's requirement of 7 percent common equity over total risk-based assets ...."); Letter from Sen. Mike Crapo et al., to Jerome H. Powell, Chairman, Bd. of Governors of the Fed. Rsrv. Sys. (July 30, 2019), https://www.banking.senate.gov/imo/media/doc/Powell\%20Otting\% 20McWilliams\%20Letter\%207-30-19.pdf [https://perma.cc/KY3R-24LM] ("The proposed 9 percent CBLR is well above the current Tier 1 leverage requirement for well-capitalized banks.").

${ }^{212}$ See supra note 211.

${ }^{213}$ See CBLR Final Rule, supra note 205, at 61784. 
while the CBLR simplifies the capital regime, it does so at the expense of community banks' safety and soundness.

\section{The Volcker Rule}

A second way in which the EGGRCPA permits community banks to invest in riskier assets is by exempting them from the Volcker Rule. Congress originally adopted the Volcker Rule to prevent banks and bank holding companies (BHCs) from using insured deposits to speculate in financial markets. By exempting small firms from the Volcker Rule, policymakers have now unwisely exposed the community bank sector to renewed risk-taking.

Enacted in 2010 as one of the centerpieces of Dodd-Frank, the Volcker Rule sought to eliminate speculative trading activities from the regulated banking sector. As the chief architect of the rule, former Federal Reserve Chairman Paul Volcker, warned Congress, "[I]f banking institutions . . . are given free rein to speculate, I may not live long enough to see the crisis, but my soul is going to come back and haunt you." 214 Heeding Volcker's warning, Congress adopted the Volcker Rule, which contains two substantive prohibitions. ${ }^{215}$ First, the Volcker Rule bars banks and BHCs from engaging in proprietary trading - using the firm's funds to buy or sell financial instruments for its trading account. ${ }^{216}$ Second, the Volcker Rule restricts these institutions from investing in or sponsoring hedge funds and private equity funds that would effectively undertake the same activities. ${ }^{217}$ As originally adopted in the Dodd-Frank Act, these prohibitions applied to all banks and BHCs, regardless of size.

Upon Dodd-Frank's enactment, community banks argued that applying the Volcker Rule to small banks was unnecessary because they generally do not engage in proprietary trading or invest in covered funds. ${ }^{218}$ Community banks also claimed that the Volcker Rule imposed significant regulatory costs because they would have to hire consultants and lawyers to

${ }^{214}$ Prohibiting Certain High-Risk Investment Activities by Banks and Bank Holding Companies: Hearing Before the S. Comm. on Banking, Hous., \& Urb. Affs., 111th Cong. 28 (2010) (statement of Paul A. Volcker, Chairman, President's Economic Recovery Advisory Board.).

${ }^{215}$ For background on the Volcker Rule, see S. Burcu Avci, Cindy A. Schipani \& H. Nejat Seyhun, Eliminating Conflicts of Interests in Banks: The Significance of the Volcker Rule, 35 YALE J. ON REG. 343, 363-68 (2018), and Ryan Bubb \& Marcel Kahan, Regulating Motivation: A New Perspective on the Volcker Rule, 96 TEX. L. REV. 1019, 1023-28 (2018).

21612 U.S.C. $\S 1851(\mathrm{a})(1)(\mathrm{A}),(\mathrm{h})(4)$.

${ }^{217}$ Id. § 1851(a)(1)(B).

${ }^{218}$ See Butz, supra note 22, at 465. 
demonstrate compliance with the rule. ${ }^{219}$ Eventually, even some Dodd-Frank supporters-including Federal Reserve Governor Daniel Tarulloconcluded that community banks should not be covered by the Volcker Rule. ${ }^{220}$

In response to this pressure, Congress exempted community banks from the Volcker Rule in the EGRRCPA. As amended by the EGRRCPA, the Volcker Rule does not apply to a bank or BHC with $\$ 10$ billion or less in total consolidated assets, as long as the firm's trading assets and trading liabilities are less than $5 \%$ of its total assets. ${ }^{221}$ The federal banking agencies finalized corresponding amendments to the Volcker Rule's implementing regulations in mid-2019.222

While the community bank exemption might appear innocuous, removing the Volcker Rule's constraints is likely to lead to escalating risks within the community bank sector. To be sure, few community banks engaged in proprietary trading or invested in hedge funds and private equity funds before Dodd-Frank. ${ }^{223}$ But as the financial sector equilibrates in the post-EGRRCPA regulatory environment, community banks now hold a unique regulatory permit to engage in those activities, which are off-limits to bigger banks. The precrisis landscape is therefore misleading. The dynamic effect of the Volcker Rule exemption will be to encourage at least some community banks to engage in speculative activity, even if they did not before the Volcker Rule was enacted. ${ }^{224}$

In practice, the EGRRCPA's Volcker Rule exemption permits community banks to amass significant risks in two ways. First, even though Congress capped community banks' trading exposures at 5\% of their

${ }^{219}$ See Letter from Christopher Cole, Exec. Vice President \& Senior Regul. Counsel, Indep. Cmty. Bankers of Am., to Legis. \& Regul. Activities Div., Off. of the Comptroller of the Currency 2 (Sept. 19, 2017), https://www.icba.org/docs/default-source/icba/advocacy-documents/letters-to-regulators/2017/ c1091917.pdf [https://perma.cc/Z7SM-VTNM]. Although the financial regulatory agencies tried to tailor the rule's requirements for community banks to limit compliance costs, these accommodations did not fully alleviate the burden. See Tarullo, supra note 208, at 8 ("While the regulatory agencies have tried to tailor the rules so as to avoid burdening [community] banks, even the process of figuring out that the rules do not constrain them is a compliance cost ....").

${ }^{220}$ See Tarullo, supra note 208, at 7 ("[T] than is necessary to achieve its purpose .... [T] he concerns underlying the Volcker rule are simply not an issue at community banks.").

22112 U.S.C. $\S 1851(\mathrm{~h})(1)(\mathrm{B})$.

${ }^{222}$ Revisions to Prohibitions and Restrictions on Proprietary Trading and Certain Interests in, and Relationships with, Hedge Funds and Private Equity Funds, 84 Fed. Reg. 35008 (July 22, 2019) (codified in scattered sections of 12 C.F.R. and 17 C.F.R.).

${ }^{223}$ See Peirce et al., supra note 104 , at 45 (noting that only $0.6 \%$ of community banks modified their activities in response to the Volcker Rule).

${ }^{224}$ For more on the regulatory arbitrage phenomenon, see infra Section I.A. 
assets, ${ }^{225}$ this limitation still permits a significant amount of proprietary trading. Indeed, $5 \%$ of assets exceeds the minimum leverage ratio requirement for community banks that do not opt in to the CBLR. ${ }^{226}$ Thus, as a result of the EGRRCPA, a community bank may now invest an amount equal to its entire equity cushion in potentially volatile financial assets that are forbidden to larger banks. ${ }^{227}$

The second way in which the Volcker Rule exemption exposes community banks to increasing risk is by allowing such firms to make unlimited investments in hedge funds and private equity funds. Although the EGRRCPA capped community banks' trading exposures at 5\% of total assets, policymakers did not limit community banks' investments in hedge funds or private equity funds. ${ }^{228}$ In many respects, this loophole eviscerates the $5 \%$ limit on trading exposures because hedge funds' sole function is to engage in proprietary trading. Several law firms have already begun encouraging community banks to exploit this loophole by investing in previously prohibited funds, ${ }^{229}$ even though such funds tend to specialize in highly volatile asset markets, do not have an impressive financial track record, and therefore threaten to impose significant losses on the banks that invest in them..$^{230}$

In sum, there are reasons to believe that releasing smaller firms from the Volcker Rule's prohibitions could contribute to escalating risks in the community bank sector. When rolling back the Volcker Rule, policymakers focused exclusively on the benefits of the reducing compliance burden on community banks. What they missed, however, is that proprietary trading and investments in hedge funds and private equity funds will likely migrate

22512 U.S.C. $\S 1851(\mathrm{~h})(1)(\mathrm{B})$

226 See supra note 193 and accompanying text.

${ }^{227}$ Moreover, as FDIC Board Member and former Chairman Martin Gruenberg noted, the 5\% limitation on trading account assets is not a meaningful constraint, since "a bank can engage in proprietary trading from its available-for-sale account as easily as it can from its trading account." Martin J. Gruenberg, Member, FDIC, Statement at Meeting of the FDIC Board of Directors: Notice of Proposed Rulemaking: Volcker Rule Small Bank Exemption 2 (Dec. 18, 2018), https://www.fdic.gov/news/news/ speeches/spdec1818a.pdf [https://perma.cc/DHA3-3UGS].

${ }^{228} \mathrm{See} i d$. (arguing that the $5 \%$ trading-exposure limit has minimal practical effect because community banks may still invest in hedge funds and private equity funds).

229 See Deborah J. Enea, Jonathan D. Hammond \& Elizabeth R. Glowacki, Troutman Pepper Hamilton Sanders LlP, Final Volcker Rule Regulation Eases Hedge Fund and PRIVATE EQUITY FUND RESTRICTIONS 4 (2019), https://www.troutman.com/print/content/37314/FinalVolcker-Rule-Regulation-Eases-Hedge-Fund-And-Private-Equity-Fund-Restrictions.pdf [https:// perma.cc/BN7U-XLUQ] ("[T]he increased scope and flexibility in trading activities [that community banks] now have will make them attractive partners in private equity funds and hedge funds ....").

${ }^{230}$ See, e.g., LowENSTEIN, supra note 45, at 185-218 (discussing collapse of hedge fund Long-Term Capital Management). 
to community banks now that such conduct is permissible only for smaller firms. As a result of the Volcker Rule exemption, therefore, community banks will be increasingly exposed to these volatile investments.

\section{B. More Volatile Funding}

In addition to relaxing restrictions on community banks' investments, policymakers have also eased limits on their use of risky funding sources. Traditionally, U.S. banks faced restrictions on the extent to which they could accept funds from deposit brokers-intermediaries that facilitate the placement of account-holders' money with insured depository institutions. ${ }^{231}$ The EGRRCPA, however, allows community banks to rely increasingly on brokered deposits, despite evidence that such funds are uniquely prone to withdrawal during a crisis. ${ }^{232}$ These reforms will render community banks more susceptible to destabilizing runs by their creditors.

U.S. banks fund themselves primarily with deposits, but the nature of a bank's deposits may vary dramatically. The most common type of deposits - core deposits - come from a bank's local customers who have a borrowing relationship with the bank. ${ }^{233}$ Core deposits are subject to the FDIC deposit insurance limit — currently $\$ 250,000$ per customer, per bank. ${ }^{234}$ Since the 1960s, however, deposit brokers have helped businesses and highnet-worth individuals spread their accounts among multiple banks in order to maximize their deposit insurance protection and obtain higher interest rates. ${ }^{235}$ Thereafter, a new subset of brokered deposits soon emerged, called reciprocal deposits, in which banks form a network to trade high-dollar deposits among themselves - with the help of a broker-so that their customers receive insurance coverage on the entire amount of their deposits. ${ }^{236}$ By 2018 , nearly $\$ 1$ trillion-or $8 \%$ of the total deposits in U.S. banks - had been placed through deposit brokers. ${ }^{237}$

\footnotetext{
${ }^{231}$ See FDIC, Study on CORE Deposits AND BRoKered Deposits 6-7 (2011) [hereinafter BROKERED DEPOSIT STUDY], https://www.fdic.gov/regulations/reform/coredepositstudy.pdf [https://perma.cc/AV4F-XKX9].

${ }^{232}$ See id. at 47-48 (summarizing evidence of risks associated with brokered deposits).

233 See id. at 5; see also Unsafe and Unsound Banking Practices: Brokered Deposits and Interest Rate Restrictions, 84 Fed. Reg. 2366, 2377-78 (proposed Feb. 6, 2019) [hereinafter Brokered Deposit Advanced Notice of Proposed Rulemaking].

${ }^{234}$ See 12 U.S.C. $\S 1821$ (a)(1) (providing that the FDIC shall insure depositors up to $\$ 250,000$ per ownership account category, per depositor, per institution).

${ }^{235}$ See Brokered Deposit Advanced Notice of Proposed Rulemaking, supra note 233, at 2368.

${ }^{236}$ See id. at 2368-69.

${ }^{237} I d$. at 2379 (listing these data points as of September 30, 2018).
} 
In response to this trend, policymakers have limited banks' ability to accept brokered deposits. Critics warn that banks might use brokered deposits to grow rapidly and without adequate risk controls, as some firms did in the lead-up to the 1980s S\&L crisis. ${ }^{238}$ Moreover, policymakers fear that brokered deposits are more volatile than core deposits, because customers without a direct relationship to a bank might be more likely to withdraw their funds when they become aware of problems at the bank or when they find a better interest rate offered elsewhere. ${ }^{239}$ As a result, Congress established the first restrictions on brokered deposits in 1989. ${ }^{240}$ Today, a bank that does not satisfy minimum capital requirements is prohibited from accepting brokered deposits, and a bank that is not "well capitalized" may take brokered deposits only if it obtains a waiver from the FDIC. ${ }^{241}$ In addition, a bank must pay higher deposit insurance premiums if brokered deposits comprise more than $10 \%$ of its total deposits. ${ }^{242}$

Community banks have long argued that these restrictions on brokered deposits are excessive and are particularly disadvantageous for small banks. One reason is that brokered deposits can be a relatively cheap way to fund asset growth compared to accepting deposits through brick-and-mortar branches. ${ }^{243}$ Community banks have been particularly critical of limitations on reciprocal deposits, which they view as an essential tool to compete with larger firms for funding. ${ }^{244}$

${ }^{238}$ See BROKERED DePOSIT STUDY, supra note 231, at 15 (discussing use of brokered deposits in the $\mathrm{S} \& \mathrm{~L}$ crisis).

239 Brokered Deposit Advanced Notice of Proposed Rulemaking, supra note 233, at 2366; BROKERED DEPOSIT STUDY, supra note 231, at 48, 50-51.

${ }^{240}$ See Financial Institutions Reform, Recovery, and Enforcement Act of 1989, Pub. L. No. 101-73, $\S 224,103$ Stat. $183,273-75$ (codified as amended at 12 U.S.C. $\S 1831 \mathrm{f}$ ).

${ }^{241}$ See 12 U.S.C. $\$ 1831 \mathrm{f}(\mathrm{a}),(\mathrm{c})$.

${ }^{242}$ See 12 C.F.R. § 327.9(d)(3) (2020).

${ }^{243}$ See Letter from Christopher Cole, Exec. Vice President \& Senior Regul. Counsel, Indep. Cmty. Bankers of Am., to Robert E. Feldman, Exec. Sec'y, FDIC 7 (May 7, 2019), https://www.icba.org/docs/default-source/icba/advocacy-documents/letters-to-regulators/19-05-07 brokereddepositcl.pdf [https://perma.cc/6LRH-35G4] ("Brokered deposits can be a stable source of funding and a cost-effective way for community banks to meet their funding needs.").

${ }^{244}$ See Victoria Guida, Why Congress Wants to Skirt the Limits on Federal Deposit Insurance, Politico (Apr. 8, 2018, 4:16 PM), https://www.politico.com/story/2018/04/08/banks-federal-depositinsurance-463705 [https://perma.cc/8YBY-M5ZG] (noting community banks' view that reciprocal deposits help them level the competitive playing field with the largest banks). Specifically, community banks pleaded with policymakers to permit small firms to rely more heavily on reciprocal deposits, claiming that reciprocal deposits are less likely than nonreciprocal brokered deposits to flee during a crisis. See id. (“[P]roponents of reciprocal deposits . . . say they shouldn't be considered brokered deposits because they pose less risk."). 
As part of the recent deregulatory push, policymakers have now significantly liberalized decades-old limitations on brokered deposits. Most notably, in the EGRRCPA, Congress exempted reciprocal deposits from the definition of brokered deposits, thereby freeing banks to participate in interbank deposit-sharing networks without regard to their capital levels and without affecting their deposit insurance assessment rates. ${ }^{245}$ This reform is most relevant to community banks, which rely on reciprocal deposits to a much greater extent than larger competitors. ${ }^{246}$ In addition to this legislative relief, the FDIC proposed in late 2019 to further relax its brokered deposits regulation by exempting certain brokers and the deposits they manage. ${ }^{247}$ The FDIC framed these exemptions as an effort to help smaller banks. ${ }^{248}$

Despite claims that loosening rules on brokered deposits will help community banks, these reforms will in fact expose smaller firms to new funding vulnerabilities. For example, a 2011 FDIC study concluded that greater reliance on brokered deposits is associated with higher probability of bank failure. ${ }^{249}$ The same study demonstrated that, controlling for bank size, firms with more brokered deposits inflict bigger losses on the FDIC's insurance fund when they collapse. ${ }^{250}$ Moreover, brokered deposits may be

${ }^{245}$ See Economic Growth, Regulatory Relief, and Consumer Protection Act, Pub. L. No. 115-174, $\S 202$ (a), 132 Stat. 1296, 1307-08 (2018) (codified at 12 U.S.C. § 1831f(i)(1)). The reciprocal deposit exemption is capped at the lesser of $\$ 5$ billion per bank or $20 \%$ of the bank's total liabilities. Id.

${ }^{246}$ See Brokered Deposit Advanced Notice of Proposed Rulemaking, supra note 233, at 2382 chart 7 (demonstrating that reciprocal deposits constituted a significantly higher percentage of brokered deposits at smaller banks compared to larger banks).

${ }^{247}$ See Unsafe and Unsound Banking Practices: Brokered Deposits Restrictions, 85 Fed. Reg. 7453, 7458-59 (Feb. 10, 2020), https://www.fdic.gov/news/board/2019/2019-12-12-notice-dis-b-fr.pdf [https://perma.cc/4NGB-FSGJ] (proposing to expand the exception for brokers whose primary purpose is not the placement of funds with depository institutions). According to FDIC Board Member and former Chairman Martin Gruenberg, "While we cannot with confidence estimate the amount of deposits that could qualify for this exception, it seems likely to be large ...." Martin J. Gruenberg, Member, FDIC, Statement at Meeting of the FDIC Board of Directors: Notice of Proposed Rulemaking on Brokered Deposits 6 (Dec. 12, 2019), https://www.fdic.gov/news/news/speeches/spdec1219c.pdf[https://perma.cc/ GX8R-NVHX].

${ }^{248}$ See Jelena McWilliams, Chairman, FDIC, Keynote Remarks at the Brookings Institution: Brokered Deposits in the Fintech Age 6 (Dec. 11, 2019), https://www.fdic.gov/news/news/speeches/ spdec1119.pdf [https://perma.cc/LBF2-BYP9] ("[M]any banks located in low-income areas ... depend on deposits sourced from outside their local areas for funding. The changes we are considering to the brokered deposits regulation are intended to help such ... firms.").

${ }^{249}$ BROKERED DEPOSIT STUDY, supra note 231, at 3, 38-42, 47-48. Although reciprocal deposits might not be as risky as nonreciprocal brokered deposits, the FDIC found that reciprocal deposits pose more risk than core deposits. See id. at 44-46.

${ }^{250}$ See id. at 3, 42. During the 2008 financial crisis, nearly fifty banks that relied heavily on brokered deposits failed. While these institutions held assets representing $13 \%$ of all banks that failed in the crisis, they accounted for $38 \%$ of losses to the FDIC's insurance fund during that period. See Brokered Deposit Advanced Notice of Proposed Rulemaking, supra note 233, at 2370. 
particularly risky when banks use them to fund volatile or illiquid assetssuch as those incentivized by the CBLR and authorized by the Volcker Rule exemption-which can trigger fire sales when creditors unexpectedly withdraw funding. ${ }^{251}$ Similar concerns were in part what originally spurred policymakers to restrict brokered deposits in the 1980s. ${ }^{252}$ Nonetheless, the recent efforts to weaken brokered deposit restrictions have largely ignored this downside risk. ${ }^{253}$

In sum, brokered deposit reforms will allow community banks to rely on riskier sources of funding, thereby making them more vulnerable to financial distress. In lieu of stable, core deposits, more community banks will now be able to accept volatile brokered and reciprocal deposits through interbank deposit-sharing networks, despite evidence that these deposits flee quickly in times of crisis. These changes are especially worrisome when paired with reforms like the CBLR and the Volcker Rule exemption, which at the same time allow community banks to invest in riskier assets.

\section{Relaxed Supervision}

In addition to weakening community bank regulation, policymakers have also curtailed supervision of such firms by federal bank examiners. Traditionally, banks of all sizes have been subject to periodic reporting requirements and on-site examinations to verify their compliance with banking laws and regulations. ${ }^{254}$ In the last several years, however, Congress and the federal banking agencies have significantly decreased community banks' reporting obligations and examination frequency. These rollbacks ignore compelling evidence that looser bank supervision allows banks to take inappropriate risks and fail more frequently.

Supervision is the process by which government authorities oversee banks. Among other things, supervisors assess whether banks are in sound financial condition, obey safety-and-soundness rules, and abide by consumer protection requirements. ${ }^{255}$ Supervision differs from regulation, which is the

${ }^{251} C f$. Jeremy C. Kress, Patricia A. McCoy \& Daniel Schwarcz, Regulating Entities and Activities: Complementary Approaches to Nonbank Systemic Risk, 92 S. CAL. L. REV. 1455, 1471-72 (2019) (discussing fire-sale dynamics).

${ }^{252}$ See supra note 240 and accompanying text.

${ }^{253}$ See, e.g., Guida, supra note 244 (describing the brokered-deposit reform in the EGRRCPA as a "little-noticed provision").

${ }^{254}$ See, e.g., 12 U.S.C. $§ 1820$ (d) (instructing the federal banking agencies to conduct on-site examinations of insured depository institutions); $i d$. at $\$ \S 161(\mathrm{a}), 1817(\mathrm{a})-(\mathrm{b})$ (authorizing the federal banking agencies to require insured depository institutions to file periodic reports on their condition).

${ }^{255}$ See, e.g., Lev Menand, The Monetary Basis of Bank Supervision, 74 VAND. L. REV. (forthcoming 2020) (manuscript at 12-17), https://ssrn.com/a=3421232 [https://perma.cc/346L-J628]. 
process by which government agencies codify applicable rules and guidelines. ${ }^{256}$ Modern bank supervision typically takes two forms. ${ }^{257}$ First, banks are subject to periodic reporting requirements, pursuant to which they must disclose information about their financial condition.258 Second, supervisory teams conduct intermittent on-site examinations, during which they inspect a bank's books and records, meet with the bank's management, and evaluate the bank's technology and compliance systems. ${ }^{259}$

Community banks have traditionally been subject to less onerous supervision than larger banks. The United States' biggest banks, for example, are subject to continuous on-site monitoring, wherein dozens of supervisors work full-time from offices within the banks' headquarters. ${ }^{260}$ Mid-size banks, meanwhile, are subject to a twelve-month examination cycle, in which a team of supervisors visits each bank once per year to conduct an annual safety-and-soundness evaluation. ${ }^{261}$ Since 1991, however, the smallest U.S. banks have been eligible for an extended eighteen-month examination cycle. ${ }^{262}$ As of 2015 , community banks with less than $\$ 1$ billion in assets may qualify for this less frequent examination schedule. ${ }^{263}$ Community banks are likewise subject to relaxed reporting requirements. The regular Call Report - the primary form on which banks report their quarterly financial condition-contains eighty-seven pages of required data. ${ }^{264}$ In 2017, however, the financial regulatory agencies began allowing

256 Jeremy C. Kress, The Last SIFI: The Unwise and Illegal Deregulation of Prudential Financial, 71 Stan. L. ReV. ONLINE 171, 180 (2018) (distinguishing between supervision and regulation).

${ }^{257}$ See Menand, supra note 255, at 3 \& nn.2-3.

258 See BARR ET AL., supra note 62, at 899-902.

259 See id.

${ }^{260}$ See Jesse Hamilton, Plan to Stop Banks from Seducing Regulators Dies Under Trump, BLOOMBERG (Dec. 6, 2017, 8:04 AM), https://www.bloomberg.com/news/articles/2017-12-06/plan-toprevent-banks-from-seducing-regulators-dies-under-trump [https://perma.cc/M9EW-YGHE].

${ }^{261}$ See 12 U.S.C. $\S 1820(\mathrm{~d})(1)$.

${ }^{262}$ See Federal Deposit Insurance Corporation Improvement Act of 1991, Pub. L. No. 102-242, $\S 111$ (a), 105 Stat. 2236, 2240-41 (codified as amended at 12 U.S.C. § 1820(d)(4)).

${ }^{263}$ Congress originally set the eligibility threshold for the eighteen-month exam cycle at $\$ 100$ million in assets in 1991. Id. Congress increased the asset threshold to $\$ 250$ million in 1994, \$500 million in 2006, and \$1 billion in 2015. See Riegle Community Development and Regulatory Improvement Act of 1994, Pub. L. No. 103-325, § 306(a)(1), 108 Stat. 2160, 2217; Financial Services Regulatory Relief Act of 2006, Pub. L. No. 109-351, $\S 605,120$ Stat. 1966, 1981; Fixing America's Surface Transportation Act, Pub. L. No. 114-94, § 83001(1), 129 Stat. 1312, 1796 (2015).

${ }^{264}$ See Fed. Fin. Insts. EXAmination COUnCiL, Consolidated Reports of Condition AND INCOME FOR A BANK WITH DOMESTIC OFFICES ONLY_FFIEC 041 (2019), https://www.ffiec.gov/pdf/ FFIEC_forms/FFIEC041_201906_f.pdf [https://perma.cc/E5MY-KUWZ]. 
banks with less than $\$ 1$ billion in assets to file a short-form, sixty-four page Call Report to reduce their compliance burden. ${ }^{265}$

Community banks have nonetheless asserted that these accommodations provide insufficient relief from their oversight burden. In particular, community banks with more than $\$ 1$ billion in assets have urged that they should be eligible for an extended examination cycle and shortform Call Report. ${ }^{266}$ Community banks with less than $\$ 1$ billion in assets also contended that even the extended examination cycle and short-form Call Report imposed significant, unjustifiable compliance costs. ${ }^{267}$

In response to these arguments, policymakers have now curtailed community bank supervision in several ways. First, Congress expanded the field of banks eligible for lighter examination and reporting requirements in the EGRRCPA. Congress raised the eligibility threshold for the eighteenmonth examination cycle from $\$ 1$ billion to $\$ 3$ billion in assets, encompassing approximately 420 additional banks. ${ }^{268}$ Likewise, Congress authorized banks with less than $\$ 5$ billion in assets to file the short-form Call Report in the first and third quarters of each year. ${ }^{269}$ In addition, the

\footnotetext{
${ }^{265}$ See Fed. Fin. InSts. Examination COUnCil, Consolidated Reports of Condition AND INCOME FOR A BANK WITH DOMESTIC OFFICES ONLY AND TOTAL ASSETS LESS THAN \$1 BILLIONFFIEC $051 \quad$ (2019), https://www.ffiec.gov/pdf/FFIEC_forms/FFIEC051_201906_f.pdf [https://perma.cc/3WFM-ADUZ]; see also Agency Information Collection Activities: Submission for OMB Review; Joint Comment Request, 82 Fed. Reg. 2444 (Jan. 9, 2017) (adopting the short-form Call Report for banks with less than $\$ 1$ billion in assets). The short-form Call Report removed 950, or roughly $40 \%$, of the data items in the full-length Call Report, generally relating to complex or specialized investments or activities rarely applicable to community banks, such as derivatives, trading assets, and securitizations. See Proposed Agency Information Collection Activities; Comment Request, 81 Fed. Reg. 54190, 54191, 54194-98 (Aug. 15, 2016).

${ }^{266}$ See Letter from Christopher Cole, Exec. Vice President \& Senior Regul. Counsel, Indep. Cmty. Bankers of Am., to Robert deV. Frierson, Sec'y, Bd. of Governors of the Fed. Rsrv. Sys. 5, 7 (Mar. 21, 2016), https://www.icba.org/docs/default-source/icba/advocacy-documents/letters-to-regulators/2016/ c1032116.pdf [https://perma.cc/JAM2-Q723].

${ }^{267}$ For example, some community banks complained that "[p]reparations for bank exams, and the exams themselves, distract bank management from serving their communities to their full potential." Letter from Camden R. Fine, President \& Chief Exec. Off., Indep. Cmty. Bankers of Am., to John Boehner, Speaker, U.S. House of Representatives \& Nancy Pelosi, Democratic Leader, U.S. House of Representatives (Oct. 6, 2015), https://www.icba.org/docs/default-source/icba/advocacy-documents/ letters-to-congress/2015/ltr100615.pdf [https://perma.cc/4TF9-Z554]. Similarly, the ICBA maintained that "[w] hatever negligible value there is for the regulators in obtaining [Call Report data] is dwarfed by the expense and the staff hours dedicated to collecting it." Letter from Camden R. Fine, President \& Chief Exec. Off., Indep. Cmty. Bankers of Am., to Randy M. Hultgren \& Terri A. Sewell, U.S. House of Representatives (Feb. 10, 2016) (on file with journal).

26812 U.S.C. $\S 1820(d)(4)$; Expanded Examination Cycle for Certain Small Insured Depository Institutions and U.S. Branches and Agencies of Foreign Banks, 83 Fed. Reg. 43961, 43963 (Aug. 29, 2018) (codified in scattered sections of 12 C.F.R.).

26912 U.S.C. $\S 1817(\mathrm{a})(12)$
} 
regulatory agencies further condensed the short-form Call Report by reducing the reporting frequency of $37 \%$ of the report's data items. ${ }^{270}$

While these reforms alleviate some burden on community banks, they also ignore the potential downsides of looser bank oversight. Numerous empirical studies have demonstrated that looser supervision leads to elevated risk-taking and more bank failures. One such study analyzed bank performance after Congress increased the eligibility threshold for the eighteen-month exam cycle to \$250 million in 1994 and \$500 million in 2006..$^{271}$ Exploiting these discontinuities, the authors concluded that banks experienced lower returns on equity and higher loan losses when they were subject to less frequent on-site examinations. ${ }^{272}$ Moreover, several studies have explored the effect on bank performance when supervisors move their offices away from a bank's headquarters - a proxy for less intense supervision. These studies conclude that a reduction in supervisory attention is associated with increased bank leverage, riskier investments, more bank failures, and higher resolution costs. ${ }^{273}$ The data therefore suggest that, when faced with lighter supervision, banks take more risks and are more prone to fail.

${ }^{270}$ Reduced Reporting for Covered Depository Institutions, 84 Fed. Reg. 29039, 29043 (June 21, 2019) (to be codified at scattered sections of 12 C.F.R.). The affected line items generally relate to riskweights for regulatory capital calculations, "fiduciary and related services assets and income, and troubled debt restructurings." See id.

${ }^{271}$ See Marcelo Rezende \& Jason J. Wu, The Effects of Supervision on Bank Performance: Evidence from Discontinuous Examination Frequencies 3 (Feb. 18, 2014) (unpublished manuscript), https://ssrn.com/a=2135017 [https://perma.cc/S3WZ-ZUQG].

${ }^{272}$ See id. at 19; see also Manthos D. Delis \& Panagiotis K. Staikouras, Supervisory Effectiveness and Bank Risk, 15 REV. FIN. 511, 512, 536 (2011) (finding that bank risk-taking is negatively correlated with the frequency of on-site examinations, based on a multicountry study); BEVERLY HIRTLE, ANNA Kovner \& Matthew Plosser, Fed. RsRv. Bank of N.Y., The Impact of SuPervision on Bank PERFORMANCE 2, 27-35 (2019), https://www.newyorkfed.org/medialibrary/media/research/staff_ reports/sr768.html [https://perma.cc/LQB5-XJ9X] (finding that banks receiving less supervisory attention hold riskier loan portfolios, are more volatile, and are more sensitive to economic shocks compared to other banks).

${ }^{273}$ See, e.g., John Kandrac \& Bernd Schlusche, The Effect of Bank Supervision on Risk Taking: Evidence from a Natural Experiment 1-3 (Jan. 15, 2019) (unpublished manuscript), https://ssrn.com/ $\mathrm{a}=2938039$ [https://perma.cc/48KU-YW5L] (concluding that when the Federal Home Loan Bank relocated supervisors away from Little Rock, Arkansas, institutions in the affected district increased risky real estate investments, grew more rapidly, were more likely to engage in accounting gimmicks, failed more frequently, and imposed higher costs on the deposit insurance fund); Yadav Gopalan, Ankit Kalda \& Asaf Manela, Hub-and-Spoke Regulation and Bank Leverage 2 (Jan. 2017) (unpublished manuscript), https://ssrn.com/a=2849877 [https://perma.cc/3EKX-9GS5] (finding that when the Office of the Comptroller of the Currency closes a field office, the banks nearest to the field office distribute more cash to shareholders, increase their leverage, and fail more frequently). 
With the recent wave of supervisory reforms, however, policymakers have effectively ignored these potential adverse consequences of looser community bank oversight. While reducing examination frequency and reporting requirements will lessen community banks' administrative burden, the trade-off will likely be increased societal costs in the form of excessive risk-taking and more frequent bank failures. Efforts to roll back community bank supervision are particularly troubling when combined with the deregulation of community bank capital, activities, and funding discussed above. And these regulatory and supervisory rollbacks are particularly illconceived just a decade after one of the worst too-many-to-fail crises in U.S. history.

\section{Weaker Corporate Governance}

In addition to permitting banks to invest in riskier assets, rely on more volatile funding, and avoid supervisory scrutiny, policymakers have also loosened restrictions on risk-seeking investors who may attempt to persuade community banks to adopt riskier strategies. For decades, federal law has restricted the level of control certain investors may exert over banks' decision-making. ${ }^{274}$ The Federal Reserve, however, has significantly relaxed those longstanding constraints. ${ }^{275}$ Newly enacted reforms to the Federal Reserve's "control rule" will permit hedge funds, private equity funds, and other outside investors to take bigger ownership interests in banks and exercise more influence over their managerial decisions.

Federal law establishes a regulatory framework governing certain bank shareholders. Specifically, the Bank Holding Company Act of 1956 provides that any company that "controls" a bank is a BHC and, accordingly, is subject to regulation and supervision by the Federal Reserve. ${ }^{276}$ This provision was designed "to ensure that companies that acquire control of banking organizations have the financial and managerial strength, integrity, and competence to exercise that control in a safe and sound manner." 277 Hedge funds, private equity funds, and similar outside investors, however,

\footnotetext{
274 See BARR ET AL., supra note 62, at 691-93.

275 See Control and Divestiture Proceedings, 85 Fed. Reg. 12398 (Mar. 2, 2020) (codified at scattered sections of 12 C.F.R.) [hereinafter Control Rule].

27612 U.S.C. $\S 1841(\mathrm{a})(1)$.

${ }^{277}$ Bd. of Governors of the Fed. Rsrv. Sys., Policy Statement on Equity Investments in Banks and Bank Holding Companies 2 (Sept. 22, 2008), https://www.federalreserve.gov/bcreg20080922b1.pdf [https://perma.cc/TR8F-FXE3].
} 
perceive $\mathrm{BHC}$ regulation as incompatible with their business models. ${ }^{278}$ As a result, these parties often try to structure their ownership stakes in banks as noncontrolling investments. ${ }^{279}$

The Bank Holding Company Act identifies three circumstances in which an investor is deemed to control a bank. Specifically, an investor controls a bank - and becomes a BHC - if it: (1) owns or has the power to vote $25 \%$ or more of any class of the bank's voting securities, (2) controls the election of a majority of the bank's board of directors, or (3) "directly or indirectly exercises a controlling influence over the management or policies of the bank." ${ }^{280}$ The first two criteria are relatively straightforward. The nebulous "controlling influence" prong, however, has engendered considerable uncertainty among potential investors who are unsure whether their ownership interests might constitute control. ${ }^{281}$

Traditionally, the Federal Reserve has assessed whether an investor exercises a controlling influence over a bank on a case-by-case basis. Among other factors, the Federal Reserve considers the size of the investor's ownership interest, the number of board seats the investor controls, and the investor's business relationships with the bank. ${ }^{282}$ The Federal Reserve generally evaluates these criteria on a sliding scale-investors with a comparatively high equity stake typically had to limit other indicia of control to avoid exercising a controlling influence. ${ }^{283}$ The Federal Reserve, however, has published few clear guidelines on which combinations of these factors would trigger control. Accordingly, a potential bank investor often seeks an ad hoc noncontrol determination - an assurance from the Federal Reserve that, based on the terms of a proposed investment, the investor will not be deemed to control the bank. ${ }^{284}$

${ }^{278}$ See John Coates \& David Scharfstein, Lowering the Cost of Bank Recapitalization, 26 YALE J. ON Reg. 373, 383-84 (2009); see also David L. Glass, So You Think You Want to Buy a Bank?, 73 AlB. L. REV. 447, 451 (2010) (discussing why private equity funds do not want to become BHCs).

279 See Thomas P. Vartanian, David L. Ansell \& Robert H. Ledig, The Bank Investor's SuRvival Guide: A GuIDE FOR Private EQUity, Hedge Fund, Mutual Fund \& ACTIVIST INVESTORS TO NAVIGATE U.S. FEDERAL BANK INVESTMENT RULES 6 (2016).

28012 U.S.C. $\S 1841(\mathrm{a})(2)$.

281 See VARTANIAN ET AL., supra note 279, at 27 ("Perhaps the most challenging and mysterious questions for investors and their legal advisors ... is whether a combination of stock ownership, board seats, business relationships and other affiliations with a [bank] equates to a "controlling influence'....").

${ }^{282}$ See id. at $27-31$.

${ }^{283}$ See id.

${ }^{284}$ See Letter from Randall D. Guynn, Davis Polk \& Wardwell LLP, to Ann E. Misback, Sec'y, Bd. of Governors of the Fed. Rsrv. Sys. 15 (July 15, 2019), https://www.federalreserve.gov/SECRS/ 2019/July/20190717/R-1662/R-1662_071519_134306_479985787863_1.pdf [https://perma.cc/S3S3- 
Banks and investors have criticized the Federal Reserve's ad hoc approach to control determinations on two grounds. First, they allege that the Federal Reserve's case-by-case precedent lacks transparency and consistency. As Federal Reserve Vice Chairman for Supervision Randal Quarles - a proponent of bank deregulation ${ }^{285}$ - has stated, "the practical determinants of when one company is deemed to control another are... ornate... and in some cases cannot be discovered except through supplication to someone who has spent a long apprenticeship in the art of Fed interpretation." ${ }^{286}$ Second, critics argue that the Federal Reserve has interpreted the BHC Act's control provisions too stringently, thereby discouraging investment. ${ }^{287}$ Community banks, in particular, have insisted that excessively strict control interpretations make it difficult for them to raise capital from investors that do not want to become BHCs. ${ }^{288}$

The Federal Reserve has responded to these criticisms by codifying its approach to control determinations. In early 2020, the Federal Reserve adopted a rule to "simplify and increase the transparency" of its control precedent. ${ }^{289}$ The rule establishes presumptions of control and noncontrol,

K4SX]. The Federal Reserve typically required an investor seeking a noncontrol determination to provide "passivity commitments" in which the investor would promise not to exercise or attempt to exercise a controlling influence over the bank. See VARTANIAN ET AL., supra note 279, at 33-34.

${ }^{285}$ See, e.g., Jeanna Smialek, Meet the Man Loosening Bank Regulation, One Detail at a Time, N.Y. Times (Nov. 29, 2019), https://www.nytimes.com/2019/11/29/business/economy/bank-regulationsfed.html [https://perma.cc/8D3H-XHBB].

${ }^{286}$ Randal K. Quarles, Vice Chairman for Supervision, Bd. of Governors of the Fed. Rsrv. Sys., Remarks at the American Bar Association Banking Law Committee Annual Meeting: Early Observations on Improving the Effectiveness of Post-Crisis Regulation 8 (Jan. 19, 2018), https://www.federalreserve.gov/newsevents/speech/files/quarles20180119a.pdf [https://perma.cc/5PZ6S8PS]; see also Guynn, supra note 284, at 15 ("This lack of transparency has produced both a lack of consistency and a lack of certainty.").

${ }^{287}$ See, e.g., Letter from Gregg Rozansky, Senior Vice President \& Senior Assoc. Gen. Counsel, Bank Pol'y Inst., to Bd. of Governors of the Fed. Rsrv. Sys. 8 (July 15, 2019), https://www.federalreserve.gov/SECRS/2019/July/20190717/R-1662/R-1662_071519_

134305_476700834744_1.pdf [https://perma.cc/E8S7-NZ5X] (“An overbroad view of the 'controlling influence' standard results in significant adverse consequences for . . . bank holding companies (including the ability of financially challenged and smaller banking organizations to raise capital) ....”).

${ }^{288}$ See Letter from Christopher Cole, Exec. Vice President \& Senior Regul. Counsel, Indep. Cmty. Bankers of Am., to Ann E. Misback, Sec'y, Bd. of Governors of the Fed. Rsrv. Sys. 2-3 (July 15, 2019), https://www.federalreserve.gov/SECRS/2019/July/20190717/R-1662/R-1662_071519_134339

527384436530_1.pdf[https://perma.cc/B73E-ULTV]; Control and Divestiture Proceedings, 85 Fed. Reg. 12398, 12400 (Mar. 2, 2020).

${ }^{289}$ Press Release, Bd. of Governors of the Fed. Rsrv. Sys., Federal Reserve Finalizes Rule to Simplify and Increase the Transparency of the Board's Rules for Determining Control of a Banking Organization (Jan. 30, 2020) [hereinafter Control Press Release], https://www.federalreserve.gov/newsevents/pressreleases/bcreg20200130a.htm [https:// perma.cc/3TYN-LL2P]. 
depending on an investor's equity ownership, number of board seats, and business relationships, among other factors. ${ }^{290}$ The Federal Reserve has explained that the presumptions are "generally consistent with [its] current practice" in making ad hoc control determinations. ${ }^{291}$ By codifying these presumptions, the Federal Reserve aims to make it "easier for banks, particularly community banks, to raise capital to support lending and investment." 292

Despite the Federal Reserve's claims, however, the control rule does not merely codify existing practice. Instead, the rule goes well beyond the Federal Reserve's precedent and allows private equity funds, hedge funds, and other investors to exert significantly more influence over community banks without being deemed in control. ${ }^{293}$ The rule's most significant liberalization allows a noncontrolling investor to appoint more members to a bank's board of directors. Traditionally, the Federal Reserve has limited a noncontrolling investor to one-or, in limited circumstances, two-director representative. ${ }^{294}$ By contrast, the new rule allows a noncontrolling investor to appoint up to one-quarter of a bank's board, or three directors for the average bank. ${ }^{295}$ In addition, the new rule relaxes constraints on a noncontrolling investor's representative chairing the bank's board of investors and permits a noncontrolling investor to have more significant

\footnotetext{
${ }^{290}$ See Control Rule, supra note 275, at 12401-12.

${ }^{291}$ See id. at 12401.

${ }^{292}$ Press Release, Bd. of Governors of the Fed. Rsrv. Sys., Federal Reserve Board Invites Public Comment on Proposal to Simplify and Increase the Transparency of Rules for Determining Control of a Banking Organization (Apr. 23, 2019) (quoting Federal Reserve Chair Jerome H. Powell), https://www.federalreserve.gov/newsevents/pressreleases/bcreg20190423a.htm [https://perma.cc/H43X-QBHF].

${ }^{293}$ Reviewing the new rule, law firm Wachtell, Lipton, Rosen \& Katz commented that "[b]eneficiaries of the rule include ... private equity" because "it is now possible for an investor to effect real change at a bank without being deemed to control it." Edward D. Herlihy \& Richard K. Kim, Financial Institution Developments, HARVARD L. SCH. F. ON CORP. GOVERNANCE (Feb. 17, 2020), https://corpgov.law.harvard.edu/2020/02/17/financial-institution-developments/ [https://perma.cc/ A7AX-ZPK6].

${ }^{294}$ See Control and Divestiture Proceedings, 84 Fed. Reg. 21634, 21639 (May 14, 2019) [hereinafter Control Proposal]. The Federal Reserve has allowed a noncontrolling investor to have two director representatives when: (1) there is another, larger shareholder that controls the bank, and (2) two director representatives represent a share of the bank's board that is proportional to the investor's voting interest in the bank. See id.

${ }^{295}$ See Control Rule, supra note 275, at 12402-03; see also BANK DiR., 2018 COMPENSATION SURVEY 22 (2018), https://www.bankdirector.com/wp-content/uploads/2018_Compensation_Survey.pdf [https://perma.cc/A9HG-F7DQ] (reporting that median board size is twelve members for banks with between $\$ 1$ billion and $\$ 5$ billion in assets). Further, the rule eliminates the requirement that there be another, larger shareholder that controls the bank in order for a noncontrolling investor to have more than one director representative. See Control Proposal, supra note 294, at 21639.
} 
business relationships with the bank. ${ }^{296}$ Although Federal Reserve Vice Chairman Randal Quarles has described these reforms as "a few targeted policy adjustments," 297 in practice, they could have a significant destabilizing effect on community bank corporate governance.

Allowing investors - particularly private equity firms and hedge funds - to exert more influence over community bank management is likely to increase risk-taking among small banks. Private equity firms and hedge funds often have higher risk preferences than typical community bank investors. ${ }^{298}$ And because less sophisticated directors often defer to more authoritative board members, private equity firm or hedge fund representatives could wield outsized influence in community bank boardrooms. ${ }^{299}$ Relaxing limits on noncontrolling investors' board representation will thus likely permit risk-prone institutional investors to steer community banks toward riskier strategies.

This intuition is consistent with empirical evidence that when a private equity firm takes an ownership stake in a financial company, the company increases its risk profile. As Professor Natasha Sarin and economist Divya Kirti have documented, after a private equity firm invests in an insurance company, the insurer immediately shifts its bond portfolio toward riskier assets. ${ }^{300}$ Sarin and Kirti show that private equity investors take advantage of loopholes in insurance capital rules to increase returns without assuming higher capital charges. ${ }^{301}$ Private equity investors could engage in similar

296 See Control Rule, supra note 275, at 12403 (discussing director representative service as chair of the bank's board); $i d$. at 12403-05 (establishing guidelines for business relationships).

297 See Randal K. Quarles, Vice Chair for Supervision, Bd. of Governors of the Fed. Rsrv. Sys., Opening Statement on Proposal to Revise the Board's Control Rules (Apr. 23, 2019), https://www.federalreserve.gov/newsevents/pressreleases/quarles-opening-statement-20190423.htm [https://perma.cc/8EUT-TP5F].

298 See FDIC COMMUNITY BANKING STUDY, supra note 6, at I ("Community banks tend to be ... characterized by local ownership, local control, and local decision making."); id. at 1-1 ("This means that community banks may weigh the competing interests of shareholders, customers, employees, and the local community differently from a larger institution with stronger ties to the capital markets.").

299 See Heidi K. Gardner \& Randall S. Peterson, Back Channels in the Boardroom, HARV. BuS. REV., Sept.-Oct. 2019, at 107, 113 (“Under pressure, groups tend to defer to people of higher status . . ..").

300 See Divya Kirti \& Natasha Sarin, Private Equity Value Creation in Finance: Evidence from Life Insurance 15-20 (Faculty Scholarship at Penn Law No. 2154, 2020), https://scholarship.law.upenn. edu/faculty_scholarship/2154 [https://perma.cc/VQ6N-REPM].

301 See id. at 3 ("Private equity-backed insurance firms are quick to increase asset risk without incurring any capital charges by substituting out of highly rated corporate bonds and into poorly rated private label asset-backed securities ....”). Similarly, Professor Robert DeYoung and colleagues have documented a significant jump in risk metrics at publicly traded commercial banks that received private equity investments between 2004 and 2016. See Robert DeYoung, Michal Kowalik \& Gokhan Torna, Private Equity Investment in U.S. Banks (Mar. 26, 2018) (unpublished manuscript), https://business.depaul.edu/about/centers-institutes/financial- 
behavior with community banks now that they are subject to fewer investment constraints. Efforts to weaken the Federal Reserve's control precedent are therefore particularly worrisome when combined with other community bank regulatory rollbacks. Private equity firms and hedge funds are uniquely apt to recognize new profit opportunities created by the community bank leverage ratio, the Volcker Rule exemption, and brokered deposit rules. ${ }^{302}$ Thus, newly empowered institutional investors are precisely the parties who are best positioned to exploit emerging weaknesses in community bank regulation.

In sum, the EGRRCPA and related deregulatory initiatives threaten to undermine community bank safety and soundness in several ways. These misguided reforms permit community banks to invest in riskier assets and use more volatile funding sources, while removing important supervisory oversight and allowing risk-prone investors to influence managerial decisions. Thus, if these reforms remain in place, they will enhance the probability and severity of another too-many-to-fail crisis. The next Part therefore recommends a novel regulatory approach to safeguard the community bank sector.

\section{THE FUTURE OF COMMUNITY BANK REGULATION}

This final Part recommends a new framework for community bank regulation in light of this Article's key insight that small banks can propagate systemic risk. Section IV.A contends that the overarching weakness of the current regulatory architecture is its two-tiered structure, which will increase financial instability by making the community bank sector a vehicle for regulatory arbitrage. Section IV.B reinforces why, due to those same concerns, the recent deregulatory movement should be halted and reversed. Finally, Section IV.C urges that, to the extent the current two-tiered system remains in place, policymakers should mitigate the destabilizing effects of

services/Documents/DeYoung\%20Kowalik\%20Torna.pdf [https://perma.cc/9NVY-DAF8]. The researchers observe a significant shift in the banks' asset portfolios toward volatile securities following a private equity investment and conclude that "consistent with the historically held concerns of bank regulators, private equity investment increased the risk profiles of commercial banking companies." Id. at 24 .

${ }^{302}$ Moreover, since institutional investors generally do not have close ties to a community bank's hometown, they may be less concerned than local community bank shareholders about the negative externalities of adopting riskier strategies. 
regulatory arbitrage through enhanced supervision of community banks. Specifically, it argues that two measures-heightened oversight of regulatory "cliff effects" and sector-wide community bank stress testswould help reduce the risk of another too-many-to-fail crisis.

\section{A. The Problem of Regulatory Arbitrage}

This Article's critique of postcrisis community bank regulation turns on the potential for regulatory arbitrage in the financial system, which is arguably the defining policy problem in all of banking law. ${ }^{303}$ Regulatory arbitrage can be understood as a consequence of the "boundary problem" that is inherent in every legal rule. ${ }^{304}$ By definition, every regulation includes a set of explicit or implicit boundaries that delineate the population of firms or activities to which it applies. ${ }^{305}$ These boundaries introduce a challenge for financial regulation because, even if a new restriction successfully reduces risk-taking by a certain subset of banks in the first instance, it also increases the returns from similar forms of financial intermediation conducted outside the regulatory perimeter. Thus, the catch- 22 that accompanies any financial regulation is that the more it proves effective, the more it encourages financial activity to flow across legal boundaries from the well-regulated sector to the less-regulated sector.

Although the regulatory arbitrage problem occurs to some degree in every area of the law, the dilemmas it presents are particularly acute with respect to the banking system due to the unique flexibility of financial activity, which can be legally repackaged to cross regulatory boundaries with

303 See generally Matthew C. Turk, The Convergence of Insurance with Banking and Securities Industries, and the Limits of Regulatory Arbitrage in Finance, 2015 COLUM. BuS. L. REV. 967 (discussing regulatory arbitrage in the financial sector).

${ }^{304}$ See Charles Goodhart, The Boundary Problem in Financial Regulation, 206 NAT'L INST. ECON. Rev. 48, 48-50 (2008); see also MARKus BrunNermeIER, ANDrEW CROCKET, CHARLES GoOdHART, Avinash D. Persaud \& Hyun Shin, The Fundamental Principles of Financial Regulation 69 (2009).

${ }^{305}$ Most often, these boundaries are explicit. For example, when the financial regulators issued their Dodd-Frank risk-retention rules for mortgage-backed securitizations, they exempted loans that are designated as "Qualified Residential Mortgages." See Credit Risk Retention, 79 Fed. Reg. 77602 (Dec. $24,2014)$. When the CFPB promulgated its mortgage-underwriting rules in connection with $\S 1411$ of Dodd-Frank, known as "Regulation Z," it included a carve out for "Qualified Mortgages," defined somewhat differently from "Qualified Residential Mortgages." See 12 C.F.R. § 1026.43(e); Dodd-Frank Act, Pub. L. No. 111-203, § 1411, 124 Stat. 1376, 2142 (2010) (codified at 15 U.S.C. § 1639); see also David Reiss, Message in a Mortgage: What Dodd-Frank's "Qualified Mortgage" Tells Us About Ourselves, 31 REV. BANKING \& FIN. L. 717, 721-24 (2012) (reviewing the development of regulations that draw a line between "qualified" and "nonqualifying" home mortgages for purposes of certain regulatory exemptions). 
remarkable ease. ${ }^{306}$ One classic example is an FDIC rule from the 1980s, known as Regulation Q, which placed a ceiling on the interest rate that commercial banks could offer depositors. ${ }^{307}$ Soon after that ceiling was imposed, money market mutual funds and other entities that did not qualify as commercial banks quickly emerged to provide deposit-like services, and the now-infamous "shadow banking sector" was born. ${ }^{308}$ Another dramatic illustration is the market for "364-day repo" contracts, which arose following changes to the international Basel Accords that attempted to push banks toward assets with a maturity of less than one year. ${ }^{309}$

These episodes present a cautionary tale for postcrisis reforms, which have created a two-tiered system that sorts financial institutions according to their size. ${ }^{310}$ Dodd-Frank's primary aim was to formulate an elaborate constellation of new restrictions for the largest too-big-to-fail financial institutions, while leaving the precrisis rules for smaller banks more or less intact. ${ }^{311}$ The EGRRCPA exacerbated this disparity by further relaxing rules for community banks. ${ }^{312}$ A doubly perverse outcome can be anticipated to follow: any regulatory boundary premised on a size threshold will expand the market share of banks below that threshold, while also making those banks less stable. In other words, to the extent that postcrisis rules meet their goal of safeguarding a subset of too-big-to-fail institutions, they simultaneously drive risk-taking toward smaller banks and thereby make another too-many-to-fail crisis more likely.

Although the most serious consequences of EGRRCPA-induced regulatory arbitrage will not be felt until well after the Act's implementation, recent research suggests that financial risk-taking has already begun to

306 See Thomas W. Merrill, A Comment on Metzger and Zaring: The Quicksilver Problem, 78 LAW \& CONTEMP. PROBS. 189, 189-92 (2015) (noting the quicksilver-like flexibility of financial activities with respect to regulatory boundaries); Turk, supra note 303, at 1061.

307 See ADMATI \& Hellwig, supra note 190, at 53, 251 n.26, 299 n.46 (analyzing Regulation Q and its role in the rise of shadow banking). For a general discussion of the implementation and subsequent fading out of Regulation Q, see R. Alton Gilbert, Requiem for Regulation Q: What It Did and Why It Passed Away, 68 Fed. RSRV. BAnK ST. Louis REV. 22 (1986).

308 See AdMATi \& HELlWIG, supra note 190, at 53-54.

309 See Viral V. Acharya, The Dodd-Frank Act and Basel III: Intentions, Unintended Consequences, Transition Risks, and Lessons for India 18 (Int'l Growth Ctr., Working Paper No. 18, 2011).

310 See supra Section II.A. In reality, the postcrisis regulatory landscape is even more gradated, with additional levels of regulation kicking in for firms with $\$ 250$ billion and $\$ 700$ billion in assets, and for those designated as global systemically important banks. See Changes to Applicability Thresholds for Regulatory Capital and Liquidity Requirements, 84 Fed. Reg. 59230, 59231, 59244 (Nov. 1, 2019) (codified in scattered sections of 12 C.F.R.). The most significant and far-reaching boundary problem, however, occurs at the $\$ 10$ billion threshold that separates community banks from noncommunity banks.

311 See supra Section II.A.

312 See supra Section III. 
migrate to community banks. For example, one recent econometric study concludes that, as a result of Dodd-Frank's stress tests, the market for relatively risky business loans has shifted away from large banks subject to the tests and toward community banks, which are not. ${ }^{313}$ Related research has also found that, due to this risk migration, small banks would be unable to pass stress tests equivalent to those required of larger banks. ${ }^{314}$ Significantly, this research does not find that small banks would struggle due to the compliance costs of administering the stress tests, or suggest that those tests have been tailored to large-bank balance sheets and are therefore a poor fit for the business model of small banks. ${ }^{315}$ Rather, the primary factor is that community bank asset portfolios have started to absorb riskier loans. ${ }^{316}$ Thus, in keeping with the simple logic of regulatory arbitrage, risks have already begun migrating to the community bank sector, with this dynamic likely to accelerate once the EGRRCPA's provisions are fully implemented.

There is yet another strong indicator that postcrisis reforms have encouraged regulatory arbitrage: banks are "bunching"-or strategically manipulating their asset sizes - just below regulatory size thresholds. ${ }^{317}$ The starkest bunching effect has occurred just below the $\$ 10$ billion asset mark at which many community bank exemptions phase out. For the 2003 to 2006 period-when the $\$ 10$ billion asset threshold had negligible regulatory significance - the number of institutions with assets slightly below $\$ 10$ billion outnumbered banks with assets slightly above $\$ 10$ billion by about $20 \%{ }^{318}$ But by the 2015 to 2017 period — when Dodd-Frank began shielding community banks from certain regulatory burdens - there were more than three times as many banks hovering just below the $\$ 10$ billion threshold as

${ }^{313}$ See Cortés et al., supra note 29, at 30-34; cf. Francisco Covas, Capital Requirements in Supervisory Stress Tests and Their Adverse Impact on Small Business Lending 28-30 (The Clearing House, Working Paper No. 2017-2, 2017) (demonstrating that the stress test reduces credit availability and loan growth). For a discussion of regulatory capital arbitrage, see generally Erik F. Gerding, The Dialectics of Bank Capital: Regulation and Regulatory Capital Arbitrage, 55 WASHBURN L.J. 357, 358 (2016).

314 See Bill Nelson \& Francisco Covas, How Would Banks that Concentrate in Main Street Lending Fare in the Fed's CCAR Stress Test?, BANK POL'Y INST. (Oct. 4, 2018), https://bpi.com/how-wouldbanks-that-concentrate-in-main-street-lending-fare-in-the-feds-ccar-stress-test/ [https://perma.cc/9CEZEXZ9] (estimating that approximately one-fifth of banks with less than $\$ 10$ billion in assets would have failed the 2018 stress tests).

315 See id.

316 See id.

317 See Mukharlyamov \& Sarin, supra note 30, at 25-27 (discussing the bunching phenomenon).

318 David Hou \& Missaka Warusawitharana, Effects of Fixed Nominal Thresholds for Enhanced Supervision, FEDS NOTES (July 19, 2018), https://www.federalreserve.gov/econres/notes/fedsnotes/effects-of-fixed-nominal-thresholds-for-enhanced-supervision-20180719.htm $\quad$ [https://perma.cc/ 7FUT-9T2F]. 
there were institutions slightly above it. ${ }^{319}$ Anecdotal accounts from industry participants often attribute this bunching dynamic to the regulatory "pain" that banks expect to encounter when crossing key size thresholds, which incentivizes them to restrict lending growth for legal-compliance reasons, rather than any business or economic rationale. ${ }^{320}$ Research by financial economists also concludes that similar considerations have prevented community banks from pursuing otherwise attractive acquisition opportunities in order to keep their total assets below $\$ 10$ billion. ${ }^{321}$ Banks, in sum, are engaging in regulatory arbitrage by clustering below asset thresholds that shield them from adverse legal treatment.

Taken together, this pair of emerging patterns - risk migration and institutional bunching - can be visualized as a kind of "cliff effect." As researchers at the Federal Reserve have observed, these regulatory cliff effects are triggered by the "discontinuous increase in regulatory burdens as [banks] cross the[] fixed nominal asset thresholds" that permeate postcrisis reforms. ${ }^{322}$ Because nominal size thresholds draw an inherently arbitrary bright line between institutions on either side, financial activities - and their attendant risks - have begun to flow over those regulatory cliffs and cluster just short of where heightened legal restrictions kick in. As this Article has

319 See id. The same trend has also occurred to a lesser extent at the $\$ 50$ billion threshold, where a number of significant postcrisis rules kick in as well. See id.; see also Christina Rexrode \& Ryan Tracy, The \$50 Billion Question: What Makes a Bank Big?, WALl ST. J. (May 30, 2017, 5:30 AM), https:/www.wsj.com/articles/the-50-billion-question-what-makes-a-bank-big-1496136650 [https:// perma.cc/YH94-GFV9] (discussing the debate over regulatory size thresholds which target banks with $\$ 50$ billion in assets or more).

320 See Robert Barba, Crossing the \$10B Threshold Is Painful, Acquirers Say, AM. BANKER (Sept. 17, 2014, 5:27 PM), https:/www.americanbanker.com/news/crossing-the-10b-threshold-is-painfulacquirers-say [https://perma.cc/3SUA-K9PG]; Pain Ahead: Crossing the $\$ 10$ Billion Threshold, STRATEGIC RES. MGMT., https://www.srmcorp.com/pdfs/13/fact_sheet_approaching_10_billion.pdf [https://perma.cc/HC6W-FVA6]; Susan Thomas Springer, What Happens When a Bank Hits \$10 Billion?, INDEP. BANKER (Feb. 27, 2017), https://independentbanker.org/2017/02/what-happens-when-abank-hits-10-billion [https://perma.cc/4LRZ-4DE8]; Patty Tascarella, The \$10B Dilemma: As Banks Near This Amount in Assets, Many Don't Want to Cross the Line, PitTsBurgh Bus. Times (Sept. 21, 2016, 2:34 PM), https:/www.bizjournals.com/pittsburgh/news/2016/09/21/the-10b-dilemma-as-banksnear-this-amount.html [https://perma.cc/MH46-GUPW].

321 For banks approaching the $\$ 10$ billion asset threshold, the average size of mergers and acquisitions has increased considerably in recent years. This finding suggests that banks have forgone otherwise attractive acquisition opportunities unless the target bank would increase the bank's size sufficiently to justify the increased regulatory costs. See Hailey Ballew, Michael Iselin \& Allison Nicoletti, Regulatory Asset Thresholds and Acquisition Activity in the Banking Industry 18-28 (June 16, 2017) (unpublished manuscript), https://www.communitybanking.org/ /media/files/communitybanking/2017/session2_ paper3_nicoletti.pdf [https://perma.cc/R9M8-WRHT]; Allison Nicoletti, Michael Iselin \& Hailey Ballew, Bright Lines: How Regulatory Asset Thresholds Change the Banking Industry, 6 PENN. Wharton Pub. Pol'y Initiative 1, 4 (2018).

322 See Hou \& Warusawitharana, supra note 318. 
argued, the $\$ 10$ billion cutoff used to define community banks and determine their regulatory treatment is now the most salient regulatory threshold.

Thus, a central challenge for community bank regulation going forward is to police the distortions created by regulatory arbitrage of the $\$ 10$ billion ceiling. To that end, the next two Sections recommend that policymakers address these distortions by: (1) halting and reversing the EGRRCPA and related deregulatory initiatives, and (2) closely supervising community banks, with an emphasis on those approaching regulatory asset thresholds.

\section{B. Recommendation \#1: Reverse Recent Deregulatory Reforms}

The most straightforward way to mitigate the "cliff effect" dynamics outlined above would be to undo the EGGRCPA provisions that provide unduly favorable regulatory treatment to community banks. As described in Part III, the EGGRCPA and related deregulatory initiatives encourage community banks to substantially increase their risk profiles. Therefore, the best strategy to prevent the predictable escalation of risk in the community bank sector is to repeal the EGGRCPA's deregulatory provisions.

To be sure, repealing the EGGRCPA will be politically difficult. As discussed above, community banks wield outsized power in Congress. ${ }^{323}$ And given the bipartisan support EGGRCPA received, mere shifts in party control within Congress will not be sufficient to undo the law. ${ }^{324}$ In the most likely scenario, Congress will not reregulate community banks until too late, after the next too-many-to-fail crisis. ${ }^{325}$ But proactive-rather than reactive-legislation would be far preferable to safeguard the community bank sector from oncoming risks.

Even if Congress does not act, however, the federal regulatory agencies can address some emerging risks through the administrative rulemaking process, which may be more politically feasible. The EGRRCPA, for

\footnotetext{
323 See supra note 98 and accompanying text. As one observer commented, "For both Democrats and Republicans, supporting community banks is an easy decision. Local banks exist in every congressional jurisdiction and have built trust with local communities. Being on the wrong side of community banks can have serious consequences for politicians." Konczal, supra note 98.

324 The EGRRCPA was supported by fifty out of fifty voting Republicans and sixteen of forty-six voting Democrats in the Senate. Roll Call Vote 115th Congress-2nd Session, U.S. SENATE, https://www.senate.gov/legislative/LIS/roll_call_lists/roll_call_vote_cfm.cfm?congress $=115 \&$ session $=2$ $\&$ vote $=00054$ [https:/perma.cc/MUB9-LG2K]. It was supported by 225 of 226 voting Republicans and 33 of 191 voting Democrats in the House of Representatives. Final Vote Results for Roll Call 216, OFF. OF THE CLERK OF THE U.S. HOUSE OF REPRESENTATIVES, http://clerk.house.gov/evs/2018/roll216.xml [https://perma.cc/3CTK-925L].

325 See generally Jihad Dagher, Regulatory Cycles: Revisiting the Political Economy of Financial Crises (Int'1 Monetary Fund, Working Paper No. 18/8, 2018) (describing the cycle of crisis-regulationderegulation-crisis in financial markets).
} 
example, authorizes the federal banking agencies to set the CBLR between $8 \%$ and $10 \% .{ }^{326}$ Although the agencies initially fixed the leverage ratio at $9 \%,{ }^{327}$ they could increase the leverage requirement to $10 \%$ to ensure that community banks maintain a bigger capital cushion against potential losses. Moreover, the FDIC should refrain from adopting its proposal to loosen restrictions on brokered deposits, which is not required by statute. ${ }^{328}$ And the agencies, of course, retain broad discretion to enact other prudential safeguards - such as liquidity requirements, risk-management standards, or credit-concentration limits - to prevent excessive risk-taking by community banks. $^{329}$ Thus, while legislative repeal of the EGRRCPA would be the optimal response to the too-many-to-fail problem, the regulatory agencies can address some emerging risks on their own.

\section{Recommendation \#2: Strengthen Community Bank Oversight}

Even if the EGRRCPA were reversed in full, the United States' twotiered regulatory structure would nonetheless remain intact-albeit to a lesser extent-due to exemptions in Dodd-Frank that shield community banks from the most meaningful postcrisis reforms. ${ }^{330}$ So too would the opportunities for regulatory arbitrage that are facilitated under such a structure. It is therefore imperative that the regulatory architecture incorporate some affirmative measures to prevent the arbitrage of size thresholds from destabilizing the community bank sector.

This Section proposes two supervisory reforms that would mitigate the risks of such cliff effects, whether or not Congress were to repeal the EGRRCPA. In general, the financial regulatory agencies use two oversight techniques: firm-specific microprudential supervision and sector-wide macroprudential surveillance. ${ }^{331}$ At the firm-specific level, the financial regulatory agencies should enhance microprudential supervision by focusing their attention on community banks approaching the $\$ 10$ billion regulatory "cliff." At the same time, the financial regulatory agencies should implement a macroprudential approach to community bank supervision by establishing sector-wide stress tests to detect escalating risks among smaller banks. These

\footnotetext{
326 See supra note 203 and accompanying text.

327 See supra note 205 and accompanying text.

328 See supra Section III.B.

329 See, e.g., 12 U.S.C. $\S 1831 \mathrm{p}-1$ (directing the federal banking agencies to establish safety-andsoundness standards).

330 See supra Section II.A

331 See generally David Aikman, Jonathan Bridges, Anil Kashyap \& Caspar Siegert, Would Macroprudential Regulation Have Prevented the Last Crisis?, 33 J. ECON. Persps. 107 (2019) (explaining the distinction between microprudential and macroprudential financial regulation).
} 
supervisory reforms would work in conjunction to offset the risks of regulatory arbitrage that are endemic to the two-tiered legal structure of postcrisis financial regulation.

\section{Enhance Supervision of Regulatory "Cliff Effects"}

First, the financial regulatory agencies should use microprudential mechanisms to deter the buildup of risk near regulatory "cliffs." Microprudential oversight is the most traditional form of bank supervision, involving regular safety-and-soundness examinations of individual firms. ${ }^{332}$ Because the EGRRCPA constrains microprudential supervision of certain community banks, ${ }^{333}$ it is increasingly important for the financial regulatory agencies to use their remaining supervisory authority to effectively identify risks.

The agencies' microprudential supervision framework is generally well designed to deter regulatory arbitrage. When performing safety-andsoundness exams, the agencies evaluate individual banks on six metrics that comprise the so-called CAMELS rating system: (C)apital, (A)ssets, (M)anagement, (E)arnings, (L)iquidity, and (S)ensitivity to market risk. ${ }^{334}$ The agencies assign a bank a rating of one to five on each metric - with one meaning "strong" and five meaning "critically deficient"-plus an overall "composite" score. ${ }^{335}$ Ratings downgrades can lead to various regulatory penalties for a bank, including prohibitions on mergers and acquisitions, restrictions on activities, and limitations on opening new branches. ${ }^{336}$ As a result, banks try to maintain strong CAMELS ratings.

In response to the EGRRCPA's ill-advised regulatory rollbacks, the banking agencies should use their microprudential supervisory authority to deter firms from engaging in regulatory arbitrage. Safety-and-soundness examinations have always been understood as an open-ended, qualitative process, and regulators wield ample legal authority to address those

${ }_{332}$ See, e.g., Daniel K. Tarullo, Macroprudential Regulation, 31 YALE J. ON REG. 505, 510 (2014).

333 See supra Section III.C.

${ }^{334}$ See Uniform Financial Institutions Rating System, 62 Fed. Reg. 752, $752-53$ (Jan. 6, 1997) (providing an overview of the CAMELS rating system); see also John Crawford, Predicting Failure, 7 VA. L. \& BUS. REV. 171, 197-98 (2012) (exploring how the CAMELS approach to bank examinations operates in practice).

${ }^{335}$ Uniform Financial Institutions Rating System, supra note 334, at 753.

336 See, e.g., Letter from Michael S. Gibson, Dir. of the Div. of Banking Supervision \& Regul. \& Tonda Price, Deputy Dir. of the Div. of Consumer \& Cmty. Affs., to the Off. in Charge at Each Fed. Rsrv. Bank \& Fin. Insts. Supervised by the Fed. Rsrv. (Feb. 24, 2014), https://www.federalreserve.gov/ supervisionreg/srletters/sr1402.htm [https://perma.cc/6493-7XXC]. 
concerns. ${ }^{337}$ For example, the agencies could use the "Assets" and "Liquidity" criteria to focus on the migration of relatively high-risk loans or funding sources across the regulatory cliff that separates community banks from mid-sized institutions. Likewise, the agencies could broaden the "Sensitivity" criterion to account for a wider range of market risks, especially to the extent that firms close to the $\$ 10$ billion cliff increase their risk tolerance in light of their exemption from the Volcker Rule. ${ }^{338}$ Downgrading banks that escalate their risk profiles in response to the EGRRCPA would at least somewhat offset the regulatory arbitrage problem. Moreover, these supervisory reforms focused on regulatory cliff effects would be largely consistent with the agencies' traditional microprudential practice.

Thus, notwithstanding the EGGRCPA's regulatory rollbacks, the agencies can help mitigate risks in the community bank sector by emphasizing microprudential supervision of banks approaching regulatory cliffs. While Congress undid many important safeguards, the agencies retain discretion to penalize excessively risky banks through the supervisory process. Enhancing microprudential supervision of firms near regulatory cliffs may therefore be the agencies' most flexible response to the regulatory arbitrage problem.

\section{Stress Test the Community Bank Sector}

Macroprudential supervision of community banks should be a critical supplement to traditional safety-and-soundness examinations at individual institutions. ${ }^{339}$ The real threat to financial stability is not that any particular small bank might attempt to manipulate postcrisis regulatory size thresholds. Rather, it is the possibility for a wholesale leakage of financial risk-taking across the $\$ 10$ billion boundary, which in turn could imperil numerous community banks at the same time. Since the 2008 financial crisis, macroprudential supervision has focused exclusively on "too-big-to-fail" banks. $^{340}$ In light of the regulatory-arbitrage phenomenon, however, the

337 See Menand, supra note 255, at 65-69 (discussing supervisory agencies' broad legal authority to address "unsafe and unsound" practices).

${ }^{338}$ As of now, the agencies' sensitivity analysis focuses on a narrower band of market risks, primarily the risk that community banks are vulnerable to interest-rate fluctuations. See Uniform Financial Institutions Rating System, supra note 334, at 756.

339 Macroprudential supervision aims to detect and prevent risks to the broader financial system, rather than to an institution in isolation. See Dirk Schoenmaker \& Peter Wierts, Macroprudential Supervision: From Theory to Policy 4 (Eur. Systemic Risk Bd. Working Paper No. 2, 2016), https://www.esrb.europa.eu/pub/pdf/wp/esrbwp2.en.pdf [https://perma.cc/3C7F-8L49].

${ }^{340}$ See, e.g., Lev Menand, Too Big to Supervise: The Rise of Financial Conglomerates and the Decline of Discretionary Oversight in Banking, 103 CORNELL L. REv. 1527, 1574 (2018). 
federal banking agencies should use their existing legal authorities to conduct macroprudential supervision of the community bank sector as well.

While bank supervision has traditionally focused on microprudential strategies, postcrisis reforms introduced a macroprudential approach for the largest financial institutions. For example, Dodd-Frank centralized macrosurveillance of the financial sector in the Financial Stability Oversight Council (FSOC), an umbrella agency designed to coordinate the monitoring of systemic risk. ${ }^{341}$ Moreover, Dodd-Frank established annual Federal Reserve stress tests for the largest bank holding companies, designed to detect the largest banks' systemic vulnerabilities to macroeconomic and financial shocks. ${ }^{342}$ To date, however, this macroprudential approach to bank supervision has overlooked potential systemic risks among community banks.

Thus, as a natural extension of postcrisis macroprudential supervision, the FSOC and the federal banking agencies should assess whether the cliff effects introduced by postcrisis policy changes are accelerating in a way that undermines the stability of the community bank sector as a whole. As a starting point, the banking agencies could analyze aggregate data drawn from Call Reports submitted by individual community banks, with an eye toward spotting industry-wide trends that reflect arbitrage of the $\$ 10$ billion size boundary. More ambitiously, the banking agencies could use the same data to perform nonbinding stress tests of the small banking sector to evaluate whether community banks in general are resilient to adverse macroeconomic conditions or shocks to other parts of the financial system. ${ }^{343}$ While small banks are exempt from Dodd-Frank's firm-specific stress tests, sector-wide stress tests would enable the banking agencies to monitor aggregate risks among community banks. The results of such sector-wide stress tests could then inform the agencies' microprudential supervisory priorities.

In short, while macroprudential supervision is typically thought of as a response to the too-big-to-fail problem, it can also help alleviate the toomany-to-fail issue. FSOC and the banking agencies should respond to

${ }^{341}$ Dodd-Frank Act, Pub. L. No. 111-203, § 111, 124 Stat. 1376, 1392 (2010) (codified at 12 U.S.C. $\S 5321$ ) (establishing the FSOC); see also Hilary J. Allen, Putting the "Financial Stability" in the Financial Stability Oversight Council, 76 Оніо ST. L.J. 1087, 1113-19 (2015) (explaining the FSOC's main functions).

${ }^{342}$ Dodd-Frank Act $\S 165(i)(1)$ (codified at 12 U.S.C. $\S 5365$ ). For background on the Federal Reserve's stress tests, see Mehrsa Baradaran, Regulation by Hypothetical, 67 VAND. L. REV. 1247, $1283-$ 94 (2014), Matthew C. Turk, supra note 105, at 1713-15, and Robert Weber, A Theory for DeliberationOriented Stress Testing Regulation, 98 MinN. L. Rev. 2236, 2291-94 (2014).

343 In contrast to Dodd-Frank's firm-specific stress tests, nonbinding community bank sector-wide stress tests would not automatically require individual community banks to suspend capital distributions or raise additional capital. Rather, the FSOC and the banking agencies would conduct these stress tests in an advisory capacity to help inform their supervisory priorities. 
escalating systemic risks among community banks by monitoring aggregate exposures, including through sector-wide stress tests. This macroprudential approach would be appropriate in light of community banks' underappreciated systemic importance.

\section{CONCLUSION}

The too-many-to-fail phenomenon is the most persistent and underappreciated pattern in U.S. banking history. It is not difficult, therefore, to envision the next community bank crisis on the horizon. Both historical experience and basic economic theory teach that the too-many-to-fail phenomenon is likely to recur and should thus be an ongoing, central focus of U.S. financial regulation. Despite this intuition, however, policymakers suffering from collective amnesia have implemented policies that make the next too-many-to-fail crisis more likely. Financial regulatory scholars, meanwhile, have unwisely welcomed these reforms.

This Article has demonstrated that the conceptual justifications for community bank deregulation are deeply flawed. Contrary to popular perception, the community bank sector is often systemically important. Moreover, postcrisis regulatory reforms did not excessively burden community banks, and community banks can continue to fulfill their relational-lending niche without special subsidies or deregulation.

This Article has attempted to expose these long-held myths, perpetuated by the community-bank lobby and its allies. The Article has argued that the EGRRCPA and related regulatory rollbacks unwisely increase risks in the community bank sector and encourage regulatory arbitrage. And it has proposed a comprehensive framework to safeguard community banks in the future. At the very least, this Article aimed to change the deeply flawed conventional wisdom about community banks. With a proper understanding of community banks' potential systemic risks, policymakers should take the necessary steps to address the too-many-to-fail problem. 